UNIVERSIDADE DE SÃO PAULO

ESCOLA DE COMUNICAÇÃO E ARTES

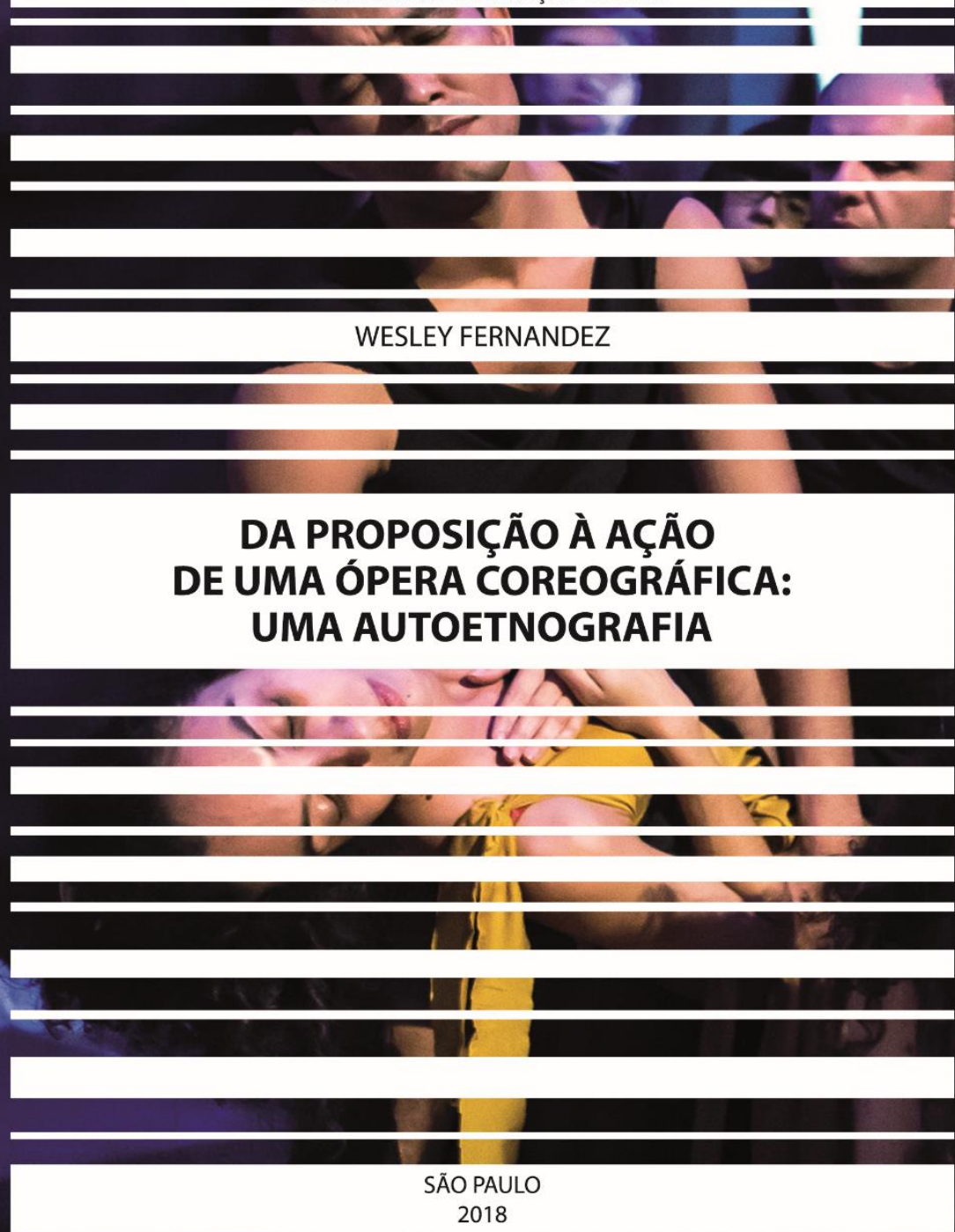

2018 


\title{
WESLEY FERNANDEZ
}

\section{Da proposição à ação de uma ópera coreográfica: uma autoetnografia.}

\begin{abstract}
Dissertação apresentada ao Programa de Pós-Graduação em Artes Cênicas da Escola de Comunicações e Artes da Universidade de São Paulo, para obtenção do título de mestre em Artes Cênicas.
\end{abstract}

\section{Área de Concentração Teoria e Prática do Teatro}

Orientadora Profa. Dra. Sayonara Sousa Pereira

São Paulo

2018 



\section{Nome: FERNANDEZ, Wesley}

Título: Da proposição à ação de uma ópera coreográfica: uma autoetnografia.

Dissertação apresentada ao Programa de PósGraduação em Artes Cênicas da Escola de Comunicações e Artes da Universidade de São Paulo, para obtenção do título de mestre em Artes Cênicas.

Aprovado em:

\section{BANCA EXAMINADORA}

Profa. Dra. Sayonara Sousa Pereira Instituição: ECA/USP 
Prof.(a) Dr.(a)

Instituição:

Prof.(a) Dr.(a)

Instituição: 


\section{Dedicatória}

Para todos os integrantes do NUO-Ópera Laboratório, pois sem eles essa autoetnografia não existiria.

Especialmente para Nilo Maria Leal Filho, pelo apoio em todas as horas e em todos os sentidos, que inclusive é o designer da capa desta dissertação. Meu mais sincero OBRIGADO para além disso. 


\section{Agradecimentos}

À minha orientadora Profa. Dra. Sayonara Pereira, pela oportunidade, paciência e por acreditar na arte dentro da academia.

À Profa. Dra. Marília Velardi que além de aceitar participar da banca de qualificação desta pesquisa, acreditou que eu poderia chegar até aqui quando eu mesmo nem sabia que seria capaz.

À Dra. Vanessa Macedo por ter aceitado o convite de participar da banca de qualificação e contribuir com esse trabalho de forma generosa.

Ao Prof. Dr. Paulo Maron, diretor do NUO-Ópera Laboratório pela coragem de criar, manter e inspirar esse grupo, que eu tenho a honra de fazer parte e o lugar que posso ser eu mesmo.

À André Estevez, Andrezza Reis, Angélica Menezes, Eliane Gama, Marília Velardi, Paulo Maron, Pedro Ometto, Renata Matsuo, Yuri Basichetto Tambucci, parceiros de vida, pela coautoria deste texto.

Ao ECOAR, por estarem presentes sempre, desde a graduação. No ECOAR aprendi a estudar, ouvir e ser ouvido. 
Aos colegas do LAPETT, pelas trocas e contribuições.

Às funcionárias e funcionários da Escola de Comunicações e Artes da USP.

Ao Studio Lorena Hair e Spa, pela oportunidade de emprego e apoio financeiro neste momento da vida.

Às minhas professoras e professores de dança ao longo da vida.

Aos meus alunos pelos afetos e trocas.

Aos meu amados pais, Alice e Bruno pela liberdade de ser quem eu sou.

À minha irmã, dessa e de outras vidas, Claudia, meu irmão/cunhado Walmir e meu sobrinho Mathieus, meu sincero obrigado por me incentivarem a estudar e ser um ser humano melhor. Amo vocês.

À Andrea Salgueiro, amiga de todas as horas e incentivadora. Ao Luciano por ter cedido as fotos gentilmente.

À Denise, terapeuta amada por me dar sustentação emocional antes, durante e com certeza depois desse período. 
À Silvana por ter me ajudado com a revisão do texto.

Ao Thiago pela revisão do resumo em inglês.

À todas as pessoas do meu cotidiano.

A você que está lendo este trabalho agora.

À minha espiritualidade que sempre me ampara e me impulsiona a ser o melhor que eu possa ser nessa vida. 


\section{Resumo:}

Fernandez, Wesley. Da proposição à ação de uma ópera coreográfica: uma autoetnografia. São Paulo, 2018, 248 p.:

il. Dissertação (Mestrado) - Programa de Pós-Graduação em Artes Cênicas - Escola de Comunicações e Artes, Universidade de São Paulo, 2018.

Este trabalho apresenta uma autoetnografia em diálogo com os artistas que participaram da ópera coreográfica: "Aniversário e Morte de Queen Mary II", no NUO-Ópera Laboratório. Portanto, o objetivo desta investigação é descrever, narrar, contextualizar e situar o processo desta obra concebida especialmente para o NUO-Ópera Lab. Faremos isso, a partir das memórias dos artistas, que participaram, e de material audiovisual, trazendo as falas dos autores integrantes do NUO-Ópera Lab. que não são narradores/depoentes/produtores de dados/interlocutores da pesquisa, mas, assinam a autoria desse trabalho conosco. Os processos práticos/reflexivos desta obra artística e deste texto nos levam a acreditar que a ópera tem várias camadas. E são nessas muitas camadas que a riqueza da ópera habita. Não é nem o texto, nem a música, nem a dança, mas sim, a ação que está nesta amálgama. A ópera é o teatro da ação, na perspectiva do transgênero. Passamos a entender o que é 
ópera e como se dá a direção em ópera, através do processo transdisciplinar que acontece no NUO-Ópera Lab. Esse processo como um todo, artístico reflexivo, proporcionou turning points pessoais, ou seja, cada integrante envolvido no processo achou insights pessoais, dando sentidos e significados próprios; e turning points grupais, coisas que foram mais gerais e coletivas.

Termos-chave: autoetnografia; ópera coreográfica ópera; teatro; dança. 


\section{Abstract}

Fernandez, Wesley. From the proposition to the action of an opera choreographic: an autoethnography. São Paulo, 2018, 248 p.: il. Dissertação (Mestrado) - Programa de PósGraduação em Artes Cênicas - Escola de Comunicações e Artes, Universidade de São Paulo, 2018.

This Masters work introduces an autoethnography in connection to all artists who have participated on the opera choreography entitled "Anniversary and Death of Queen Mary II", which was performed at NUO-Opera Laboratory. Therefore, the aim of this research is to describe, narrate, contextualize and situate the process under the aforementioned opera work especially developed to NUOOpera Lab. Herein, we will achieve this objective by bringing artists memories who were part of the personnel in the play and all audiovisual material enlightening all the author's lines who belonged to NUO-Opera Lab, who were not narrators / deponents / data producers / research interlocutors, but who share the authorship of this paper with us. The practical and reflexive processes of that artistic play and also this paper lead us to believe that opera has several layers. And it is in those many layers in where the opera's treasure lives. It is neither in the text, nor in the music or dance, but the action that is in this 
amalgam instead. An opera is the action of a theatrical play from the perspective of transgender. As a result, we start understanding what opera is and how the direction of an opera occurs at NUO-Opera Lab. This process as a whole, artistic reflexive, afforded personal turning points, i.e. each member of the play involved in this process had found personal insights, opening to self senses and meanings, while the group's turning points resulted into a more general and shared the ones.

Key words: autoethnography; opera choreography; opera; theatre; dance. 


\section{Sumário}

Dedicatória

Agradecimentos

Resumo:

Abstract

PréTEXTO?

Apresentação

Introdução, ou... O que você precisa saber, ou... Contextualizando 33 50

ROTEIRO

CENA I - FUNERAL

Começa música "Funeral Queen Mary II", Blackout todos fora do palco. .53

Entrada cortejo carregando a rainha. (Chegar até quase de frente do trono) 67

Pose: fazendo alusão a pinturas de Caravaggio. 67

A rainha é carregada até sua "tumba" (deixa: no "Yet" da música). 72

Meninas: começam o movimento de um lado para o outro. 75 
No último "deliver us not" levantar e ir para trás (canto esquerdo do palco).

Cena II - CANÇÃO DA MANHÃ

O Rei canta - solo do Pedro. Durante a canção, todos parados.

Cena III - LAMENTO .78

Rainha sai de seu "casulo" e vai deslocando por trás do tecido.

Seu lamento chega até as costas do trono do rei. .80

MENINAS: durante o lamento, movimentos pequenos $(6,12$, 9 , 3) na bolota. 86

MENINOS: parados em frente ao tecido branco. .88 ANIVERSÁRIO. 90

MÚSICA “COME, COME” (TUDO MODIFICADO) 90

Parte 1: dueto Angélica e Pedro. .93

Meninas do lado esquerdo: círculo. .96 Meninos do lado direito: andam em fila para o outro lado...97 Ao final se colocam de frente para rei e rainha. 99 Parte 2: quando começa a cantar "come" pisar à frente. No segundo "come" (com sua dupla) como se 
reverenciando a rainha na ordem estabelecida, vai para trás da fila.

Parte 3: Trocas do $1^{\circ}$ grupo (Wesley, Isis e Carol); ao final da sequência deles, todos sobem o braço juntos. 107

Trocas do $2^{\circ}$ grupo, ao final da sequência deles todos sobem o braço juntos. 109

Nos grupos, quando fizerem juntos, descem o braço no penúltimo "triumphant" do rei.

Andam para os lugares (meninas de um lado e meninos do outro).

Parte 4: avançadas em cânon (cada um no seu tempo na ordem) 8 vezes.

Parte 5: Pisadas para frente em duplas (plateia) com 0 cotovelo para o alto e volta para o fim do grupo - uma vez.

Troca de frente com cotovelo alto (duas trocas)..... 114

Ida para o chão.

MÚSICA "SOUND THE TRUMPET"

Levantar devagar e saltar para ir para lugar da próxima sequência.

Meninas vão depois (no segundo "sound"). 116 
MENINAS e MENINOS em bolinho de frente os dois grupos 116

Executar a sequência em cânon (cabeça 2 vezes lenta e 4 vezes rápidas, perna lenta para direita e esquerda 4 vezes rápidas). 116 MÚSICA "STRIKE THE VIOL"

Parte 1: MENINAS ENCOSTADAS NA PAREDE - movimento de balanço de um lado para o outro, bem lento - Renata e Carol avançam.

Meninos: célula coreográfica nova (macarena) 118

Parte 2: SÓ MENINAS - Célula coreográfica que vai para o chão. Após repetir a célula, reverenciar a rainha e se colocar no fundo.

Parte 3: Angélica e Pedro fazem dueto coreográfico. 119

Parte 4: Meninos fazem com Pedro. Meninas fazem duas vezes com Angélica (obs.: tirou o braço e perna)..... 120

MÚSICA “THE DAY”. 120

MÚSICA "BID THE VIRTUOS" 136

MÚSICA “THESE ARE THE SACRED” 141

Todos permanecem abaixados 141

MÚSICA “SEE NATURE” MUDANÇA. 
Parte 1: Enquanto cantam, Andreza e Luiz, dançam a coreografia. Coro permanece atrás deles, parados.. 143 $\mathrm{Na}$ última parte da música os dois fazem um dueto juntos. 144

Parte 2: Quando entra o coro, os dois grupos fazem as células com eles. 145

No último pedaço da música, Pedro sai e meninos o seguem e meninas deslocam rapidamente para o outro lado do placo, por trás do trono. 145

MÚSICA "SINFONIA" INSTRUMENTAL

147

PARTE 1: Meninos vão lentamente pelo chão, receber "benção" da rainha.

PARTE 2: Meninas e meninos vão receber benção, intercalando. 150

PARTE 3: em grupo se deslocam no 12 e no 6. 151

Cena VI - SOLO DA RAINHA, CANÇÃO DA NOITE. ............. 152

Cena V - EPIDEMIA DE VARÍOLA. MUDANÇA ............. 152

Começa a chacone - dança da corte - desconstruindo. .. 154

Sete partes 154

Parte I - 24 compassos 155 
Duetos: André e Renata, Luís e Andrezza, Wesley e Isis - o último sente sintomas da doença. 155

Parte II - 30 compassos 156

Eles vão para o lado... Retorna André e Renata e também sentem sintomas; saem. Voltam Luís e Andrezza e sentem sintomas... Os 3 casais e sentem sintomas. 156

Parte III - 16 compassos

Divide em dois grupos mistos, um de cada lado dançam de frente ... Solo grupo I, solo grupo II "contact improvisation"

Parte IV (cellos) - 24 compassos 158

Todos começam a sentir os sintomas, um de cada da dupla. 158

Parte V - 24 compassos 160

Um do grupo da esquerda desfalece, eles o seguram e "tratam dele"; o mesmo acontece com o grupo II. 160

Parte VI - 21 compassos. 161

Cada grupo se divide em dois para "tratar", eles começam a melhorar. 161

Parte VII - 16 compassos 165

Todos se recompões numa apoteose da corte. 165 
Eles percebem que a rainha está morta... Terminam todos em torno dela. 169

Fim de chacone - todos olhando para a rainha. ..............172

Entra o Rei - coro se coloca na frente dele, tentando impedilo. 173

Enfim, ele vê a rainha morta, inspira forte e se ajoelha, e começa a cantar "hush". 174

$\mathrm{Na}$ entrada do coro ele se prostra diante dela de costas para o público. Nunca senta ao trono. 174

O coro forma um agrupamento em torno do trono e faz movimentos de lamento enquanto canta. 176

Ao tocar os tambores, o Rei tira o manto que cobre a rainha. 178

A música do funeral começa... Somente na repetição forte a rainha é erguida. O cortejo começa e todos saem. .. 180 181

Anexo 1 - Fotografias sem edição, Luciano Osório. .................. 188

Anexo 2 - Entrevistados............................................. 211

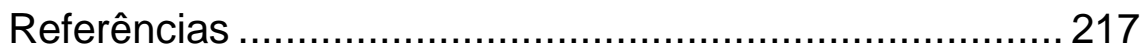




\section{Lista de Imagens}

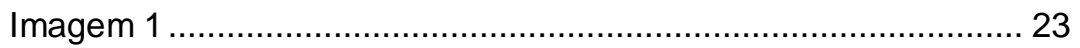

Imagem 2 - Recorte facebook, grupo fechado ............................... 50

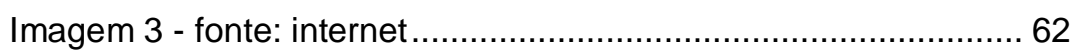

Imagem 4 - Recorte facebook, grupo fechado ……………….......... 64

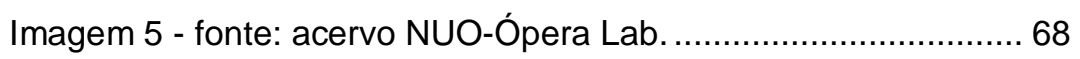

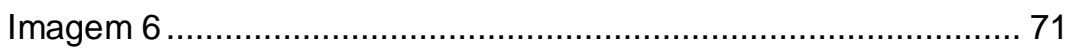

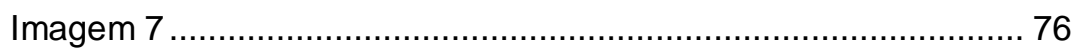

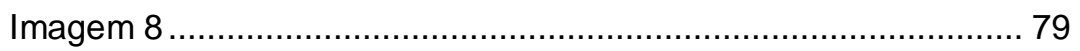

Imagem 9 - Recorte facebook, grupo fechado ............................ 91

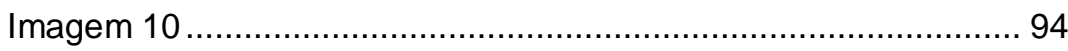

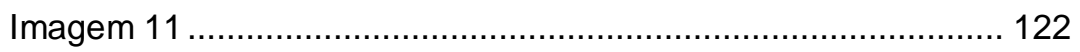

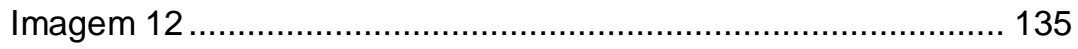

Imagem 13 - Recorte facebook, grupo fechado ......................... 147

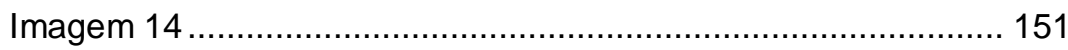

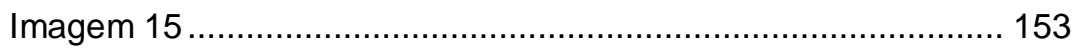

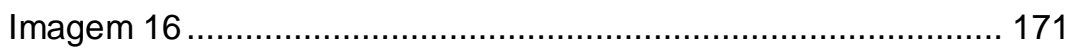

Imagem 17 - Programa distribuído nas apresentações ................ 175

Imagem 18 - Recorte facebook, grupo fechado .......................... 176

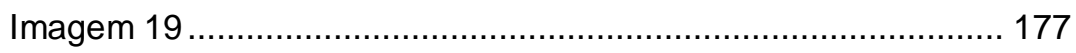

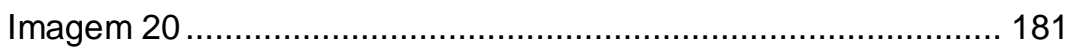

Imagem 21 - Recorte facebook, grupo fechado .......................... 187

Imagem 22 - Foto by Luciano Osório ........................................ 189 


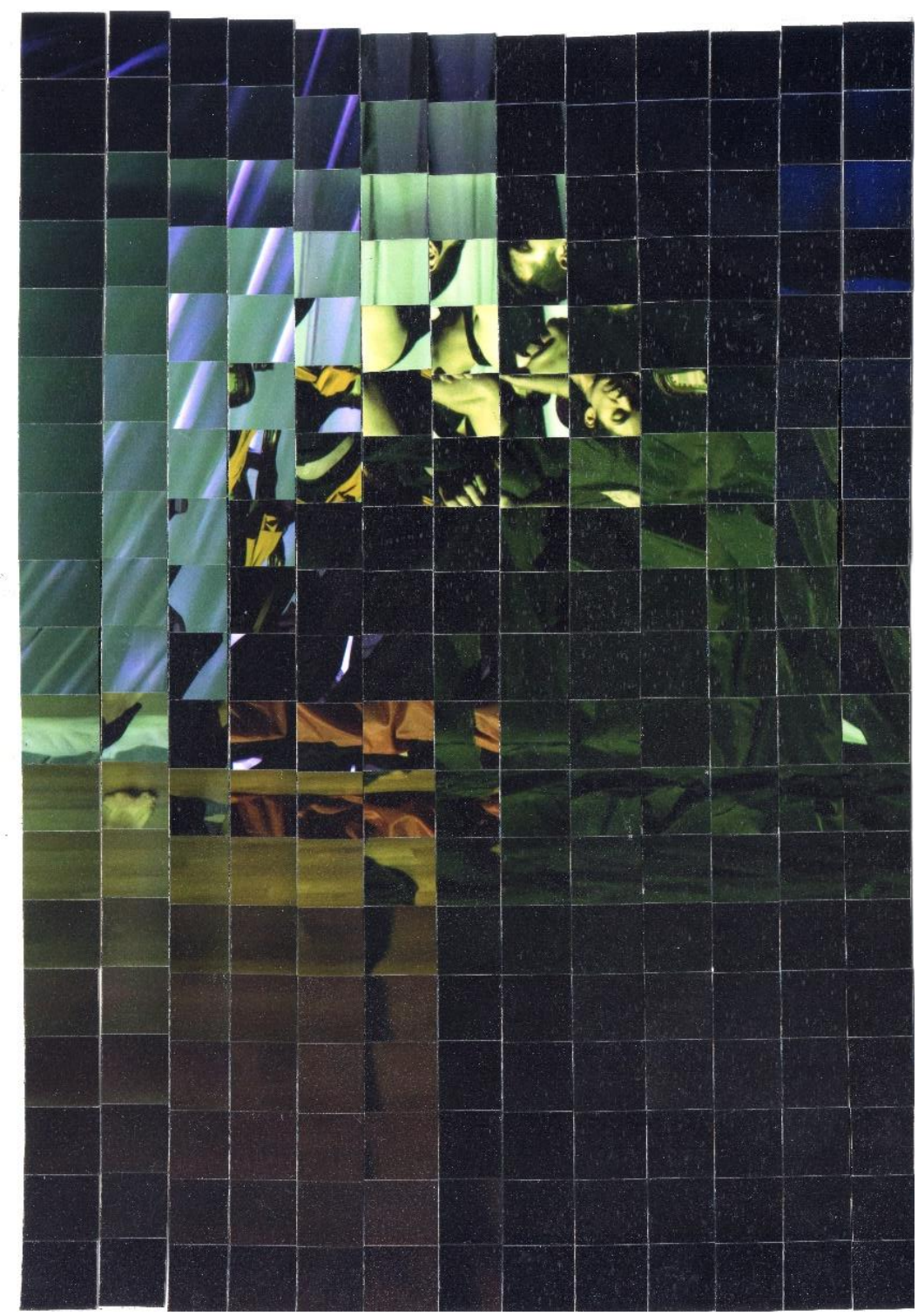

Imagem 1

"A arte não reproduz o visível, ela torna visível. " (Paul Klee) 


\section{PréTEXTO?}

[...] "Estou em modo campo" [...]

[...] "Me deixar levar" [...]

Inicio o texto com uma imagem, uma fotografia (imagem escrita) de propósito. A fotografia aqui é estopim para problematizar e não para exemplificar. Cada imagem fala por si não precisa de explicação. Em uma entrevista com Robert Tanitch no Mature Times publicada em 16 de abril de 2015, Pina Bausch (1940 - 2009) disse ao entrevistador que, se ela explicasse o significado da peça que ele assistiu, ele estaria entendendo a ela, e não a peça. Assim, acontece aqui nesta imagem. Caso eu explique a fotografia, ela perde a potência que tem por si de forma autônoma, e fica reduzida ao que eu acredito que ela é. Portanto, busco contextualizar as imagens usadas/construídas, mas, nunca explica-las.

Após fazer esta imagem, que foi clicada originalmente por Luciano Osorio ${ }^{1}$, fica claro para mim como foi este trabalho do ponto de vista do método como forma de pensamento/ação.

${ }^{1}$ Luciano Osorio é fotógrafo formado pela Full Frame em São Paulo, já trabalhou com Tony Genérico, renomado fotógrafo comercial, e atualmente está à frente de um estúdio fotográfico especializado em 
Olhe a imagem.

Olhe para ela novamente, gaste um tempo com isso...

Percorra seus olhos livremente pela imagem.

Perceba as linhas criadas pelos recortes e as linhas de movimento que a fotografia tem. Seu ritmo, sua luz, seu movimento... e o que mais você conseguir encontrar.

À primeira vista ela não é reconhecível. Sim, porque eu a recortei tantas vezes que ela se tornou outra coisa. Assim, é esse trabalho. Espero que você percorra seus olhos por ele e busque novas perspectivas para encontrar coisas familiares ou não, e enquanto lê, dê-lhe seus sentidos e significados próprios.

fotografia de produtos em São José dos Campos. Acompanha e fotografa o NUO-Ópera Lab. desde 2013. 


\section{Apresentação}

No ano de 2015 eu fui convidado para coreografar uma adaptação de duas cantatas do compositor Henry Purcell (1659 - 1695) que foram adaptadas com uma dramaturgia própria para o NUO-Ópera Laboratório². A montagem denominada "Aniversário e Morte da Rainha Queen Mary II" no NUO-Ópera Lab. foi resultado das pesquisas e estudos que eu ainda faço, mas que foram iniciados naquele momento e foram exaustivamente registrados.

A autoetnografia permite uma abertura para uma sincera e profunda reflexão sobre nós mesmos, nossas relações com os outros, e como nós queremos viver as relações entre saber e sentir. Não é apenas uma maneira de saber sobre o mundo, mas é uma maneira de estar no mundo que exige viver conscientemente, emocionalmente e reflexivamente. Ele requer que observemos nos observando. Além disso podermos interrogar o que pensar/acreditar (JONES, ADAMS e ELLIS 2013).

2 O NUO-Ópera Laboratório é uma companhia de ópera criada pelo Maestro, Diretor e Encenador Paulo Maron em 2003, que desde então vem produzindo periodicamente duas óperas por ano. Composta por jovens estudantes do canto lírico e artistas que buscam novas experiências artísticas. 
Escrevendo sobre mim eu falo a partir do corpo, é uma escolha sintonizada no visceral e somático, meu corpo e minha mente trabalham como uma orquestra, como o lugar onde a história é gerada integralmente, somaticamente, para se manifestar externamente, semanticamente; eu sou meu corpo falando (PELIAS, 2013, p.388).

É desse processo de sensações que esse trabalho trata.

A etnografia é ora disciplina, ora estratégia da antropologia. $O$ que é a autoetnografia? Quando o self pode vir para a descrição. Mas, tem algo que vai atém que é construido a partir da escola de sociologia de Chicago, que é quando a narrativa da minha experiéncia é tão precisa, e eu descrevo de modo tão preciso com os cadernos de campo, com a experiencia de vida, contando quem eu sou e como é que eu ví aquito. Eu narro a experiencia em primeira pessoa, leio aquito que eu narreí e isso já e método. Por que? Primeiro eu narro. Segundo euleio, e quando leio, leio em terceira pessoa porque estou lendo aquela pessoa que escrevew. $E$ quando leio exaustivamente aquela pessoalescritura eu comeco a perceber que aquito que é meu e que en percebi tem conexão com o social mais amplo. Então a autoetnografía é o exercicio que eu, como sujeito social e cultural de um tempo; 
carrego em mim, coisas que não são minhas e que eu não tenho consciência. Ew passo a ter consciência na medida em que eu descrevo - tarefa da etnografia - mas, eu otho - auto - nessa terceira pessoa que euposso ser de mim mesmo e, ao ler percebo que tem uma dimensão em mim que não é minha, que é: cultural, social e mais um monte de coisas. (Maritia Velardi, 2017, arguição qualificação)

Assim pensando nesse exercício de ir e vir no texto, de distanciar e aproximar, após algumas tentativas, cheguei em um lugar mais próximo de como eu penso/método e, mais do que isso, de como aproximar você que está lendo e/ou convidar para entrar na minha ótica, no meu ponto de vista sobre esses fatos sociais, nesta música, nesta coreografia, neste processo, nesta relação, nesta autoetnografia, nesta ópera coreográfica.

Nessa navegação em busca do percurso para tornar consciente as escolhas que fiz para este trabalho, o norte não é a minha referência. Os autores científicos e os autores do meu cotidiano, ou seja, do meu campo, são como faróis para a minha navegação segura, em que o processo é valioso. Esses faróis me guiam para que eu não feche um círculo no meu próprio eu, mas abra um espiral de problematizações. 
A partir do roteiro que o diretor criou em conjunto com o grupo (integrantes do NUO-Ópera Lab.), criamos um outro roteiro que funcionasse como uma coreografia escrita ou como uma partitura que usamos para aprender as músicas. Como tal, ela sofreu inúmeras alterações. Assim, eu resgatei esse documento e o utilizo agora para contar como foi a montagem dessa obra. Ao mesmo tempo que resgato minhas experiências, memorias afetivas e coisas que de alguma maneira me marcaram, pretendo contar uma história, refletindo sobre ela. Um relato refletido, não apenas simplesmente narrado linearmente, até porque, você perceberá idas e vindas na linha do tempo.

Portanto, usei outra forma que não a clássica para escrever este trabalho, busquei uma escrita mais performática ${ }^{3}$. Assim,

${ }^{3}$ Norman K. Denzin, explica que é por meio da interpretação do pesquisador, que o mundo da experiência se torna accessível, ou seja, é essa tentativa de trazer a sensação para quem lê, ouve, assiste, sente. Colocar as pessoas no lugar de quem passa e/ou vive tal sensação, trocando os papeis. A importância de Performar dados utilizando as diversas possibilidades da escrita e até das artes e do fazer artístico para a pesquisa qualitativa. "Experiências atuadas são os lugares onde a emoção, memória, desejo e compreensão vêm juntos, e são sentidas. Eu estou procurando interpretações performáticas... elas são poéticas, dramáticas e imaginativas. É um processo contínuo de trazer para a superfície; cavando, olhando, sentindo, movendo, através de por exemplo: topografia, cartografia e memórias. Re-localizar; novas memórias (tradução nossa). DENZIN, Norman K. Re-leyendo performance, praxis y política. Investigación Cualitativa, v. 1, n. 1, p. 57-78, 2016. 
mantive a estrutura do roteiro original feito em conjunto com o grupo, com a fonte Arial, e fui recortando e acrescentando as falas dos autores/artistas/atores/cantores/ diretores/dançarinos/participantes/músicos(...) do meu campo, e expresso aqui meu maior desejo que é trazer à tona o que esse campo tem a dizer. E afirmo: Eu não sou o porta voz deles, mas sim a pessoa que os ouve. E, portanto, busca um diálogo. Por isso, trago as citações em recuo, com a fonte "Lucida Handwrinting" em tamanho 12, para que eu converse com eles e não fale por eles. O tamanho da impressão, em A5, foi escolhido para que você que está lendo possa tocar o trabalho com um todo, o tempo inteiro. Todas as imagens, entrevistas, falas, assim como todo material contido neste trabalho recebeu o consentimento das pessoas entrevistadas e/ou fotografadas para a divulgação neste trabalho. 


\section{Introdução, ou...}

\section{O que você precisa saber, ou... \\ Contextualizando...}

Como pesquisador qualitativo ${ }^{4}$, debruço-me a olhar e perceber as questões do meu cotidiano, ora distanciando-me dele, olhando os cadernos de campo que me acompanham/acompanharam nas experiências artísticas que faço, ora me aproximando e refletindo sobre questões particulares. Além disso, estou interessado nos percursos e processos que permeiam a vida acadêmica/artística. $O$ que estou tentando dizer com isso é que, a maneira como as pesquisas acadêmicas/artísticas são formuladas e como são respondidas se mostram atraentes para mim, e me instigam a querer compreender mais o mundo/campo/ambiente/palco que habito. Sendo assim, esse estudo está mais direcionado a descrever/desvendar o método (como forma de pensamento) e/ou o caminho que percorri (ação). Logo, este

${ }^{4}$ Assumo esse lugar de pesquisador devido a classificação de pesquisa que me debruço a investigar como Norman K. Denzin e outros muitos pesquisadores dessa natureza apoiam-me a fazer. Assumir isso é uma posição política e pedagógica já que eu não estou fazendo aqui uma pesquisa do tipo quantitativa ou epidemiológica por exemplo. 
trabalho é, antes de tudo, uma posição política e pedagógica que você desvendará ao longo de sua leitura.

Vou trazer a fala da Profa. Dra. Marília Velardi ${ }^{5}$ do dia 31 de agosto de 2016 no evento/mostra LAPETT (IN) PROCESSOS que reuniu trabalhos de alunos de mestrado e doutorado realizados junto ao Laboratório de Pesquisa e Estudos em Tanz Theatralidades (ECA-USP). Fundado em 2011, o LAPETT é dirigido por Sayonara Pereira. Neste dia, houve também o lançamento do livro: "Trajetórias em Construção: Escritos Cênicos dos Pesquisadores do LAPETT" (Leticia Olivares e Sayonara Pereira, orgs. Ed. Prismas, Curitiba). Ao discursar sobre a suas contribuições e inquietações a professora explica:

[...] é um livro que é resultado de encontros e reflexóes académicas ou de reflexóes de vida. Esse livro traz isso. Eutive a honra de fechar o texto com algumas elucubraçós que en fiz. Ele tem histórias de vida que se convertem com histórias acadêmicas que retroatimentam as histórias de vida. É um outro processo que depende de uma coisa, que para mim é

${ }^{5}$ Por orientação da banca de defesa, todas as biografias e/ou currículos das pessoas citadas estão disponíveis no item Anexos 2. 
uma das coisas mais importantes da vida, que saio os encontros. Mas, dos encontros verdadeiros, of encontros das quais a gente compartitha as presencas e não só compartitha as ideias" (Maritia Velardi, 2016, fala do Lapett).

É desses encontros de presença que eu pretendo falar. Portanto, essa fala me inspira a fazer aquilo que, como pesquisador qualitativo, acredito e aprendi que tem que ser feito. A Professora segue e me localiza, dizendo que estamos dentro de um programa de pós-graduação em artes da cena na Universidade de São Paulo, e que os programas de pósgraduação são mais cruéis em relação ao que se espera da pós-graduação do que o próprio regimento da pós-graduação da USP. Ela traz para essa apresentação algumas partes do Regimento, que eu disponibilizo na integra a seguir:

\section{Capítulo I - Dos Objetivos}

Artigo 1- - Pós-Graduação stricto sensu, voltada para a geração do conhecimento, destina-se à formação de docentes, pesquisadores e profissionais com amplo domínio de seu campo do saber e capacidade de liderança e inovação.

Artigo $\quad 2^{\circ}-\quad A \quad$ Pós-Graduação stricto sensu compreende um conjunto de atividades realizadas no âmbito dos Programas de PósGraduação, acompanhadas por orientador, específicas para cada pós-graduando, as quais incluem e 
privilegiam o ensino e a pesquisa, visando à integração do conhecimento e o desenvolvimento da sociedade.

$\S 1^{\circ}$ - A Pós-Graduação stricto sensu deve ser entendida como um sistema de formação intelectual $e$, ao mesmo tempo, de produção de conhecimento e inovação em cada área do saber (Regimento da PósGraduação da USP).

Não me cabe analisar o regimento neste momento, mas, basta uma leitura atenta para compreender que o que a Professora nos lembra, ou seja, em nenhum momento se pede ou exige fazer ciência, do ponto de vista clássico. Ela segue questionando a mim e as outras pessoas presentes:

Eu fico pensando onde estão as amarras? Que dizem que a gente não pode performar os dados. Que dizem que a gente não pode falar do nosso campo. Que dizem que a gente não pode falar das nossas experiencias. Que dizem que a gente não pode fatar em primeira pessoa.

Eu acho que é muito simples encontrar formas de transgredir àquelas verdades universais que dizem que nós não podemos vatorizar quem nós somos e aquito que fazemos. Uma das formas é estar em grupo, nos fortalecer nesta unidade e produzirmos coisas que digam quem nós somos. Fazendo isso fazemos essas transgressóes se reatizarem. 
A pós-graduação está aberta para nós fazermos da nossa experiéncia de vída e da nossa vida algo que de fato mostre para as pessoas que o conhecimento que nós temos e que queremos compartithare colocar uma outra dimensão nele é passivel de ser feito. A gente consegue fazer sem ter que abaixar a cabeca para aquito que dizem que é certo ou que é cientifico (Maritia Velardi, 2016, fala do Lapett).

Além de me sentir afetado por estas palavras que ainda ecoam em mim, eu ganho confiança para (tentar) cumprir com o meu papel. Falar/escrever dos processos e experiências artísticas do campo que eu vivo/vivi. As transgressões citadas pela professora são compreendidas por mim no sentido de conseguir coerência da investigação como um todo, ou seja, trazer para o texto as práticas e mostrar a articulação de como aquilo que foi vivido, criado, performado, e como isso pode se misturar com o texto acadêmico, sem que se diga que um é resultado do outro, mas que se diga:

[...] isso é a producão, isso é o aprofundamento sobre mew campo de conhecimento (Marítia Velardi, 2016, fala do (apett).

Acredito nos processos. E foram os processos que me levaram ao caminho dessa pesquisa e que se fizeram ao 
longo do percurso. Estou mais ligado ao que é sensível em oposição àquilo que é objetivo. Tomo como inspiração Tim Ingold (Antropólogo e Professor na Universidade de Aberdeen na Escócia) que explica como a vida está em fluxo. Ingold (2012) vem desenvolvendo uma abordagem que ele chama de obviação (obviation), com o intuito de trazer ênfase ao fluxo da vida, às continuidades, aos crescimentos, aos desenvolvimentos. Quero falar desses fluxos e das rupturas que ocorrem durante a vida ordinária e a vida na pesquisa. Assim, a história contada importa tanto quanto a maneira "como" esta história será contada.

"I'm not interested in how people move, but in what moves them" (Pina Bausch).

Assim, para Pina Bausch, não é a qualidade de movimento (how) das pessoas que importa, mas o que vem antes/durante esse movimento (what) acontecer. Ou seja, os caminhos/processos percorridos até esse movimento e durante esse movimento. Mais uma vez as transgressões propostas aqui serão justificadas o tempo todo e elas acontecem não porque eu quero, mas faço uso daquilo que seja melhor, mais expressivo e/ou aquilo que o próprio 
trabalho pede para que haja coerência entre conteúdo e forma ${ }^{6}$. Sobre essa coerência Velardi (2018) discorre:

Essas reflexões aparecem num tempo em que persiste e segue fundamental o questionamento sobre os lugares de fala, especialmente sobre quando alguém está falando por outro alguém. É pertinente também nos colocarmos diante da crítica sobre a ausência das histórias humanas contadas nas pesquisas como experiências e não como fragmentos. Um tempo em que precisamos resgatar a importância das contações de histórias a partir do ponto de vista da pessoa pesquisadora, que também é sujeita às experiências que narra. E que pensa, reflete, critica, revê, rememora, desdobra o que viveu enquanto conta para si as suas histórias. É, também, uma posição colocada para valorizar as ausências e os silêncios daquelas pessoas que não teriam direito à voz caso não falassem por si (VELARDI, 2018, p.51).

Entendendo essa sensibilidade como a qualidade do que pode surgir ela continua:

${ }^{6} \mathrm{O}$ texto não está nos moldes tradicionais pois ele nasce da interação com os integrantes do NUO-Ópera Lab. durante o processo de montagem da obra que será descrita. Desta maneira, o texto é reflexo das relações do cotidiano, logo, busco uma escrita mais coloquial com o intuito de ser performático. Pois, busco escrever como quem conversa com os autores e com a experiência. Considero aqui autores todos aqueles que cito, uma vez, que cada um tem a sua autoria no cotidiano e sem suas falas esse texto não seria este, seria outro. Um exemplo disso é o autor Johnny Saldaña em seu artigo "Blue-Collar Qualitative Research" publicado em 2014. Seu texto é cheio de gírias e falas coloquiais, pois é escrito do ponto de vista e preservando o lugar de fala da classe operária. 
Essas reflexões também nos colocam frente à perspectiva de como os diários de campo, os cadernos de artistas, as anotações dos processos e intuições que Ihes atravessam, assim como as imagens fora de foco, os vídeos com ruídos, as conversas fora de hora são, algumas vezes, mais interessantes do que os relatórios produzidos. $E$ isso marca uma posição contrária à crença de que os discursos sensíveis e impressões afetivas levam à perda da objetividade ou seriedade da pesquisa (VELARDI, 2018, p.51).

Ancorado na perspectiva da investigação radicalmente qualitativa, que aponta que, na atualidade as investigações dessa natureza devem ser essencialmente colaborativas e que os colaboradores possam sair desse processo com ganhos em termos de desenvolvimento pessoal, busquei os participantes (atores/cantores, diretor, equipe, coreógrafos, artistas, plateia) para me ajudem e/ou auxiliem a (re)conhecer os processos. Apoio-me também nas afirmações de Eduard Dort (1929 - 1994) era francês, crítico e teórico do teatro e escreve sobre a crença do diretor e pedagogo teatral, Stanislavski (1863 - 1938), em relação à importância dos processos dialógicos compartilhados sobre o que é ser artista.

"Convinha, portanto, acrescentar à prática uma reflexão sobre esta mesma prática. E também comunicar os resultados desta reflexão aos demais. Pois se é impossível suscitar o aparecimento de criadores, é possível e mesmo indispensável indicar aos homens de teatro, sobretudo aos atores, os caminhos através dos quais poderão atingir este 
"estado-criador", fora do qual não existe a arte do teatro" (DORT, 1977, p.102).

Investigar o que o campo solicita é tarefa do pesquisador dessa natureza, radicalmente qualitativo ${ }^{7}$, e isso só é possível quando existe uma imersão profunda e um comprometimento com esse campo, pois é desse lugar, com base nessas experiências, que as questões são formuladas.

Westey, comecou já estragado. Em geral no discurso da Educacão Fisica, nas Ciências da Atividades Fisica que foi $\sigma$ curso que ele entrow, o discurso das ciências mais duras - não que a EF (Educacão Fisica) seja, porque EF éprática pedagógica-mas bebendo ati na fonte das ciências biomédicas ou das ciências da

7 Repito esse termo algumas vezes propositalmente durante o texto com consciência e como estratégia já que as pesquisas "radicalmente qualitativas" é (são) uma estratégia de pesquisa relativamente nova e mais do que dizer o que é, minha pretensão é fazê-la, uma vez que esta estratégia rompe com os padrões de pesquisa tradicional, portanto informar o que estou fazendo é importante. O texto: "Questionamentos e propostas sobre corpos de emergência: reflexões sobre investigação artística radicalmente qualitativa" de Velardi (2018) é esclarecedor. Ela fala: "A chamada terceira geração das pesquisas qualitativas norteamericanas assume que, mais importante do que a disciplina a qual a pesquisadora está vinculada, é essencial que quem faz pesquisa seja uma pessoa comprometida não só com uma área, mas com o campo da investigação, suas histórias e contextos. E nessa perspectiva, ser do campo, estar mergulhada nele e saber quem se é como pessoa e pesquisadora desse/nesse campo é uma exigência, uma necessidade, uma responsabilidade radical". 
saude, o método em geral é o método cientifico tradicional. E ai quando a pessoa vai para o tipo de método que prescinde da experiéncia pessoal, ela tem que desconstruir uma série de lógicas do método cientifico, que é um pouco do que a gente faz na disciplina, para poder dar conta do outro método, que é esse quatitativo radical. A gente é formada, ao longo da nossa escolarização toda, para pensar a vida pelo método cientifico. A escola é toda dividida com base na ciência, que diz como a gente aprende as coisas e como a gente aprende melhor.

Invariavelmente essa pessoa tem que passar por um processo de desintoxicacaio desse método para depois trabalhar como método qualitativo. $O$ Wesley não teve essa intoxicacaio. Então eu acho que tem um mérito a tua formacão no ensino médio ter sido atropelada como você sempre cita, por estar no periodo noturno, por naio ter tido algumas disciplinas, assim ela (a tua formacão) teve um valor a ponto de te intoxicar menos, e ai você já começou com essa perspectiva do qualitativo com mais simplicidade, o que te levow a othar para determinadas questöes postas pelos seus colegas de sata, por exemplo, até aqui na 
disciptina que você fez, que é: - não estow entendendo porque eles não estão entendendo porque não pode fazer assim. porque eles estavam nesse processo de tomada de contato com alguma coisa que parecia menos cientifico e você não tinha feito esse voto de castidade, com a ciência (Maritia Velardi, 2017, arguição quatificacão).

Tomando consciência desse pensamento, busco uma escrita que traga à vida os processos pelos quais eu tive a experiência, conversando com os participantes e colegas, olhando para os registros audiovisuais e escritos tanto no caderno de campo, quanto aqueles feitos via redes sociais. Buscando sempre a ideia de trazer à vida e tornar visível assim como Ingold (2012), traz em seu texto "Trazendo as coisas de volta à vida: emaranhados criativos num mundo de matérias". Ele cita o artista Paul Klee (1879 - 1940) que por sua vez já defendia e demonstrava através de seus diários, que mais tarde foram publicados "que os processos de gênese e crescimento que produzem as formas que encontramos no mundo em que habitamos são mais importantes que as próprias formas". Assim "A forma é o fim, a morte, o dar forma é movimento, ação. O dar forma é vida. " (KLEE, 1973, p.269). Como artista ele estava em constante busca de responder aquilo que Ihe inquietava: a arte. Para 
ele, a arte não busca replicar formas acabadas e já estabelecidas, seja enquanto imagens na mente ou objetos no mundo. Ela busca se unir às forças que trazem à tona a forma. "A arte não reproduz o visível; ela torna visível" (KLEE, 1961, p.76 e INGOLD, 2012).

O pesquisador se coloca em um lugar vulnerável e de fácil julgamento dependendo de quem o lê. Os significados não são estanques, completos, imparciais e/ou passiveis de universalização. Assim, como a coreógrafa Pina Bausch fala que a sua obra é aberta e o público faz parte da obra tendo que sentir. Ou seja, ela chama o público para completar com sua imaginação e sensorialidade, suas coreografias, que são conhecidas por conter elementos surrealistas e expressionistas.

Por isso escolhi olhar para o tema partindo do campo das experiências. Para Bondía (2002, p.21), experiência é aquilo que "nos passa, que nos acontece, o que nos toca", é algo que se prova, é aquilo que acontece e nos afeta de algum modo, como uma superfície sensível, "produz alguns afetos, inscreve algumas marcas, deixa alguns vestígios, alguns efeitos". Jorge Larossa Bondía (2002, p.26) propõe "uma reflexão do sujeito sobre si mesmo enquanto sujeito 
passional", a partir da lógica da paixão sobre aquilo que o afeta.

Para formular as questões da pesquisa eu me propus a fazer o seguinte exercício: uma redação espontânea, rica em detalhes, passional, em um primeiro momento descrevendo minhas experiências com o Teatro Musical e/ou Ópera. No segundo momento eu filtrei, busquei um distanciamento, pois como Bondía (2002) explica, a experiência precisa de um distanciamento e um tempo da vivência vivida, para que a experiência apareça. Retirei aquilo que parecia ser descritivo em demasiado e mantive o que caracterizava a experiência. A partir daí, tracei as questões que de alguma maneira, já estavam me movendo, mas que ainda não eram conscientes. Observo, então, que estão aí os problemas da pesquisa. Logo,

[...] a experiência tem uma dimensão de incerteza que não pode ser reduzida. Além disso, posto que não se pode antecipar o resultado, a experiência não é um caminho até um objetivo previsto, até uma meta que se conhece de antemão, mas é uma abertura para o desconhecido, para o que não se pode antecipar nem pré-ver nem pré-dizer (BONDÍA, 2002, p.28).

Após esse salto no escuro, comecei a observar no meu texto pontos de inquietação. Necessitei, então, recorrer à literatura para tentar responder a essas questões e percebi que as 
inquietações pessoais tinham algumas convergências com a literatura. Consegui localizar ao longo da história até a contemporaneidade aquilo que eu estava questionando. Além de proporcionar uma ampliação sobre o panorama desse campo.

Acredito que aquilo que se materializou como experiência para mim, para os artistas envolvidos e como resultado estético pode ser discutido, interpretado e "performado", na busca da ampliação de um campo das artes da cena: a ópera.

"[...] justamente o que faz do trabalho de campo um trabalho tão difícil é que, normalmente, ao simplesmente levar a vida, continua-se levando e lidando com as coisas conforme elas surgem" (INGOLD, 2012, p.05).

Talvez seja esse o grande anúncio para mim nesta pesquisa. Pois, enquanto vivo, enceno, ensaio, pesquiso, entre outras ações do cotidiano, as perguntas surgem, e conforme aparecem, vem junto a necessidade de respondê-las.

Aquelas coisas que parecem absolutamente comuns e normais se tornam questões. E, em campo, eu acho que as investigamos com as pessoas com quem trabalhamos, as quais, frequentemente, também ficam perplexas com elas, e, como todos sabem, 
gerando interessantes discussões conosco (INGOLD, 2012, p.05).

Entro em contato com Ingold, no ECOAR, Grupo de Estudos em Corpo e Arte, dirigido pela Professora Doutora Marília Velardi, que é sediado na Escola de Artes, Ciências e Humanidades (EACH-USP) que atualmente tem como focos: (a) a construção de conhecimento com artistas sobre a Arte; (b) a busca por epistemologias artísticas como suporte para as investigações qualitativas e (c) a criação de estruturas de performances dos dados ou dos conhecimentos produzidos nas investigações. Assim, Ingold ilumina meu caminho percorrido quanto à discussão com as pessoas com as quais eu convivo, mas, em algum momento isso toma proporções nas quais eu desejo me aprofundar com a ajuda dessas pessoas.

Logo, procurei separar as informações das experiências, identificar e separar as coisas que pareciam absolutamente comuns e normais, e transformar em questões com o intuito de buscar um foco para a investigação.

Procurei apontar para os estudos teóricos que dão suporte para as escolhas feitas a priori para a pesquisa, bem como aquelas que descobri no percurso, desenvolvidas a posteriori, ajudando a iluminar o caminho à medida que eu compreendia 
o que já foi dito sobre o tema estudado, uma vez que o caminho foi traçado ao longo do percurso de investigação. Portanto, a revisão bibliográfica me ajuda a (re)conhecer e contextualizar a pesquisa.

As investigações desse gênero se dispõem a coletar uma variedade de materiais que incluem: experiência pessoal, introspecção, história de vida, textos de produções culturais, textos históricos, entrevistas, artefatos, vídeos entre outros. Estes materiais ajudam a descrever momentos e significados rotineiros e problemáticas nas questões dessa investigação. Logo, como sugerido na literatura que ampara os postulados das pesquisas qualitativas, troco a ideia de hipótese por intuição (DENZIN \& LINCOLN 2010). 
A sensação está no corpo Passa pelo corpo, fíca no corpo

Mas, o corpo não é eterno. para onde vai tudo?

Memórias, estão só as memorias. Mas, a memóría está no corpo? Ou a memóría está no cérebro?

Onde fica a memória, no corpo ou no cérebro? Emambos.

Mas, um dia não vaú ter corpo. Vai sobrar alguma coisa? "Hush, no more. Be sitent at all" (Eliane Gama). 
Renata Matsuo carregou um arquivo.

11 de junho de 2015

Oi pessoal,

Andrezza Reis e eu refizemos o roteiro.

Em vermelho as mudanças

em amarelo destacado o que mudamos após vocês terem ido embora

beijos e bons estudos! ATé mais tarde

w

roteiro-ANIVERSÁRIO-E-MORTE-DA-RAINHA-MARY-I1....

Documento

Curtir

Comentar

\section{ROTEIRO}

Imagem 2 - Recorte facebook, grupo fechado

Durante o período dos ensaios nós fazíamos a preparação corporal. Eram processos que nos levavam a sentir o nosso próprio corpo e a desenvolver o corpo do personagem e agora, nesse caso, a coreografia. A preparadora corporal é então responsável por encontrar caminhos para que os artistas encontrem as qualidades de movimento que o diretor espera ver em cena. 
E aú? Me conta? $\mathcal{O}$ que sobrow? $\mathcal{O}$ que você sentur? $O$ que fícou? Onde foi fácíte prazeroso e onde foi mais complicado e menos confortável? $O$ que você aprendew? (Marítía Velardi - diárío de campo)

Perguntas como essas são sempre feitas após as práticas que fazemos que são inspiradas nas lições de Feldenkrais. Essas reflexões também fazem parte das minhas diretrizes para escrita deste trabalho, perguntando-me constantemente e buscando responder a essas inquietações. Sentir o/no corpo... as memórias foram evocadas o tempo todo, assim como Ecléa Bosi (2012), em seu livro "Memória e Sociedade", nos lembra "fica o que significa". 


\section{CENA I - FUNERAL}

Nas coxias resgatamos o trabalho de respiração que fizemos durante a preparação corporal.

Inspira, solta o ar.. inspira novamente segura, inspira mais um pouco, solta $\sigma$ ar.. sintam os pés apoiados no chão. Inspira, inspira mais umpouquinho, solta o ar (Marítia Velardi - diário de campo).

Algumas pessoas da plateia relataram ouvir esse momento, a respiração dos artistas, e diziam sentir o prenuncio da emoção que estava por vir. Comentaram também o encantamento por estarem em um espaço menor, onde a plateia fica mais próxima dos atores, e que assim era possível ouvir até a nossa respiração em cena e fora da cena, nas coxias.

A entrada da rainha morta. Sütêncio, escurídaio.. a tensão da respiraça pesarosa! $O$ peso do corpo! $O$ peso da perda! $\mathcal{O}$ peso do sofrimento! Ela se for (Eliane Gama). 


\section{Começa música "Funeral Queen Mary II",}

\section{Blackout todos fora do palco.}

Foi assim o início, como um blackout, sem ninguém em cena, sem nenhuma certeza de como seria o resultado do novo trabalho do NUO-Ópera Lab., mas, confiante porque sabia que sendo fiel aos processos além de um resultado ótimo, teria experiências e novos aprendizados.

Da mesma maneira que eu não tinha hipóteses para esta ópera coreográfica eu também não tinha hipóteses para este trabalho. A investigação que me debruço a fazer é de natureza radicalmente qualitativa (VELARDI, 2018), logo, não trabalho com a ideia de hipótese, pois isso resultaria em lógicas e racionalidades que não são utilizadas nem na formulação do problema nem no método de investigação. A hipótese é usada quando o método (compreendido como forma de pensamento) é o hipotético dedutivo, forma de organização racional adequada à resolução de problemas nos quais os conhecimentos profundos dos resultados empíricos de outras investigações dão suporte para a formulação de duas ou três respostas hipotéticas para situações ou problemas cujas respostas ainda não foram testadas empiricamente. Logo, o pesquisador cria situações experimentais, por exemplo, e testa as diversas hipóteses, 
inclusive as que permitiriam a identificação negativa das premissas ou postulados concebidos como verdadeiros a priori.

A pesquisa que é pertinente fazer no caso do problema formulado é a pesquisa qualitativa considerada mais radical, inspirada na Escola de Chicago de antropologia. O radicalismo refere-se à ideia fortalecida nos anos de 1980 de que haveria uma crise de representação nas pesquisas de campo. Isso porque "o lugar da fala", ou seja, a formulação de problemas de investigação e a busca de respostas era geralmente investigada por pesquisadores que iam ao campo investigar. A crise da reapresentação questiona: quem representa a quem? Em resposta a isso, o pesquisador pode/deve ser alguém que vive a vida do campo que se propõe investigar. Os problemas que precisam ser investigados são formulados no percurso, num processo contínuo de reflexão e problematização do pesquisador sobre si, o seu campo e as experiências. Nesse caso, indução e dedução combinam-se com outro método: a intuição. A hipotetização, portanto, como forma de ordenação da 
racionalidade experimental não tem lugar nesta equação (VELARDI, 2017, comunicação pessoal' ${ }^{8}$ )

Queen Mary foi uma montagem que me marcou muito por diversos motivos: primeiro, o fato de ter sido o primeiro espetáculo de que participei que foi especialmente concebido para o grupo. Ou seja, o espetáculo se moldow ao grupo, e não o contrárío, como geralmente acontece quando se faz o repertório tradicional. Isso já dá uma sensacão gostosa de grupo, uma atmosfera criativa deticiosa (Pedro Ometto).

O artista, Pedro fala sobre a atmosfera criativa e como o diretor nos inclui o tempo inteiro como criadores do que estamos fazendo; para mim isso é importante e já me aparece um turning point pois o papel do diretor/pedagogo se revela, o que vai de encontro com a ideia dos diretores que trazem as cenas prontas e apenas as marcam com os atores. Não consigo deixar de mencionar o "estado criador" que Eduard

${ }^{8}$ Comunicação pessoal durante a reunião do grupo de Estudos em Corpo e Arte (ECOAR), realizado na Escola de Artes Ciências e Humanidades (EACH), no dia 10 de abril de 2017 durante as discussões sobre as inspirações da antropologia para a prática da pesquisa qualitativa, amparado no texto "A escola de Chicago" (BECKER, Howard1996) 
Dort (1929 - 1994) nos traz, conforme já citei antes aqui, o que me faz querer trazer isso também para a forma de escrever o trabalho. Mais tarde nós (todos) descobriríamos que seria uma ópera coreográfica, ou seja, esse nome/gênero foi descoberto durante o processo e não foi determinante para as escolhas que fizemos.

Quando opauto me fez o convite para ajudar a montar de uma ópera coreografada do inicio ao fim, sem a construcaio de cenas mais sim de coreografias, não que a coreografía não seja uma cena, mas que ela fosse inteiramente dancada, eu me assustei no inicio confesso. A primeira coisa que en quis fazer foi recusar porque en não me sentia preparada para isso. Mas, com a confianca dele e também por estar coreografando junto com Westey e estar com a Marítia, na preparaçá corporal, atém de confiar na capacidade e integra dosintegrantes do NUO-ópera Lab. que são artistas e, portanto, estão abertos para novos desafios e experiencias (Renata Matsuo).

O convite para tal empreitada veio do Diretor Paulo Maron, com o desafio para Renata Matsuo e eu coreografarmos, do 
primeiro ao último acorde musical, com todos os artistas em cena o tempo todo.

Este espetáculo, de canto e dança, foi concebido especialmente para o NUO-Ópera Lab. e é, basicamente, a junção de duas cantatas do compositor do Barroco inglês Henry Purcell: "Music for the funeral of Queen Mary II" e "Ode for Queen Mary's Birthday". Além disso, foram agregadas outras canções e obras instrumentais de Purcell (Texto publicado nas redes sociais, facebook).

Eu já tinha tido a experiência de coreografar algumas cenas ou músicas de outras produções do NUO-Ópera Lab., sempre em parceria com o diretor na qual me dava suporte, direções, confiança e liberdade para trabalhar, o que eu julgo fundamental para um resultado coeso com a obra. Mas uma ópera inteira? Do começo ao fim? Com todos em cena? Como seria?

Quando você fala que é a coreografía que acontece do inicio ao fim, como ela se dá. Eu fiquei pensando nessas coisas. Ela se dá corporalmente, como uma dramaturgia corporal que acontece presente no corpo e não como justa posicão. sabe como uma coisa que vai se justa pondo ou como uma colcha de retalhos que vai colando (Vanessa Macedo, 2017, arguicão quatificacão). 
Vermos nas linhas que se seguem como se deu esse processo. Resgato aqui um pouco da minha história com o intuito de localizar você. A ideia é tratar da ópera coreográfica como gênero a partir do olhar de alguém que acredita que faz esse gênero, que está inquieto dentro e fora dos palcos.

A minha relação com a dança, com o teatro e com a ópera está diretamente ligada às minhas experiências profissionais com essas práticas. Em 2011 participei do musical "Evita" direção de Jorge Takla (Teatro Alpha); também em 2011 ópera "Os Gondoleiros" com NUO-Ópera Lab., a primeira ópera no Teatro Municipal de São Paulo foi em 2012 (como bailarino) com o Título de "Magdalena" - direção de JeanPhilippe Delavault; com o NUO-Ópera Lab. no mesmo ano, 2012, eu atuei em "Fary Queen" - direção de Paulo Maron. Aqui citei meus primeiros contatos com essas possibilidades artísticas. Desde então comecei a formular questões ligadas aos processos desses espetáculos, já que trabalhei com diferentes diretores e produções, cada um com suas particularidades. Contudo, comecei a identificar algumas inquietações que se repetiam e culminaram na produção de "Aniversário e Morte de Queen Mary II".

Essas inquietações/questões/problematizações deixam o campo das ideias e das discussões com colegas atores- 
cantores-dançarinos próximos e são levadas à reflexão na academia, durante a graduação em Educação Física e Saúde (2010 - 2015), no desafio de pesquisar "A ópera que se dança: um estudo sobre Orfeu e Eurídice de Gluck coreografado por Pina Bausch" (Iniciação Científica, 2014) e "Arts Based Research e o estudo do movimento expressivo" (Trabalho de Conclusão do Curso, 2015).

A experiência que tenho como artista somada a minha formação acadêmica levaram-me a formular questões ligadas aos processos dos espetáculos com os quais tive a oportunidade de experiênciar ao logo da minha carreira. Nesse período, entre 2011 e 2013, participei de algumas montagens de ópera e teatro musical com diferentes diretores e em diferentes teatros.

Mais do que um percurso investigativo, acredito que dividirconstruir-partilhar das experiências propostas pela investigação descrita aqui, contribuíram para o meu próprio processo reflexivo, bem como a tomada de consciência dos caminhos escolhidos durante o processo como um todo, de modo crítico reflexivo, desde o método escolhido, até a produção artística construída.

A coreografia não é inerente a ópera, portanto, a ideia de ópera coreográfica vem ao encontro de fazer uma ópera 
coreografada do começo ao fim. Coreografar a ópera completamente. O simples fato de ter uma ou mais coreografias inseridas na ópera não quer dizer que ela é coreográfica. Na banca de qualificação a Dra. Vanessa Macedo me fez refletir sobre o cuidado de descrever ao invés de prescrever.

A pessoa comeca a prescrever tudo que tem que ter para ser determinada coisa. Desta maneira se perde a oportunidade de ir vendo o que é tem ati para compor e se comeca a dizer assim "não tem isso então não é dança contemporânea", "ah não tem isso, naio é vídeo danca" vaú-se vendo oque não tem para tentar dizer o que não pode ser. Então, essa questão de descrevere prescrever achei que era um aspecto interessante (Vanessa Macedo, 2017, arguiç̃o qualificação).

Por isso, tomo esse cuidado e busco ser mais descritivo e menos prescritivo. Já que definir esse gênero não seja tarefa para um parágrafo.

Para realizar essa tarefa fiz um roteiro que se estruturou desta forma:

Introdução instrumental - "Funeral of Queen Mary": (Cortejo fúnebre) / O coro canta a primeira parte da cantata "The Funeral of Queen Mary II", de Purcell. 
Em seguida são incluídas a canção "The Morning Song" de Purcell, cantada pelo personagem do Rei William D'Orange e o "Lamento" de Dido e Aeneas, cantada pelo espírito da Rainha Mary. Após um blecaute, vê-se a Rainha Mary seis meses antes; começa, então, a cantata "Birthday Ode for Queen Mary II". A partir daí todas as partes são dançadas e cantadas pelos solistas e coro.

Após o final da cantata "Ode ao aniversário de Mary II" inclui-se a canção "The evening song", cantada pela Rainha Mary e na sequência a "Chacone" para cordas em Sol menor, na qual o coro dança uma coreografia representando a epidemia de varíola. A Rainha morre. Retorna a introdução da "The Funeral of Queen Mary II", voltando ao cortejo fúnebre e terminando com coro final do Funeral da cantata fúnebre (MARON, 2018, p.33).

São Paulo, 01 de abril de 2015, recebemos uma mensagem do diretor via rede social, Facebook, com instrução para o início do espetáculo: 
Oi Crianças, estou enviando algumas imagens de pinturas de Caravaggio para vocês darem uma estudada. Em alguns momentos da peça, minha ideia é congelar e fazer alusão a essas cenas pintadas por ele (Paulo Maron, rede social facebook).

As "crianças" que o Diretor Paulo se refere carinhosamente,
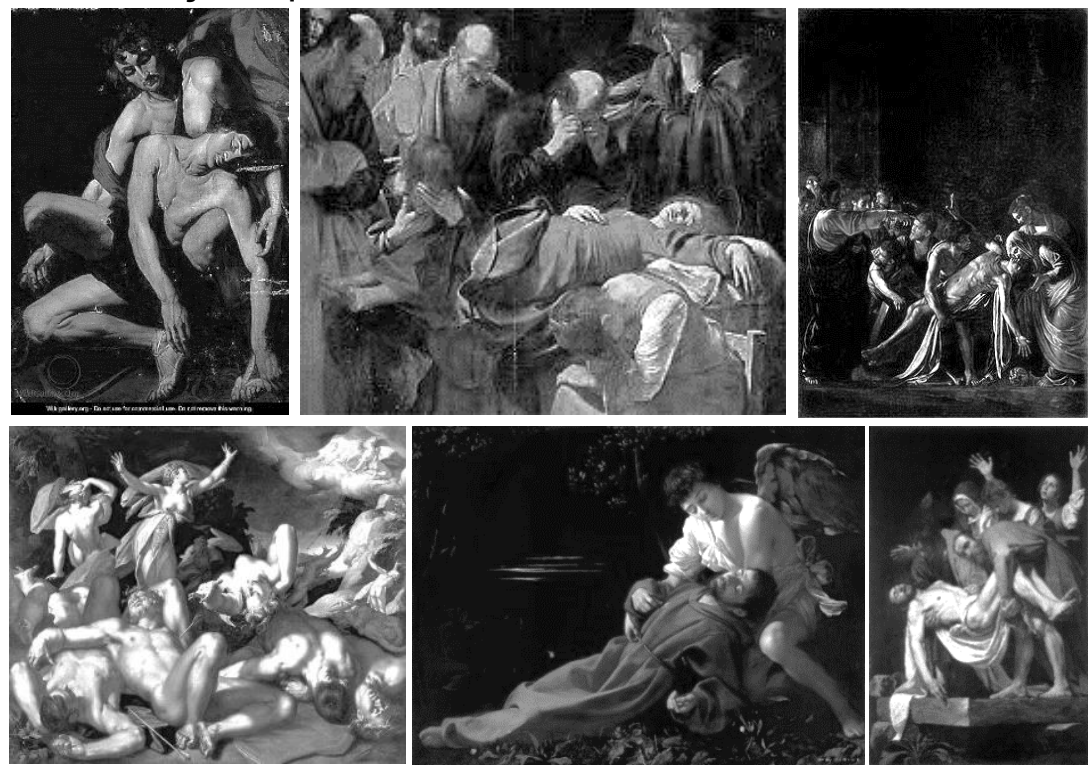

Imagem 3 - fonte: internet

somos Renata Matsuo e Wesley Fernandez. Pelas imagens recebidas percebi que essa montagem teria um "tom" escuro e dramático, o que contrariava uma pouco as montagens que estávamos fazendo até então. Com essas imagens como referência começamos a trabalhar o cortejo fúnebre inicial e a primeira música.

Dois anos após as nossas montagens de "The Fairy Queen" e "The King Arthur", ambas de Henry 
Purcell nós pretendíamos, mais uma vez, entrar no universo musical e dramático de Purcell. Todavia me restavam apenas duas alternativas, "Dido e Aeneas" e "A Tempestade" (MARON, 2018, p.32). 


\section{Paulo Maron}

3 de junho de 2015

Pois é gente, vcs estão fazendo parte desse processo e vendo que será um belo espetáculo. Não quero que o NUO seja visto como um grupo que só faz comédia...quando perguntarem sobre isso digam que é um espetáculo tocante e sensivel que as pessoas não vão sair rindo, mas tocadas e felizes por ver um espetáculo muito lindo, porque ele será.

E afinal de contas será que se fosse uma ópera de puccini ou verdi as pessoas perguntariam se é drama ou comédia? Vamos assumir o que estamos fazendo; o importante pra mim é que vcs estejam curtindo e convidando as pessoas e se elas não quiserem ir por ser dramatico, então tá.

Angélica Menezes acho que alguém que so aprecia teatro de entretenimento não merece nosso espetáculo, nem é nosso público.

3 a - Curtir

*3. Andrezza Reis Eu estou dizendo que é bem diferente do que fizemos da última vez, porém está tão lindo quanto. Estou muito tocada com esta montagem, está muito linda e estou dizendo isso para todos aqueles que chamei!

3 a - Curtir

Eliane Gama Eu, particularmente, prefiro o drama e estou dizendo a todos os que convido o quanto essa montagem é profunda! Se não quiserem "pagar ver" vão perder!!! eu estou curtindo MUUUITO, apesar do pé ... talvez até me ajude a cantar "deliver us not into the bitter pains" com mais propriedade!!! $*$

3 a - Curtir

Paulo Maron

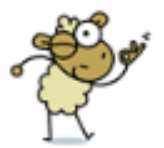

3 a - Curtir

Escreva um comentário..

Imagem 4 - Recorte facebook, grupo fechado 
As músicas são sempre cantadas no idioma original, no caso, para esta montagem em inglês, essa é uma posição do diretor, trazendo para o público as legendas durante 0 espetáculo. Fato importante de se mencionar, é que, enquanto elenco nós também recebemos essas traduções, o que não é fato determinante, mas, ajuda para compreensão e interpretação da obra. Até por isso, no roteiro você verá o nome das músicas no idioma original.

Essa cantata composta, em 1695 para o funeral da Rainha Mary II tem uma força dramática impressionante e foi isso que me motivou a pesquisar mais sobre a história dessa Rainha e a desenvolver um espetáculo sobre sua história.

O espetáculo conta a trajetória da Rainha Mary II, que reinou a Inglaterra juntamente com seu marido, o Rei William De Orange de 1689 até sua morte prematura, em 1694. Foi o único caso de um reinado inglês em que rei e rainha governaram juntos. Mary era adorada pelo povo inglês e sua morte pela varíola, entristeceu toda a Inglaterra naqueles anos (MARON, 2018, p.33).

Está claro no discurso do diretor que a ideia da companhia não é repetir uma fórmula de sucesso já conquistada, mas, sempre buscar experimentar processos novos. Henry Purcell dedicou-Ihe a Ode ao aniversário de Mary II em 1694, meses antes da morte da rainha, o que ocorreu em dezembro do mesmo ano. Em janeiro de 1695, Purcell dedicou-lhe a 
música para o seu funeral. O Diretor decidiu utilizar ambas as cantatas como eixo central. O espetáculo tem início justamente com o funeral da rainha e volta no tempo, meses antes, em seu aniversário. Mas, ao contrário de contar essa história de maneira tradicional com diálogos e música, o diretor quis um espetáculo que fosse inteiramente coreografado/coreográfico, mas desta vez, diferentemente de "Promethée" de Fauré (encenado em 2011), não com partituras corporais e sim com danças coreografadas (MARON, 2018).

O "Aniversário Morte de Queen Mary II" for mais uma possibitidade de explorar um jeito diferente de fazer ópera, música encenada. Então, apesar do embrião da ópera coreográfica ter sido no "Promethée" ewacho que se concretizowno "Aniversário e Morte de Queen Mary II". Fou muito legal essa oportunidade de ter experimentado um espetáculo inteiro cantado e dancado. já que a linguagem e expressividade cênica do teatro se dava na execucão da coreografia, on seja, na performance dancada (André Estevez). 


\section{Entrada cortejo carregando a rainha. (Chegar até quase de frente do trono)}

Eu queria contar essa históría com pouca luz e como o público fica muito proximo e se trabalha muito com o corpo, temos duas opcóes: ou se dá muita distancia, para que as pessoas vejam as formas e ai en usaria mais luz, mas, na distância de um teatro convencional, ow se vai ficar próximo, como aqui, usar pouquissimaluz, e o Caravaggio usa muito as sombras, pouca luz, os fundos saio escuros. Esse foi um dos motivos, o outro motivo, foi que logo que eu tive a ideía de fazer essa montagem a primeira imagem que veio à minha cabeca foi das pessoas segurando o corpo da rainha, e logo me veio a pintura do Caravaggio e aíewjuntei as duas coisas (Pauto Maron).

\section{Pose: fazendo alusão a pinturas de Caravaggio.}

Nos primeiros ensaios nós já experimentamos como seria a caminhada, o tempo de deslocamento e a tensão que seria imprensa para este momento. Isso é fácil porque ensaiamos no andar abaixo ao palco, logo, temos a dimensão real do deslocamento. Isso além de facilitar a vida dos coreógrafos deixa os artistas mais seguros. E conseguimos definir em 
grupo qual seria o melhor momento da música e em qual espaço do palco chegar para descer a rainha e formar as imagens que construímos juntos inspiradas nas pinturas de Caravaggio.

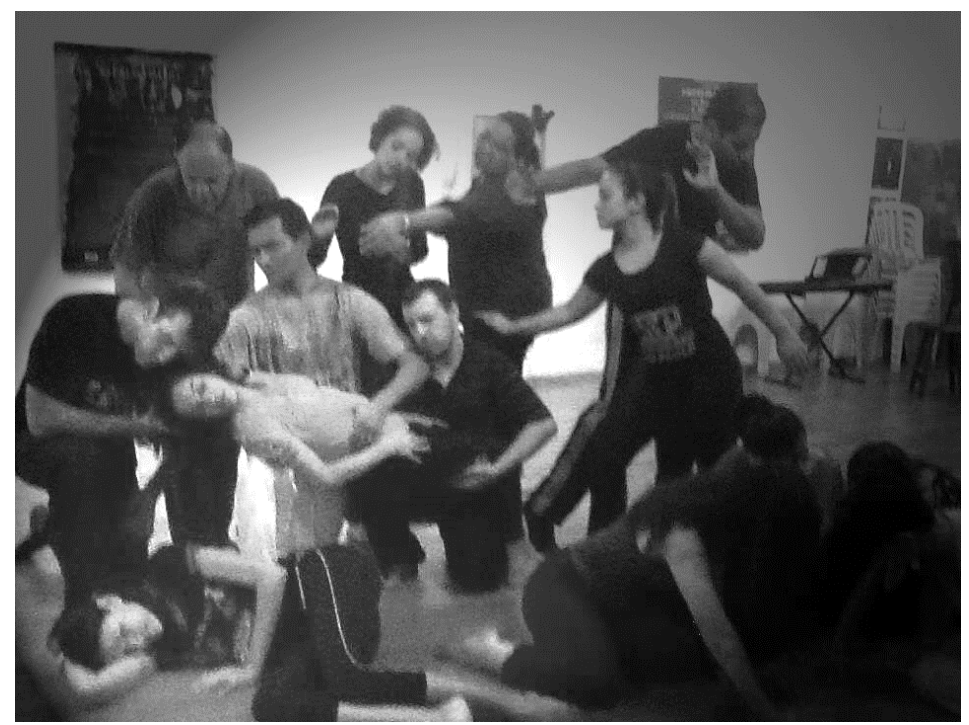

Imagem 5 - fonte: acervo NUO-Ópera Lab.

Para encontrar as qualidades do movimento dessa caminhada, nos valemos das instruções de Laban. Assim, experimentamos trazer o peso para os pés e como o tônus muscular se alterava no restante do corpo. Rudolf von Laban (1879 - 1958) nasceu na Bratislava, teórico-prático da dança criou vários centros de pesquisa com o intuito de resgatar os movimentos naturais e com isso a espontaneidade, lembrando que ele faz isso na época da revolução industrial. 
Além disso, buscava a plena vivência consciente de cada um desses movimentos, com o intuito um desenvolvimento amplo e profundo de quem faz esse movimento.

Por não aceitar o vazio existente nas peças de teatro e dança dessa época, trouxe para seu trabalho o resultado das próprias paixões e lutas interiores $e$ sociais, representadas por personagens simbólicas ou estados de espíritos puros, vividos através do movimento, utilizado da maneira mais espontânea e sempre como resultado consciente da união corpoespirito (ULMANN, 1978, p.09).

A "pose" nunca era estática, pois além da respiração pedimos para que os integrantes trouxessem tônus para o corpo, dependendo da posição que cada um estivesse, mas, principalmente para a região do abdômen. Isso veio como resultado também da preparação pois fizemos aulas de dança moderna, e nos inspirando na técnica de Martha Graham, (1894 - 1991) dançarina e coreógrafa moderna americana que além de criar uma nova técnica de dança, reformulou o estilo de dança norte americano.

As ideias e sentimentos são expressos pelo fluir do movimento e se tornam visíveis nos gestos, ou audíveis na música e nas palavras. A arte do teatro é dinâmica, porque cada fase some quase que imediatamente após ter aparecido. Nada permanece estático é impossível realizar um exame demorado dos detalhes. Na música, um som sucede o outro e o primeiro morre antes que seja ouvido o seguinte. As 
falas dos atores e os movimentos dos dançarinos estão todos num fluxo dinâmico continuo, interrompido apenas por pausas breves, até que finalmente cesse de todo ao terminar o espetáculo (LABAN, 1978, p.29).

Laban teorizou a partir de suas práticas e reflexões, me pergunto aqui se ele também não estaria dizendo como fazer pesquisa, uma vez que essa fala dele conversa com as ideias de Ingold que apresentei no início do texto. As coisas em fluxo, a impermanência, o cotidiano ...

O movimento é o principal meio que o ser humano tem para sua expressão (LABAN, 1978, p.60). 


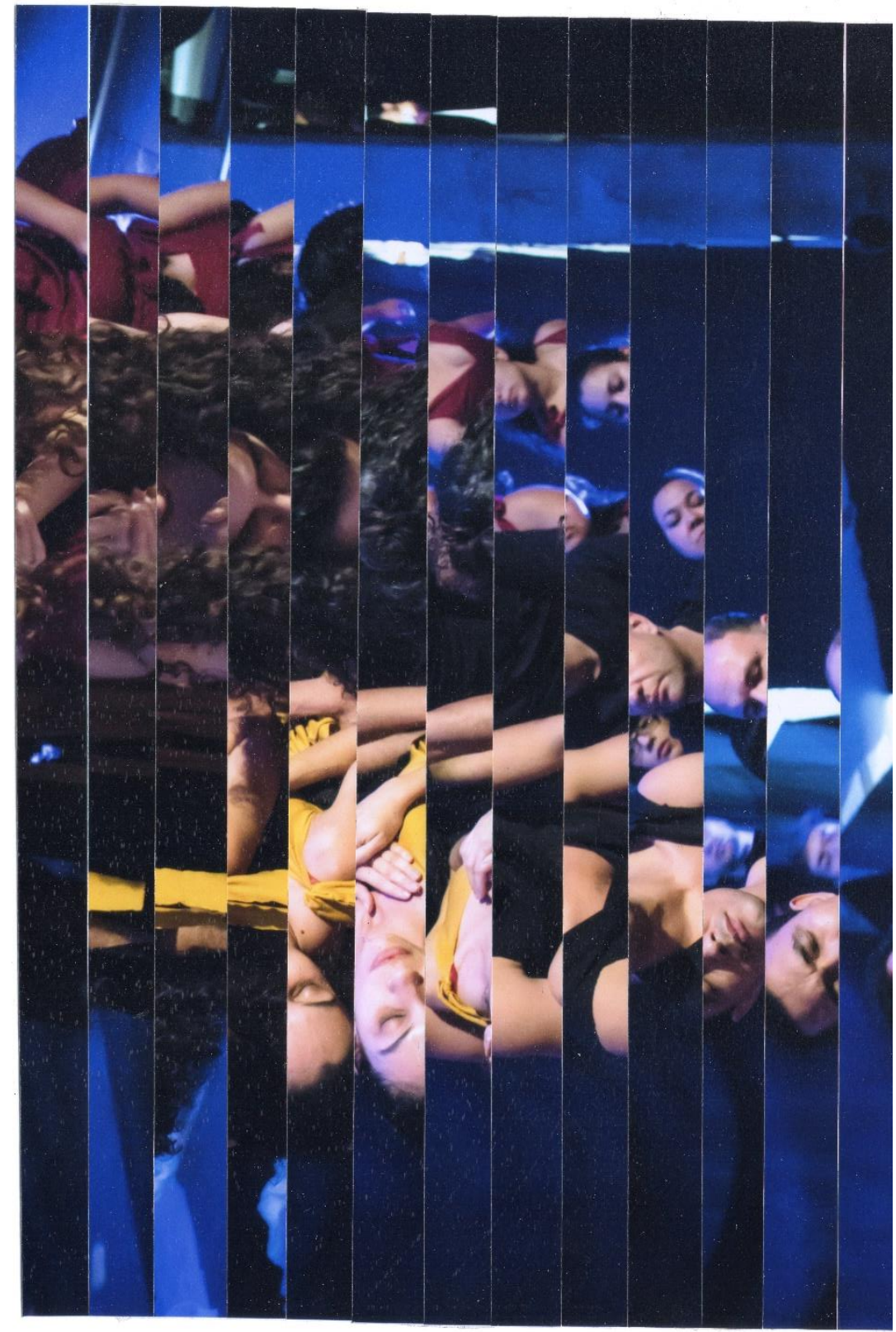

Imagem 6 


\section{A rainha é carregada até sua "tumba" (deixa: no "Yet" da música).}

A cena está acontecendo. De repente, o movimento do solista de othar para o maestro para iniciar seu solo, interrompe o fuxo do que estava acontecendo, quebra a cena (Pauto Maron).

Ao longo do percurso de cada montagem os artistas foram aprendendo a estar em cena sem a presença do maestro. $O$ diretor ${ }^{9}$ explica que existem entradas complicadas, mas que o grupo aprendeu a sentir e a respirar junto com a orquestra. "A gente (orquestra) vai atrás deles (cantores) ", explica o diretor, ele segue esclarecendo que o delay, ou o atraso que acontece do som da orquestra para chegar no palco existe em todos os grandes teatros e daí a necessidade de ter alguém, que esteja à vista de todos e muitas vezes com um foco de luz, para marcar o tempo. No espaço, que é nosso, por ser menor este problema não acontece o que nos dá liberdade de

${ }^{9}$ Diretor e Maestro nesse caso, NUO-Ópera Lab. são a mesma pessoa, Paulo Maron. Geralmente essas funções são executadas por pessoas diferentes o que leva a setorizar e hierarquizar as funções. 
fazer "certas sutilezas de dinâmica que seriam impossíveis em espaços maiores" (Maron, 2018).

O fato de a orquestra não estar mais em um fosso, estar fora do campo de visão dos cantores, foi uma decisão arriscada: os cantores não me veriam reger e eu não os veria. Apenas sentiríamos e ouviríamos as respirações. Deu certo: percebemos que a confiança que cultivamos durante anos nos possibilitou esse feito. A orquestra e o maestro saem literalmente de cena, ela é só ouvida e não vista, nem pelo público nem pelos cantores (MARON, 2018, p.82).

Durante essa canção, da qual disponibilizo a letra abaixo, escolhemos yet como sinalizador, como deixa para a coreografia. O movimento nesse momento consistia em descer a rainha do cortejo para formar a imagem inspirada nas pinturas do Caravaggio. 


\section{Funeral Queen Mary II}

Man that is born of a woman

hath but a short time to live,

and is full of misery.

He cometh up, and is cut down like a flower;

he fleeth as it were a shadow,

and ne'er continueth in one stay.

In the midst of life we are in death:

of whom may we seek for succour, but of thee, O Lord,

who for our sins art justly displeased?

Yet, O Lord, O Lord most mighty,

O holy and most merciful Saviour,

deliver us not into the bitter pains of eternal death.

Thou knowest, Lord, the secrets of our hearts;

shut not thy merciful ears unto our pray'rs;

but spare us, Lord most holy, O God most mighty.

O que me marcow no processo for a carga dramática que o grupo conseguiu construir ensaio por ensaio. Talvez tenha a ver com a respiraça e a poética do movimento (Angética Menezes).

Essa fala da artista Angélica, me remete ao processo que fizemos e a fala de Laban citada a cima. 
O corpo diz o que as palavras não podem dizer (Martha Graham, 1991).

Acrescido disso durante a preparação corporal a preparadora ao questionar/refletir sobre a lição de Feldenkrais feita com o grupo diz:

Onde sobram patavras faltam sensaçós (Marítia Velardi - caderno de campo).

\section{Meninas: começam o movimento de um lado para o outro.}

A Imagem inicial inspirada pelas imagens de Caravaggio é desfeita e os meninos carregam a rainha morta para o canto do palco onde tem um véu branco. 


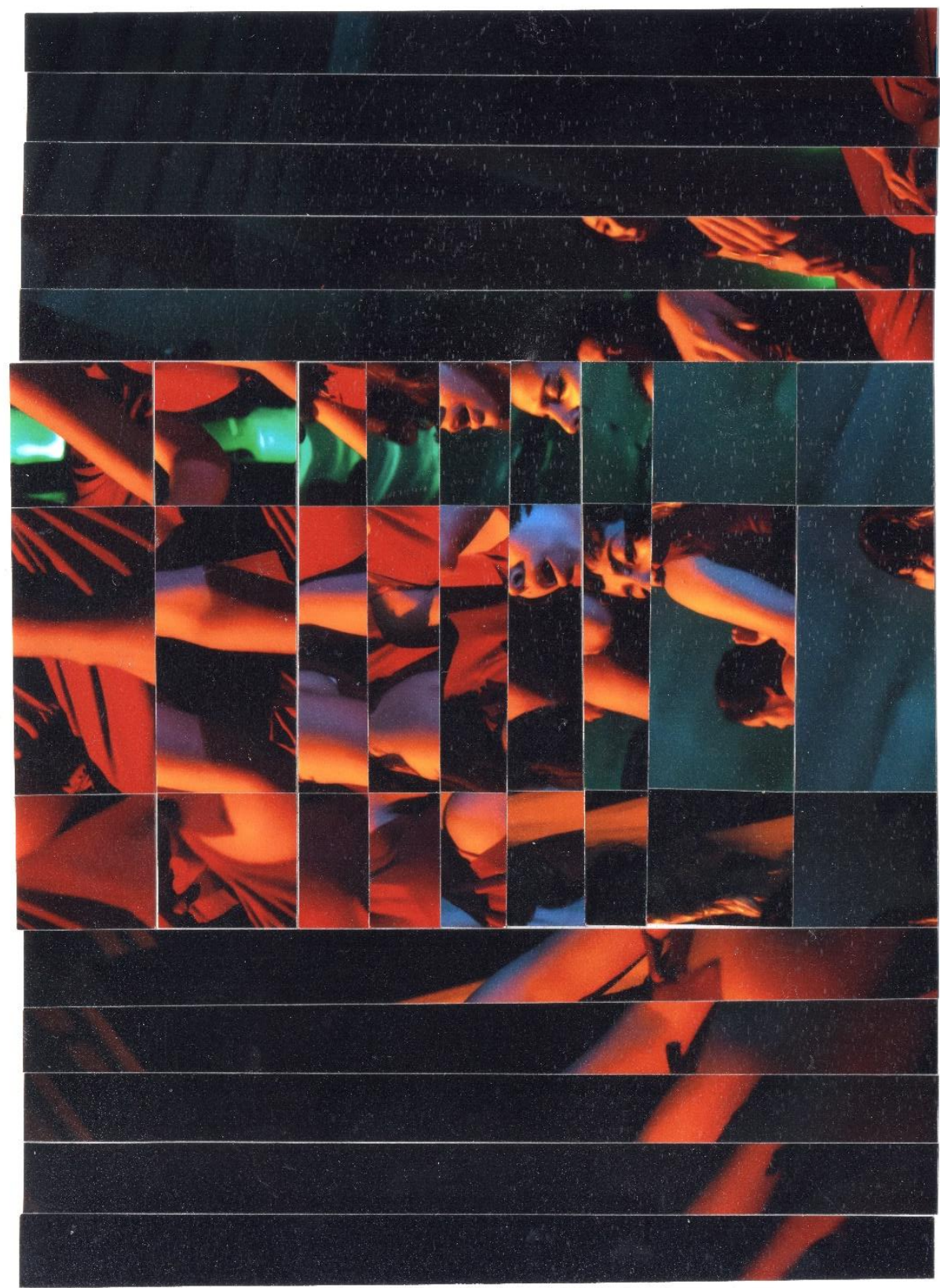

Imagem 7 


\section{No último "deliver us not" levantar e ir para trás}

(canto esquerdo do palco).

Meninos parados em linha, um ao lado do outro, meninas do outro lado do palco, em grupo, fazendo a partitura corporal com as mãos e braços. Fim do lamento.

\section{Cena II - CANÇÃO DA MANHÃ}

O Rei, interpretado por Pedro Ometto, canta a saudade de não ter mais sua rainha pela manhã.

\section{O Rei canta - solo do Pedro. Durante a canção, todos parados.}

Outro motivo que me marcou, for o papel que o Pauto me confiou, o Rei Wittiam, que me permitu explorar uma imensa gama de sentimentos es por consequência, de movimentos corporais (Pedroometto).

Sentado em uma cadeira ele faz movimentos lentos com a indicação de: sentir os pés bem apoiados no chão e os ísquios apoiados na cadeira. Ele encontra os spirals e contractions que trabalhamos na preparação corporal ao longo do processo. 
De acordo com a técnica de Martha Graham, o movimento é criado a partir de três lugares: 1) a ação de contração e liberação (contraction and release), 2) a pélvis e 3) o eu interior emocional. O uso repetido da contração e da liberação provoca uma energia rítmica aos movimentos nessa técnica. Os exercícios podem ser feitos sentado, deitado e em pé. Para a Dançarina e coreografa Graham, o tronco e a pélvis, dessa maneira, são o foco central do movimento, enquanto os braços e as pernas se movem em harmonia com a coluna. $A$ série de exercícios conhecida como spirals (espirais), quando feita sentada na quarta posição, é um excelente exemplo de como a pélvis, enraizada/apoiada no chão e aproveitando toda a energia dessa proximidade/apoio é um excelente caminho para explorar o potencial de movimento que o tronco possui. Portanto, a pélvis é a primeira parte do corpo a se mover. Durante a preparação corporal tivemos a oportunidade de experimentar todos esses exercícios.

\section{Cena III - LAMENTO}

\section{Rainha sai de seu "casulo" e vai deslocando por trás do tecido.}




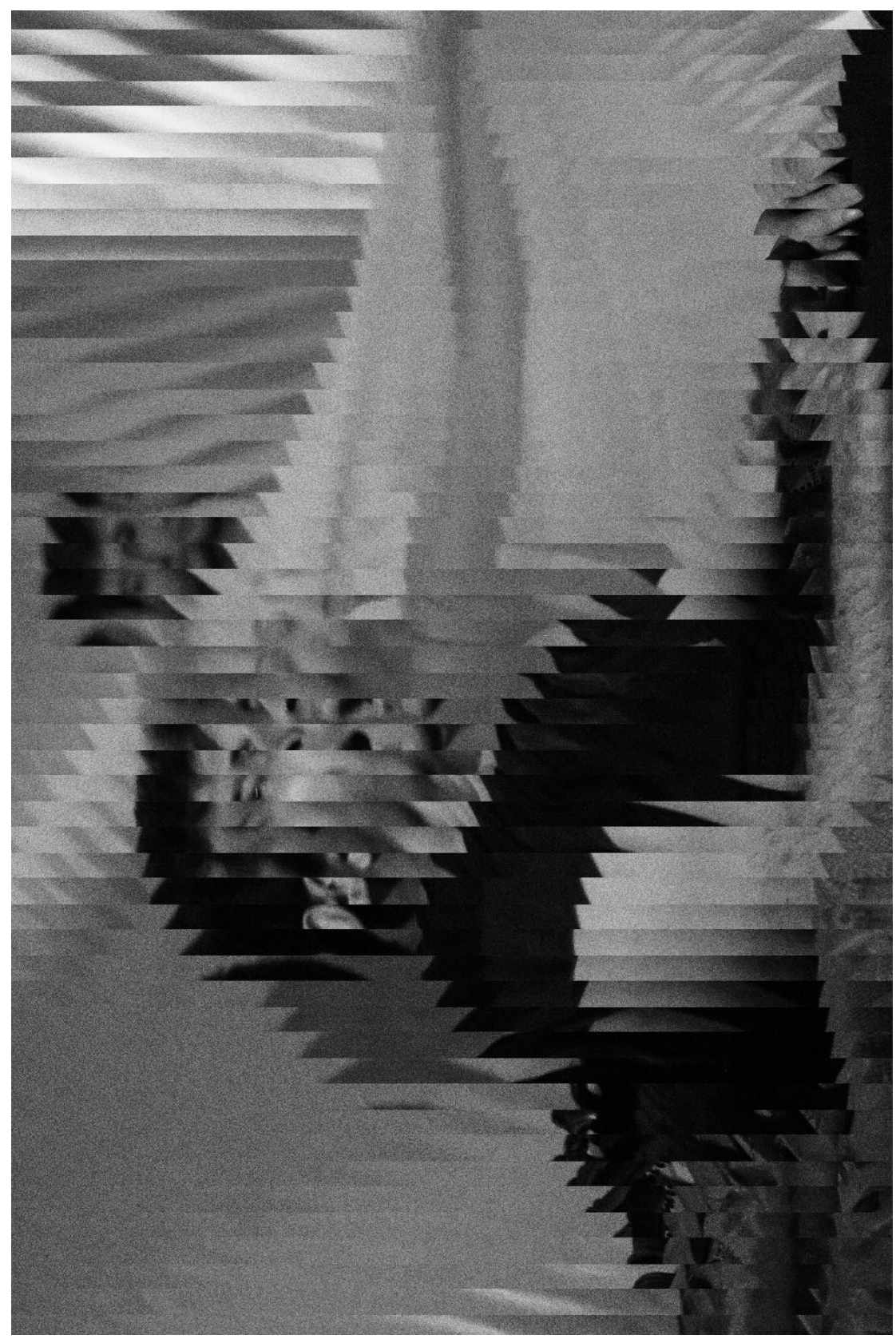

Imagem 8 
Contato. Essa era aquela hora de transicão em que a Rainha "saia" do mundo dos mortos, para passar pela vida (aniversárío). Para mimé como se ela não tivesse vivido o aniversárío. Era como uma lembranca, um flashback. A "reatidade" dela é que estava morta mesmo. $O$ mundo real dela era esse, atrás do tecido. Outro ugar que não o real (Angélica Menezes).

Não teria melhor maneira de contextualizar essa fotografia do que a fala da artista Angélica. Que não foi dita para isso, ou seja, a Angélica, ao me trazer esse relato não quis explicar a imagem, mas, estava sim descrevendo o que ela sentiu ao fazer essa cena.

\section{Seu lamento chega até as costas do trono do rei.}

Com certeza foi o projeto mais denso que tive o prazer de fazer parte. Todo o trabalho corporal ideatizado for de extrema importância para a montagem. Lembro, com clareza, das etapas de preparacaio e conhecimento do corpo, utitizando movimentos que derivam da técnica Feldenkrais e também de movimentos elaborados pela dancarina Martha Graham, que, com certeza até hoje me ajudam nas óperas em que faco parte (Andrezza Reis). 
“... que com certeza até hoje me ajudam nas óperas em que faço parte" essa fala me chama a atenção, e quando eu pergunto para a artista Andrezza: Por que e como essa experiência te ajuda até hoje?

Me ajudam principalmente na movimentacão no palco. Inclusive, participei de uma cena em que minha personagem morria. Eutive a ideia de usar o "relógio pélvico" inspirado em Feldenkrais que a Maritia nos ensinow, e tudo ficou muito mais orgânico (Andrezza Reis).

Enquanto artista da cena ela teve que encontrar dentro do seu próprio repertório a solução para a cena e escolheu usar o que experiênciou dentro do NUO-Ópera Lab. Quando pensamos em encontrar nossas próprias epistemologias e as repostas para nossas investigações artísticas de como responder as questões que se mostram no nosso cotidiano, o NUO-Ópera Lab. se mostra um espaço para que isso aconteça. Com isso Boaventura Souza Santos (2008) é logo lembrado por mim, pois este autor ajuda a compreender que são nos encontros locais, em determinadas culturas em suas particularidades que isso acontece. 
A artista Andrezza cita Moshe Feldenkrais (1904 - 1984), israelense e dentre suas possibilidades como multiprofissional ele foi: engenheiro, matemático, físico, (trabalhou com o casal Joliet-Curie, ganhadores de um Prêmio Nobel em física), judoca (importante salientar que foi um dos primeiros europeus a receber a faixa preta na modalidade) e para aperfeiçoar seu trabalho, que mais tarde se solidifica como um método, ele estudou também anatomia, fisiologia, desenvolvimento infantil, evolução, psicologia, uma série de práticas de conscientização orientais e outras abordagens somáticas, sem contar o fato de que ele era um observador do mundo (BOIS, 2010).

A Inglaterra o acolhe durante a Segunda Guerra Mundial, e é neste país que Moshe Feldenkrais escreveu seu primeiro livro sobre o assunto. Sua principal motivação para criação de seu método foi um problema pessoal, uma lesão no joelho em que a cirurgia não seria garantia nenhuma de sucesso. A partir daí sua dedicação segue no sentido do desenvolvimento da capacidade de equilíbrio do corpo no espaço como instrumento de busca e realização do potencial individual como fator de integração e desenvolvimento das habilidades humanas de julgar, discriminar, generalizar, pensar abstratamente e imaginar (BOLSANELLO, 2010). 
Nesta área, arte e saúde, ele formulou parcerias internacionais trabalhando com: Peter Brook (1925), Ben Gurion (1886 - 1973), Heinz Von Foster (1911 - 2002), Karl Pribham (1919 - 2015), Margaret Mead (1901 - 1978) entre outros. Vale ressaltar que nesta mesma época e diante de contextos parecidos Moshe Feldenkrais tem como contemporâneo Rudolf Laban, que mescla suas pesquisas entre o teatro, a dança e o cotidiano (BOLSANELLO, 2010).

Eu costumo deixar claro que o ponto do meu trabalho é levar a consciência em ação, ou a capacidade de fazer contato com o próprio esqueleto e músculos e com o meio ambiente, praticamente ao mesmo tempo (FELDENKRAIS, 1980, p.77 - tradução nossa).

O Método criado por Moshe Feldenkrais, Método Feldenkrais, faz um convite a curiosidade, no sentido de sair do automatismo cotidiano, revelando novas possibilidades de organização, descobrindo o ritmo pessoal e percebendo a utilização do esforço em cada movimento, observando as sensações bem como o espaço ao redor. Ser capaz de escolher sua própria ação e durante a ação ter a possibilidade de reverter a ação em qualquer estágio. Ser dono do próprio movimento. Assim, os principais objetivos do Método Feldenkrais são: aumentar a vitalidade geral, reduzir desconfortos internos derivados de tensões ou esforços 
difusos e aplicar a energia pessoal no trabalho criativo de descobrir e realizar a individualidade pela aquisição de um novo repertório de respostas. Essas novas respostas auxiliam a pessoa a explorar e realizar, de modo gradativo e continuo, o próprio potencial (BOLSANELLO, 2010). A aquisição de um novo repertorio de respostas permite então, novas possibilidades de movimento para criar e/ou expressar 0 corpo do personagem com o menor gasto enérgico na execução deste movimento. A consciência pelo movimento enquanto o movimento acontece. Mais uma vez me vejo refletindo sobre o método de pesquisa e me inspiro, nessa fala, para fazer o trabalho já que vou tomando consciência do trabalho enquanto o escrevo.

Eu me lembro bem dos movimentos que fizemos para nos familiarizar com a "Ida até o chão", fazendo com que o movimento de "sentar e levantar" fossem reatizados da maneira mais orgânica possivel. Esta etapa principalmente me ajudow muito a criar uma relação mais próxima com meu corpo e com os diversos planos que posso explorar através dele (AndrezzaReis). 
A movimentação cotidiana é uma das inspirações para as várias posições e situações que o Método Feldenkrais propõe, por exemplo, sentar, levantar, andar entre outros. Com o intuito de que a pessoa se familiarize com as atitudes de: explorar, observar e buscar novas alternativas de ação.

Foi um dos processos, no NUO-Ópera Lab. que me fizeram conhecer mais ainda o meu corpo e não tenho dividas que ainda tenho as memórias corporais as quais pude vivenciar neste projeto (AndrezzaReis).

A ideia central está em modificar o ritmo e a sequência de execução para que a falta de familiaridade no modo de fazer revele que a pessoa não tem consciência de muitos aspectos de si própria. Assim nos momentos em que a pessoa tem a oportunidade de estar nessa situação - de explorar, observar e buscar novas alternativas - ela se estranha tem as possibilidades de ficar: desconcentrada, desnorteada ou interessada. Dessa maneira, a mudança em cada ação simples, modifica a percepção de si, podendo criar novas maneiras de apreender, de condução de si, no modo de agir e interagir com as pessoas, situações, ambientes e em cena ou para a cena (BOLSANELLO, 2010). Mais uma vez me pergunto de Feldenkrais também não nos ensina a fazer 
pesquisa, pois durante o processo, estive muitas vezes nesses estados - de explorar, observar e buscar novas alternativas - esses são os turning points da pesquisa.

o processo corporal ajudow muito, também, na parte interpretativa da montagem, porque com o movimento corporal foi possivel trazer expressóes e criar também novos movimentos que iam de acordo com cada uma das músicas (AndrezzaReis).

\section{MENINAS: durante 0 lamento, movimentos pequenos $(6,12,9,3)$ na bolota.}

O "6, 12, 9, 3" são a referência para uma das lições de Feldenkrais que fizemos que inspirou essa movimentação. Mais precisamente a Lição 6 "Diferenciação dos movimentos pélvicos por meio de um relógio imaginário" do livro "Consciência pelo movimento". Lembro de estar deitado no chão e ouvir as instruções:

Sinta sew corpo apoiado no chão. Perceba sua respiração, não mude nada, apenas sinta [...]. Flexione os joethos apoie os pés no chão. Escotha a distância entre um pé e o outro e escolha também a distância mais confortável entre os pés er $\sigma$ quadrit. Levante o quadrit do chão, 
usando os misculos das costas, formando um arco na sua lombar. Descanse... imagine um círculo na região um pouco a cima do sew cóccix. Este círculo é um mostrador de relógio onde 6 horas está na direção do cóccix, 12 horas na direção da lombarl...) (Maritia Vetardi - caderno de campo).

Essas instruções, com um tom de voz doce e suave, que vai nos permitindo desbravar caminhos do corpo que antes não haviam sido explorados e/ou nunca antes foi dada atenção. $A$ lição segue com várias instruções de respiração e percepção do quanto de tensão muscular é aplicada para executar os movimentos.

\section{[...] 3 horas está do lado direito e 9} horas do lado esquerdo. Encontre esses pontos e explorem eles indo das 12 horas para as 3 horas, das 3 para as 6 horas, das 6 horas para as 9 horase chegando as 12 horas. Repita isso algumas vezes percebendo o caminho[...] descanse[...] (Maritia Velardi-caderno de campo).

A lição segue, mas o que eu percebo é que, quanto mais a minha percepção se acentua, mais os meus limites de entendimento se expandem. E a cada lição um novo lugar no meu corpo é descoberto e/ou acessado de um jeito mais 
rápido e/ou diferente, ou seja, meu repertório se expande, o que é ótimo para um artista. A ideia é entender o movimento e compreender as partes do corpo que participam, mas, sempre com o compromisso de voltar ao todo. Mais uma vez, fico encantado, em perceber como isso se aplica também, a ideia de método/pensamento/ação para/na investigação radicalmente qualitativa. Portanto, olhamos para as partes desse trabalho de forma separada, mas, nunca esquecendo que essas partes, fazem parte de um todo. Logo adotamos os marcadores do relógio, ou seja, os números como indicadores do movimento.

\section{MENINOS: parados em frente ao tecido branco.}

Enquanto a rainha fazia seu solo (Lamento) atrás de um véu branco os meninos estavam na frente, parados. Lembro de sentir a voz da artista Angélica cantando remember me e o toque de suas mãos e corpo sobre o meu, mas, ainda existia uma separação, o tecido. Isso porque, ela estava morta. Para mim em cena a sensação de conexão com alguém que não estava mais presente fisicamente. Faço a ligação dessa cena com as falas de todos os autores que escuto e busco um diálogo aqui. 
Bourdiew, vai dizer na Sociologia: naio tem história verdadeira. O fato histórico é sempre um fato social, porque depende de quem conta. Sempre! Quando você traz um evento de um tempo passado, é importante contextuatizar, porque se não a gente acha que está lidando com fato histórico e a gente está lidando com fato social.

Então o teu texto tem que estar recheado de: para esse autor que é fulano fez isso e aquito e traz a partir dessa perspectiva. Porque se não a gente vai comecar a achar que isso é a verdade e talvez não seja. Você está lidando com fato social e não com a história. Você está lidando com o que importa e o que sobra (Marítia Velardi, 2017, arguicão quatificacão).

Assumo aqui que estou o tempo todo lidando com fatos sociais, e busco contextualizar os autores que cito à medida que cito, por isso também, trago seus nomes completos ao invés de fazer a citação clássica apenas com o sobrenome. 


\section{ANIVERSÁRIO}

\section{MÚSICA “COME, COME” (TUDO MODIFICADO)}

o elencoépronto, ele é receptivo e ele é entregue. Qualquer proposta que a gente propóe eles agarram. São muito abertos. Então isso fez com que euficasse com menos medo. Afinal, ew nunca tinha feito nada desse tipo. Eu sempre trabathei mais como professora do que como coreógrafa. As coreografias que en elaboro são construcões feitas com os meus alunos a partir das aulas que eu ministro (Renata Matsuo).

O "tudo modificado" aqui se deu porque dias antes da estreia percebemos que a movimentação estava excessiva para o nosso espaço. Embora, já estivéssemos familiarizados com nosso espaço, foi quando fizemos os ensaios corridos, ou seja, do começo ao fim sem parar, que percebemos que a proximidade do palco com a plateia pedia uma movimentação menor em dois sentidos, tanto no sentido do tamanho dos movimentos quanto na quantidade de movimentos, então enxugamos as coreografias. Além, é claro, de buscar a dramaturgia proposta pelo diretor. 
Como na mensagem vista, o grupo se comporta de maneira

\section{Paulo Maron}

10 de junho de 2015

Oi pessoal, queria dizer umas coisas pra vcs.

Ontem vcs viram uma série de alterações que fizemos, sobretudo no aniversário. Mesmo faltando dias para a estreia, eram importantes esses arremates e até mudanças mais profundas para chegar a dramaturgia de movimentos que eu pensava. Vcs como sempre se portaram de maneira muito profissional, confiando e se entregando sem questionar. Foi ótimo o ensaio de ontem, na quinta vamos fazer duas vezes corrido. Vou mandar em seguida um link com a música da Chacone onde fazemos a "dança da varíola" e daí explico o que vcs devem prestar atenção. Cada dia vcs mergulham mais nesse espetáculo. O público vai gostar muito do que vão ver, com certeza.

abraços

으 Curtir

Marilia Velardi, Eliane Gama e outras 9 pessoas

Escreva um comentário

\section{Comentar}

Visualizado por 25

acolhedora e confiante mediante as mudanças feitas. Foi daí Imagem 9 - Recorte facebook, grupo fechado

também que surgiu o roteiro feito em grupo para ajudar a localizar as mudanças dentro do espetáculo todo.

Foi uma das montagens em que mais sent o NUO-ópera Lab. como um grupo coeso e unido, o que é sempre muito gratificante (Pedro Ometto).

Era possível fazer isso também porque tínhamos uma estrutura nossa, ou seja, nosso espaço. O diretor fala dos desafios que o grupo havia enfrentado até então justamente 
por conta de estruturas físicas que sempre esbarram nas estruturas políticas.

Foi um mergulho no vazio. Nós não sabíamos o que aconteceria com o público, nem como nos sentiríamos noutro lugar. Foi um período difícil emocional e financeiramente. A dificuldade não era apenas conseguir datas nesses espaços, mas pagar os custos. Além disso, nós ficávamos totalmente à mercê dos diretores de programação desses teatros, que visam lucro, portanto, muitas vezes quem pudesse pagar mais teria a preferências na escolha das datas. Uma das coisas que nos motivou a lutar para ter nosso espaço próprio foi justamente não sermos mais vítimas dos programadores de teatro. Termos a liberdade de escolhermos quando e como realizar nossas produções, sem qualquer intromissão ou impedimento (MARON, 2018, p.49).

Assim, essa liberdade de fazer o que e como quiséssemos faz parte dessa montagem também. Isso demonstra a necessidade artística de Ópera Laboratório que o NUO-Ópera Lab. assumiu com o espirito de "sair da forma familiar de fazer ópera e correr riscos" (MARON, 2018).

Assumimos o NUO como NUO-Ópera Laboratório, justamente por essa vocacão de que todo semestre o Paulo propõe um novo experimento. Isso é muito legal, desafiador e enriquecedor para mim como artista/professor/pesquisador. Assim estar neste espaco podendo experimentar outras 
formas e linguagens, é sempre legal. $O$ "Aniversário e Morte de Queen Mary II" foi mais una possibitidade de explorar um jeito diferente de fazer ópera, música encenada (André Estevez).

\section{Parte 1: dueto Angélica e Pedro.}

E antes de falar o ser humano dançou...

Dancar e cantar ao mesmo tempo nunca é assim um piquenique para mim, mas, as coreografias na produção foram tão orgânicas que não me lembro de ter sentido qualquer incómodo, pelo contrárío, tudo funcionow de forma bem redonda (Pedro Ometto).

Lembro-me de ouvir durante os ensaios os meninos comentando que cantavam melhor quando faziam os giros da coreografia e giravam melhor quando estavam cantando. Isso demonstra como tudo estava em conexão, amalgamado. 


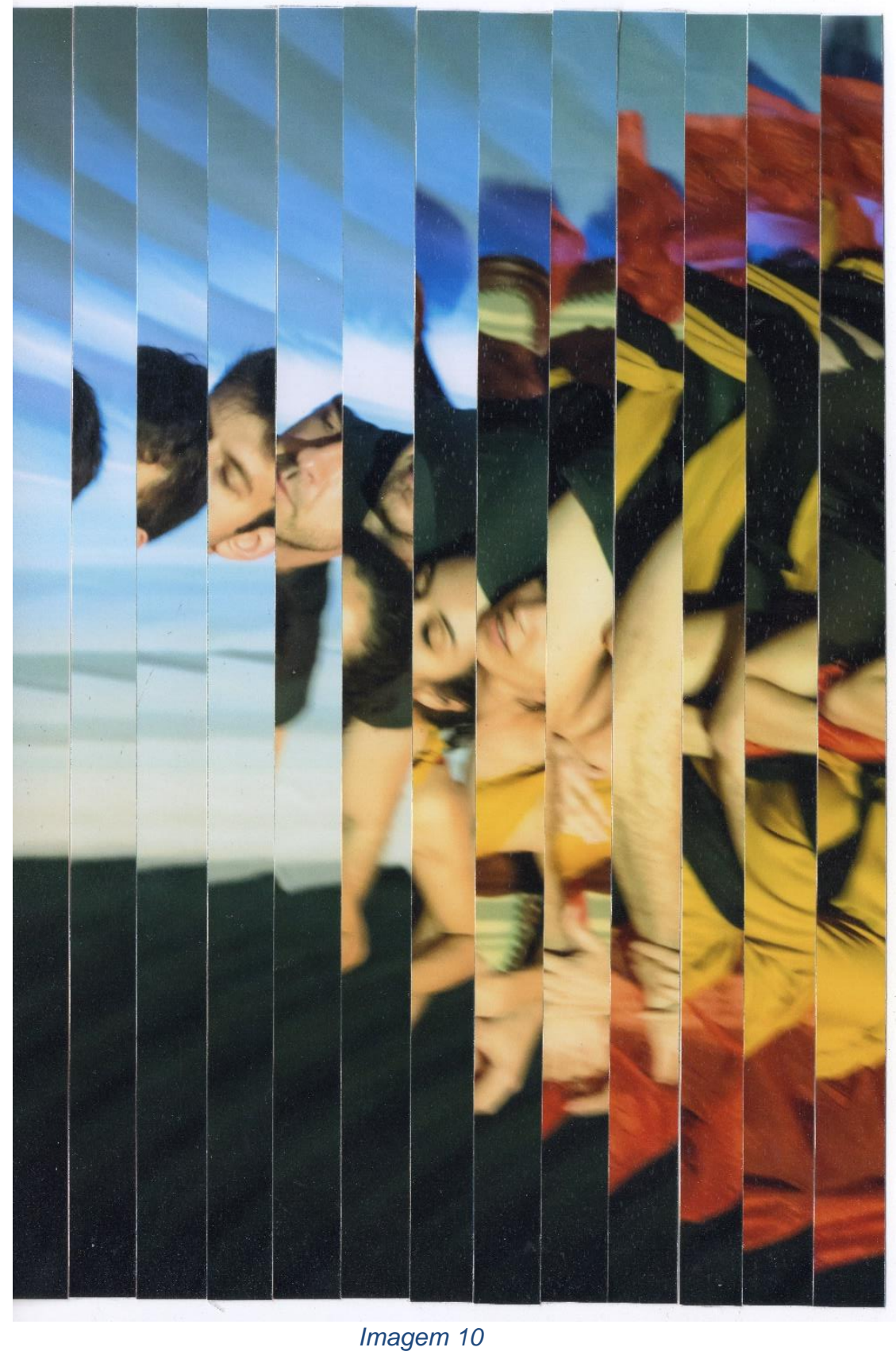


Eu fiquei pensando sobre a questão chave, do conceito que você traz do Paulo Maron, dessa dissolucaio dos papeis, desse novo diálogo entre danca, teatro e ópera. Um cantor, mas, ele danca, por exemplo. Se realmente isso é possivel e se isso acontece na formacaio desse corpo e na formaça dessas obras. Se é possivel se perder nessa hibrides. Porque as vezes, o que se vê é um trabalho, mesmo de danca contemporânea que usa um texto, as coisas perdem a conexão fuida. Por exemplo, o dancarino para a cena para falar o texto. Eu acho que isto está na questão do sew conceito e da sua borda sobre ser ópera coreográfica (Vanessa Macedo, 2017, arguição qualificação).

A palavra dança, em vários idiomas - danza (italiano), dance (inglês), tanz (alemão) - tem origem da raiz "tan", que em sânscrito significa tensão (GARAUDY, 1980). Danse do Francês danser, do Frâncico dintjan, "mover-se de um lado para outro". No Congo, o verbo, tanga é utilizado para designar respectivamente "escrever e dançar" (PEREIRA, 2010, p.74). Assim, dessa "tensão" corporal e desse "moverse de um lado para outro" deu-se início às linhas que foram "escritas e dançadas" pelas letras, pelas "tensões" e inquietações que nos atravessam da dança como espetáculo 
autônomo e/ou como uma das partes do espetáculo operístico.

\section{Meninas do lado esquerdo: círculo.}

"Dançar é, antes de tudo, estabelecer uma relação ativa entre homem e a natureza, é participar do movimento cósmico e do domínio sobre ele" (GARAUDY, 1980, p.14). E esta relação da dança com a vida, que Roger Garaudy (1913 - 2012), filósofo francês traz em seu livro "Danser sa vie" (Dançar a vida) escrito em 1973, uma discussão sobre os caminhos percorridos pela dança, objetivando retomar 0 seu renascimento no século XX. Ele discorre sobre a dança na linha do tempo, e dialoga com a filosofia que nos permite compreender socialmente. Ele ilumina, dizendo que a dança parece estar enraizada na humanidade desde que esse ser humano pré-histórico aprendeu a desenhar nas cavernas, pois registrava aquilo que julgava importante. A dança está ligada aos momentos essenciais do ser humano como: caça, plantio, colheita, vida, morte, religião, entre outras possibilidades que eram encontradas na época para expressar pedidos e/ou agradecimentos (GARAUDY, 1980; FARO, 1986). Ou seja, o ser humano relaciona-se com a dança desde sempre. É dessa maneira orgânica que os 
processos resultaram nas coreografias como o artista Pedro Ometto traz na fala dele.

Dança e música estão ligadas, especialmente do ponto de vista dos rituais, uma vez que a dança acontecia ao som e compasso de música. Seja na dança da Índia, África, Egito ou de onde for, ela era acompanhada de música e/ou a música era acompanhada de dança.

"A dança não é apenas expressão e celebração da continuidade orgânica entre homem e natureza. É também realização da comunidade viva dos homens" (GARAUDY, 1980, p.17). Durante séculos, as manifestações de dança eram detidas pelas cortes - religiosas ou monárquicas -, ou eram privilégio somente dos homens. Com o tempo, lentamente, o povo foi tendo acesso às exibições de dança para, mais tarde, transformar-se em teatro popular (FARO, 1986); mas até chegar a este ponto de teatro popular, importantes fatos aconteceram.

\section{Meninos do lado direito: andam em fila para o outro lado.}


A danca tambémé um modo de sentir a música e expressar a música. A danca é a maneira mais intuitiva de se conectar com a música. $O$ movimento do corpo se conecta com a música (André Estevez).

"A dança é a linguagem escondida da alma, do corpo" (Martha Graham, 1985).

Antônio José Faro (1933 - 1991), brasileiro, formou-se em direito pela Faculdade Nacional de Direito do Rio; crítico de dança de periódicos Ópera de Londres, Ballet News e Ópera Magazine de Nova York e Ópera de Paris, além dos jornais $O$ Globo e Jornal do Brasil, traz um panorama de como surgiu a dança e de seu desenvolvimento até a atualidade. Ele revela as características básicas do desenvolvimento e do uso da dança como arte, como ritual e como entretenimento. Além disso, apresenta uma forma de ver o trajeto que a dança fez. De acordo com o autor, a dança começa nos templos, passa pelas aldeias, pela igreja, a praça, o salão, até chegar aos palcos. Ele ressalta que as danças de salão são todas aquelas que passaram a fazer parte da vida da nobreza da idade média em diante. 
Entre os séculos XIII e o XV, desenvolveram-se as danças rústicas entre o povo. Acredita-se que sejam produto ou sobrevivência das antigas danças pagãs e das danças da corte. Isso porque, anteriormente, a igreja baniu a dança do cotidiano das pessoas (FARO, 1986).

\section{Ao final se colocam de frente para rei e rainha}

Em 1975, Pina Bausch coreografou ópera "Orfeu e Eurídice", escrita por Gluck, para sua companhia Tanztheater Wuppertal. Em 2008 a obra foi remontada sob direção e supervisão de Pina Bausch, mas, agora com os bailarinos da companhia "Ballet de l'Opéra National de Paris". Nesta montagem documentada em DVD, o corpo do cantor não é o foco central da cena, assim, os cantores quase não aparecem em cena, que é tomada pela coreografia de Pina Bausch.

O corpo do cantor posto à margem foi tema da palestra proferida pelo pesquisador e professor norte-americano David Levin em 05 de junho de 2012. David Levin é Professor, The University at Chicago (1998), Department of Germanic Studies, the Department of Cinema \& Media Studies, the Committee on Theater and Performance Studies. Ou seja, acadêmico e crítico de arte e literatura germânica. 
Nesta palestra ele cita a ópera "Orfeu e Eurídice" e menciona o fato de que a Pina Bausch tenha "marginalizado" os corpos dos cantores. A questão do corpo posto à margem pode ser considerada uma crítica feroz à imobilidade que tem sido a marca das encenações em ópera. Por outro lado, a opção, ainda que suscite essa crítica pode ter sido a de criar uma linha dramatúrgica particular.

[...] à margem. Av́eu fíqueípensando então, eles estão presentes, estão a margem, e onde está a dissolucão de papeis nessa história? Eu vejo que saio baitarinos, eu vejo a construcão coreográfica, eu não vejo muito esse higar mais hibrido (Vanessa Macedo, 2017, arguicão quatificação).

Embora a obra não seja o DVD, o DVD também é uma obra ${ }^{10}$. Acredito que o Levin provavelmente teve acesso ao

${ }^{10}$ Ficha técnica: PINA BAUSCH: ORFEU E EURYDIKE [DVD E BLU-RAY] Música: Christoph Willibald Gluck (1714-1787). Coreografia e direção de palco: Pina Bausch. Conjuntos, figurinos e design de iluminação: Rolf Borzik. Orpheus: Yann Bridard (dançarina) Maria Riccarda Wesseling (mezzo-soprano) Eurydike: Marie-Agnès Gillot (dançarino) Julia Kleiter (soprano) Amor: Miteki Kudo (dançarina) Sunhae Im (soprano). Ballet de l'Opéra nacional de Paris. Balthasar-Neumann Chor \& Ensemble. Maestro: Thomas Hengelbrock. Informações técnicas: Gravação HD: Opéra de Paris (Palais Garnier) | 02/2008 Direção de TV: Vincent Bataillon Data de lançamento: 18 de novembro de 2009 Distribuição: Naxos Distribuição. 
espetáculo, no entanto, nesta palestra, ele discute para onde a câmera "olha". Os cantores estão à margem da câmera quando se compara com as filmagens de ópera tradicional, em que a câmera filma o rosto do cantor, ou seja, de onde vem o canto/som da voz. No caso de "Orfeu e Eurídice" coreografada por Bausch a câmera busca o corpo dos bailarinos, ou seja, a ação cênica.

A expressão, Ópera Coreográfica, é utilizada pela artista alemã Sasha Waltz (1963). Entwicklung der choreographischen Oper que traduzindo para o português seria o "Desenvolvimento da Ópera Coreográfica", esse conceito implica em um novo tipo de diálogo entre a música, a dança e o teatro em que os artistas (solistas e coro) fazem parte de uma coreografia global, destituindo-se de suas funções previas (MARON at all, 2017). Esse conceito traz à tona a ideia de que não é porque uma ópera tem uma ou mais coreografias incluídas em sua encenação, que ela se torna coreográfica, ao contrário, o contexto processual da produção e a encenação da peça é coreográfica/coreografada por inteiro. A distinção entre coreografia e coreográfica é um ponto importante. Assim, a coreografia não é inerente a ópera, portanto, a ópera coreográfica vem ao encontro de fazer uma ópera coreografada do começo ao fim. Este termo é cunhado e usado por autores como: Sasha Waltz, David 
Levin, Paulo Maron, Trisha Brown, Yinka Shonibare (MARON, 2018).

Minha compreensão de ópera está fundada na prática e sob a ótica de que a ópera é um transgênero que já foi muito bem discutida por Maron (2018).

A ideia de ópera como transgênero, que se realiza num processo transdisciplinar de criação, concepção e ação, fica clara em projetos já realizados, como a ópera Amazônia, descrita pelos seus criadores como um experimento estético-político transcultural.

Percebo que foi a partir do espetáculo "Aniversário e Morte da Rainha Mary II" que nosso trabalho passou a ser completamente transdisciplinar, ou seja, o que passamos a denominar aqui de transópera. Não é um novo gênero ou uma adaptação: é o anúncio do processo como inexoravelmente relacionado ao produto, percurso, conteúdo e forma (não nessa ordem, necessariamente) (MARON, 2018, p.112 e 113).

Logo no exemplo de "Orfeu e Eurídice" de Bausch isso pode não ter acontecido, mas foi um marco para se perceber a necessidade de se ter o corpo como lócus da encenação. Assim como a necessidade de compreender que tipo de formação é necessária para se fazer esse tipo de proposta. No geral isso é algo que sempre esbarra em questões políticas, ou seja, dinheiro, tempo, disponibilidade entre outros. Não acredito que todas as óperas devam ser 
encenadas assim, porém, é desta perspectiva que essa montagem foi concebida.

\section{Parte 2: quando começa a cantar "come" pisar à} frente. No segundo "come" (com sua dupla) como se reverenciando a rainha na ordem estabelecida, vai para trás da fila.

Nesta parte queríamos fazer uma referência aos balés de corte, pois a cena falava justamente de celebrar o aniversário da rainha. Era um convite para reverencia-la. Com isso, construímos as células de deslocamento com os movimentos bem característicos desse tipo de dança, como veremos a seguir.

Para compreender um pouco mais deste universo, trago a Marianna Monteiro, brasileira, graduada em Ciências Sociais e doutorada em Filosofia pela Universidade de São Paulo. Atriz, bailarina, coreógrafa e autora dos livros: Noverre: Cartas sobre a Dança (Edusp,2002), Dança Popular: Espetáculo e Devoção (Terceiro Nome, 2011) e, em coautoria, Antropologia e Performance, ensaios NAPEDRA, sendo o livro "Noverre: Cartas sobre a Dança" o que eu me debrucei para compreender alguns fatos sociais da época. 
O rei da França Luís XIV, (1638-1715) era um grande incentivador da dança e criador da Académie Royale de Musique et Danse. Contudo, não posso deixar de citar Noverre, que iniciou seus estudos na Académie Royale de Musique et Danse, que mais tarde passou a se chamar Ópera Paris. Jean-Georges Noverre foi o principal responsável pela teorização sobre o balé de ação, porém, a paternidade deste gênero não pode ser estabelecida. Observa-se uma tendência geral e difusa do balé a partir de meados do século XVIII, ou seja, não é possível apontar um único criador do gênero (MONTEIRO, 2006).

Em 1672, ano de sua criação, Académie Royale de Musique et Danse tinha por função estabelecer parâmetros para a dança de palco e, ao mesmo tempo, representar a tradição como um guardador de todo o histórico de balé de corte: a opéra-ballet e a comédie-ballet, ou seja, os principais gêneros da época. Esta academia criada por Luís XIV era dirigida por Louis Dupré. O nome opéra-comique foi dado inicialmente aos espetáculos que eram apresentados na feira de St. Laurent, classificados como: pantomimas, acrobacias, arlequinadas, ao estilo italiano (MONTEIRO, 2006).

Voltemos no tempo, um pouco antes do balé de ação, conceitualizado assim por Noverre e compreendamos o que 
foi o balé de corte. Jean-Georges Noverre (1727 - 1810), citoo principalmente, porque a Monteiro traz as suas cartas na íntegra. Ele foi bailarino, professor, coreógrafo, considerado o criador do balé de ação e um precursor dos balés narrativos do século XIX.

O Balé de corte é caracterizado como gênero de dança e está dentro de um todo que é mais amplo, como elemento consistente das festas de corte. Como tal, reunia amadores e profissionais em um espetáculo que era apresentado como uma parte dos divertimentos da corte. Comumente estas festas eram estruturadas por um tema e com um enredo mais ou menos elaborado. A historiografia define o ano de 1581, como ano de nascimento do balé de corte, que tem seu início na França e seria uma arte praticada exclusivamente pela elite da corte. Em sua combinação continham: dança, canto e textos falados e seu objetivo era claramente social e político, um passatempo elegante para toda a corte (MONTEIRO, 2006; FARO, 1986).

As fronteiras entre o balé e o baile nem sempre ficavam claras, pois quando os balés terminavam, esta fronteira era, frequentemente, quebrada, pois os figurantes tiravam as damas para dançar (MONTEIRO, 2006). 
O mais importante é que o balé de corte nasce no momento em que a dança se encontra estreitamente vinculada à vida da corte, que segue rígidas etiquetas. Esses códigos de comportamento ditavam como se deveria dançar, quem poderia dançar e com quem se poderia dançar, por exemplo. Neste momento, a dança era impensável fora do contexto da festa. Aparência, honra e imagem pública eram os valores em voga pela vida da corte, logo, o balé de corte fazia menção a estes temas frequentemente, tanto do ponto de vista da forma como do conteúdo e execução (MONTEIRO, 2006; FARO, 1986).

A festa, na corte francesa do Rei-Sol, onde balé atinge seu apogeu, tanto quanto a etiqueta, serve para classificar e ordenar as relações entre os nobres. $\mathrm{Na}$ festa, deparamos com a ostentação destas "diferenças". A dança, que desde Luciano de Samósata era pensada como imitação do movimento dos astros, garante, agora, harmonia e sentido à movimentação do cortesão e deve necessariamente espelhar sua posição no sistema de poder, ao mesmo tempo se oferece, na forma da alegoria, como metáfora politicamente orientada. O próprio Luís XIV, dançando o Rei-Sol no Ballet de la nuit, oferece, em espetáculo a imagem de seu poder absolute (MONTEIRO, 2006, p.36).

As "diferenças" estão ligadas a hierarquia social e fica evidente o espelhamento entre os lugares e hierarquias que se ocupam na sociedade da época e os espaços ocupados 
durante o balé de corte. Assim, a dança e a etiqueta estão intimamente ligadas, pois, cada pessoa merece seu lugar distinto. Existe uma imagem pública associada ao viver em público. É o que faz da corte um teatro, pois nela tudo está localizado espacialmente e é representado. O balé de corte é uma forma teatral de organizar, em símbolos, as relações sociais. Observa-se, portanto, em três níveis: o das relações de poder, o das relações espaço-temporais e o das relações simbólicas, que são, antes de mais nada, teatrais. Como Ribeiro (1993, p.83) coloca, "A vida pública se reduz à vida em público, a vida que se publica, que se teatraliza" (MONTEIRO, 2006; RIBEIRO, 1993). Neste momento do espetáculo isso é encenado. Essas figuras de poder, etiqueta e hierarquia aparem na coreografia.

\section{Parte 3: Trocas do 1 grupo (Wesley, Isis e Carol); ao final da sequência deles, todos sobem o braço}

\section{juntos.}

Como já foi dito antes, o balé de corte é considerado um gênero e para tal, possui requisitos a serem cumpridos, bem como uma estrutura posta. Assim, o balé de corte é um "conjunto de danças que compõem diversas entrées, entremeadas por recitativos e cantos, seguindo uma organização interna, a partir do desenvolvimento de um tema" 
(MONTEIRO, 2006, p.37). De acordo com o texto de M. de Saint Humbert: "para se fazer um belo balé, seis coisas são necessárias: temas, árias, dança, figurinos, máquinas e organização, [...] para ser belo, tem que ser novo [...]" (HUMBERT apud MONTEIRO, 2006, p.37).

Humbert continua explicando que o tema deve ser bem desenvolvido para que nenhuma das entrées seja irrelevante (MONTEIRO, 2006). Observa-se uma possível preocupação com a dramaturgia. Antes disso, existem requisitos a serem ticados de uma lista, não é simplesmente a dança por ela de qualquer maneira, existe, sim, uma preocupação com um todo que está envolvido, embora, mais tarde se constate que isso seria apenas divertimento proporcionado pelo rei à corte. Fica evidente a relação entre a dança e música.

Veja, o novo também é valorizado. Seja no desenvolvimento do tema, dos figurinos ou das entrée, bem como na combinação desses, de uma forma que ainda não tivesse sido vista. Desse modo, atestam maior capacidade de invenção (MONTEIRO, 2006).

Esse gênero, balé de corte ou ballet de cour, é descrito por Henri Pruières, como "novo que se enfeita com todas as graças e seduções das festas de corte anteriores, emprestando do drama a intriga na sequência e na unidade" 
(PRUIÈRES apud MONTEIRO, 2006, p.38). Ele complementa dizendo que a música e a dança não interrompem mais a ação, mas, pelo contrário participam dela. Cada parte envolvida, "recitativos, árias, balés, pantomimas têm sua razão de ser a partir de um ponto de vista exclusivamente dramático" (PRUIÈRES apud MONTEIRO, 2006, p.38). Parece com a ideia de Richard Wagner (1813 - 1883), que busca na dramaturgia o uso de todos os elementos da ópera, ou seja, uma área vai existir caso a dramaturgia exija que ela exista, como um balé, por exemplo. Assim, a dramaturgia dita o que estará em cena. Assim como aconteceu no "Aniversário e Morte de Queen Mary II".

\section{Trocas do $2^{\circ}$ grupo, ao final da sequência deles todos sobem o braço juntos.}

Observemos algumas outras definições de balé de corte e suas variações:

- Baltazar Beaujoyeulx explica que o Ballet-comique tem por feição o dramático, por objeto os personagens elevados. Ele o chama de cômico pois, do contrário seria tragédia. Como o fim é bem-sucedido e feliz, não provoca nem terror, nem piedade. Ele justifica também dizendo que batizou esse balé com esse nome para primeiro homenagear à dança 
(Ballet) e o segundo para homenagear a história, que é cômica (MONTEIRO, 2006).

- Philippe Beaussant conceitua o balé de corte quando se refere ao prólogo da ópera Dardanus, dizendo que o balé de corte "constituía um todo coerente a partir de personagens alegóricos. Por intermédio da alegoria, inseria danças ao lado de recitativos e cantos, no interior de uma intriga" (Beaussant apud Monteiro, 2006, p.44). É justamente sobre essas alegorias, um pouco mais tarde, que alguns questionamentos são levantados. Por exemplo, não se pinta nem se dança os Ventos com um fole na mão ou um moinho na cabeça; nem o Mundo, como um mapa geográfico; também não caracterizamos a Música com uma roupa toda listrada, carregada de colcheias e semifusas; essas alegorias grosseiras já não pertencem mais ao nosso século (MONTEIRO, 2006). As representações diretas e literais estavam perdendo força.

- Henri Prunières, ao referir-se ao balé de corte, aponta para a diferença em comparação as outras danças existentes até então na corte por sua "intensidade dramática". Prunières explica que as entradas de balé, recitativo, cantos e danças estão na mesma proporção para a ação. Segundo ele, todos esses elementos já eram encontrados em outros eventos da corte como as mascaradas e nos intermédios. 


\section{Nos grupos, quando fizerem juntos, descem o braço no penúltimo "triumphant" do rei.}

A Monteiro (2006, p.39) define em nota de rodapé que: "Intermédios eram formas de representação dançada que se desenvolveram ao longo do renascimento italiano e francês, como parte dos divertimentos e das comemorações cortesãs". Porém, o balé de corte conseguiu um salto qualitativo, pois integra as danças das antigas festas e bailes em um todo dramático com mais estrutura. Ele atribui isso à influência dos ideais humanistas dos franceses da época, que "procuraram reviver o teatro grego" e os coros no drama (MONTEIRO, 2006, p.39).

Pensando nisso retomo a criação da Acadèmie de Poésie et. Musique, em meados do século XVI. Baif, criador da instituição, inspirou-se na movimentação dos coros gregos e trazia também a criação coreográfica para a estrutura da escola; também contribuiu com a Pléiade - grupo de poetas franceses, da segunda geração renascentista francesa, representados pelos poetas Ronsard e Du Bellay procurando restaurar a métrica latina, e se baseava na quantidade de sílabas dos versos. Enquanto isso, Ronsard compunha poemas para serem acompanhados por instrumentos musicais, mais especificamente o alaúde, 
procurando fazer com que a versificação destes poemas (catalogada como a antiga, em breves e longas) fosse a determinante da estrutura na composição musical que as acompanhava, ou seja, a estrutura da composição musical foi alterada. Acredita-se que Baif também tenha procurado os coreógrafos da corte, com o intuito de tentar aprofundar a proposta da academia que era a de estabelecer equivalências entre os três elementos: os passos de dança, a versificação e a música (MONTEIRO, 2006). Observo, novamente, a impressão, de que Baif estava em busca da Gesamtkunstwerk que, traduzindo, seria "obra de arte total" que Wagner descreve mais tarde. Lembrando que, traduzir termos do alemão para o português não é simples, pois os alemães juntam palavras diferentes em uma só e criam uma terceira coisa.

\section{Andam para os lugares (meninas de um lado e meninos do outro).}

A Monteiro (2006) ilumina para que possamos compreender qual era o cerne da academia, que era de "casar" música e dança à poesia, que no caso, era portadora da ação dramática. No balé de corte, existe a preocupação com a unidade dramática, com a constituição de um enredo, tomando como referência o drama antigo. 


\section{Parte 4: avançadas em cânon (cada um no seu}

\section{tempo na ordem) 8 vezes.}

Ménestrier - padre jesuíta e coreógrafo - considera como temas ideais para os balés de corte, a história, a mitologia, a história natural, a invenção poética e o puro capricho. Nessa categoria de histórias, cabem as histórias dos heróis antigos, filhos de um Deus com um mortal, como exemplo: Hércules, Teseu, Orfeu, etc. Ou seja, os temas histórico-mitológicos se fazem presentes no enredo dos balés de corte e se reapropriam dos mais variados temas, buscando reestruturarse dentro de uma unidade dramática (MONTEIRO, 2006).

\section{Parte 5: Pisadas para frente em duplas (plateia)} com o cotovelo para o alto e volta para o fim do grupo - uma vez.

Durante o século XVII - o século em que se desenvolveu o balé de corte - a influência do barroco italiano sobre a França, a Inglaterra e as demais monarquias católicas era vigorosa. Recapitulando, o balé de corte surge no século XVI, vinculado aos ideais humanistas da Pléiade, em meio à renascença francesa. Porém, foi ao longo do século XVII, que o balé de corte se desenvolveu, como parte do processo de incorporação da cultura barroca pelas monarquias católicas europeias. Beaussant (apud Monteiro 2006, p.44) ilumina: 
"diz-se na França com o corpo e com a vestimenta: a moda e a dança são as mais altas expressões do barroco francês...". Se em outros países da Europa o barroco se manifestava através das artes, da poesia, com o movimento de voo do gesto das estátuas, com as curvas e contracurvas da arquitetura, na França, esses setores parecem ter uma resistência (MONTERIO, 2006).

\section{Troca de frente com cotovelo alto (duas trocas).}

Para esta parte do espetáculo, queríamos trazer essa ideia do balé de corte, dos bailes e deixar clara a relação entre corte e cortesãos. Assim, percebo que conseguimos este resultado, pois usamos desenhos coreográficos característicos desse gênero, porém, misturamos com movimentos do cotidiano que exploramos durante o período de preparação corporal.

\section{Ida para o chão.}

Eu lembro bem dos movimentos que fizemos para nos famitiarizar com a "ida até ochão", fazendo com que o movimento de "sentare levantar" fossem realizados da maneira mais orgânica possivel. Esta etapa principalmente me ajudou muito a críar uma relacão mais próxima com mew corpo e com os diversos planos que posso explorar através dele (AndrezzaReis). 
Essa parte do espetáculo termina com todos sentados no chão. Renata e Eu, procuramos explorar todos os planos (alto, médio e baixo). Como a artista Andrezza relata na sua fala.

\section{MÚSICA "SOUND THE TRUMPET"}

Em 2015, quatro anos após Promethée, já muito à vontade em nosso espaço próprio, nós estávamos inquietos por novas experiências. Para nós estava claro que o nosso espaço era onde poderíamos nos arriscar mais. O éthos da ópera tradicional havia sido quebrado. Particularmente eu comecei a me questionar cada vez mais sobre o conceito de ópera. E me perguntei: o conteúdo e a forma podem definir 0 gênero? Se temos uma dramaturgia, cantada e encenada isso pode defini-la como ópera? (MARON, 2018, p.53)

Dueto dos artistas, Paulo Bezulle e do André Estevez, que cantam ao lado do rei e da rainha.

\section{"Sound the trumpet, till around}

You make the list'ning shores rebound.

On the sprightly hautboy play;

All the instruments of joy,

That skilful numbers can employ,

To celebrate the glories of this day." 
Levantar devagar e saltar para ir para lugar da próxima sequência.

Todos terminaram no chão, os meninos começam a levantar lentamente até o acento da música e explodem com um movimento de saltar; meninos se separam das meninas.

\section{Meninas vão depois (no segundo "sound").} As meninas recebem a mesma instrução.

\section{MENINAS e MENINOS em bolinho de frente os dois grupos}

Em lados opostos do palco, meninos e meninas, em dois grupos separados fazem a sequência um de frente para 0 outro.

Executar a sequência em cânon (cabeça 2 vezes lenta e 4 vezes rápidas, perna lenta para direita e esquerda 4 vezes rápidas).
Não tem nenhum único arranjo que de conta de todas as pessoas, assim como, não tem outra forma a não ser sentir $\sigma$ movimento no seu corpo (Marítia velardi).

Esta fala me remete a este momento da montagem, já que o diretor junto com os cantores e coreógrafos, acharam melhor 
que os solistas ficassem junto ao rei e a rainha, pois esse momento do ponto de vista musical, precisava de mais ajustes e já não era mais viável que os solistas dançassem enquanto cantavam. Pois do ponto de vista musical era uma escrita que exigia dos cantores, mais atenção. Decidimos isso juntos. Mais tarde percebeu-se o quanto a cena ganhou por manter os solistas dessa maneira, eles ficaram como os mestres de cerimônia enquanto a corte festejava e o rei e a rainha observavam. Conforme já descrito aqui. Assim, a dramaturgia proposta pelo diretor ganhou mais força. Constatamos que era o que tinha que ser feito.

\section{MÚSICA "STRIKE THE VIOL"}

\section{Parte 1: MENINAS ENCOSTADAS NA PAREDE -}

\section{movimento de balanço de um lado para o outro, bem lento - Renata e Carol avançam.}

Esse processo modificou inchusive as minhas acões como professora e coreógrafa, nas construcóes com as turmas com as quais en trabatho. Modificon a minha ideia de que eu não precisava mais ter a coisa ideatizada, a coreografia pronta na minha cabeca. Percebo agora, inclusive com meus atunos, o quanto isso pode ser construido junto com eles, 
durante oprocesso. Minha construcão vem do baté clássico em que as coreografias ora já saio prontas, no caso dos repertórios, ow ora elas são já definidas previamente, e ew sópasso (ensino) para os atunos. Não existe construir com of alunos. Logo, esta montagem também modificou coisas em mim como professora e coreógrafa (Renata Matsuo).

A coreografa Renta me relata como ela se sente transformada com esta experiência. E assim como a artista Andrezza, Renata também leva para a vida - da sentido e significados próprios - o que experimentou durante o processo de fazer esse espetáculo.

Com a ideia de utilizar todas as possibilidades que o nosso palco permitia, resolvemos usar o fundo do palco e fazer uma célula coreográfica que havíamos experimentado no chão, mas transferimos do chão para a parede e o resultado ficou orgânico, fluido e estético.

\section{Meninos: célula coreográfica nova (macarena).}

Fizemos uma célula coreográfica para os meninos enquanto as meninas estão com uma movimentação diferente na parede, no fundo do palco. Apelidamos de "Macarena", porque assim que a célula termina, o artista começa a fazer 
esta célula novamente, em outra direção, explorando assim, todos os lados do palco (direita, esquerda, frente e traz). Assim como acontece no balé com em croix (em cruz) onde o mesmo passo é explorado em todas as direções: frente, lado e atrás.

\section{Parte 2: SÓ MENINAS - Célula coreográfica que} vai para o chão. Após repetir a célula, reverenciar

\section{a rainha e se colocar no fundo.}

Aqui dividimos as meninas em duplas e/ou trios e elas faziam as células coreográficas.

\section{Parte 3: Angélica e Pedro fazem dueto}

\section{coreográfico.}

Enquanto os artistas Angélica e Pedro, rainha e rei respectivamente, faziam o dueto coreográfico no momento instrumental da música, as meninas estavam paradas no fundo do palco, encostadas na parede de lado, com a perna de trás estendida. Como era comum no balé de corte, a realeza tinha seu momento de dançar, e assim, aqui também o fizemos. Aqui eles começam dançando juntos e depois o rei vai dançar com os meninos e a rainha com as meninas. 


\section{Parte 4: Meninos fazem com Pedro. Meninas fazem duas vezes com Angélica (obs.: tirou 0 braço e perna).}

São células coreográficas diferentes, dos meninos e das meninas. Coreografamos primeiro o dueto (rei e rainha) e, ensaiando este trecho, percebemos que o movimento separado era muito bom também. Optamos por esta célula coreográfica dos meninos e das meninas. Quando a cena acontece, a plateia assiste um dueto e, em seguida, este dueto separado, uma vez que rei e rainha não estão dançando juntos em proximidade, mas estão juntos (ao mesmo tempo) na música e em lugares distantes no palco (lados opostos). Ao final, todos repetem a célula coreográfica mais uma vez. Rei e rainha voltam para o trono e o coro vai para o canto esquerdo. O título deste trecho indica "tirou o braço e perna", mais uma vez percebemos que enxugar a coreografia traria a dramaturgia que o diretor idealizou.

\section{MÚSICA "THE DAY"}

O artista Luiz canta seu solo sozinho, no canto direito, enquanto os reis estão em seus tronos e o coro, do lado oposto ao do Luiz. Todos no canto esquerdo fazem a célula coreográfica da cabeça e cotovelo. 


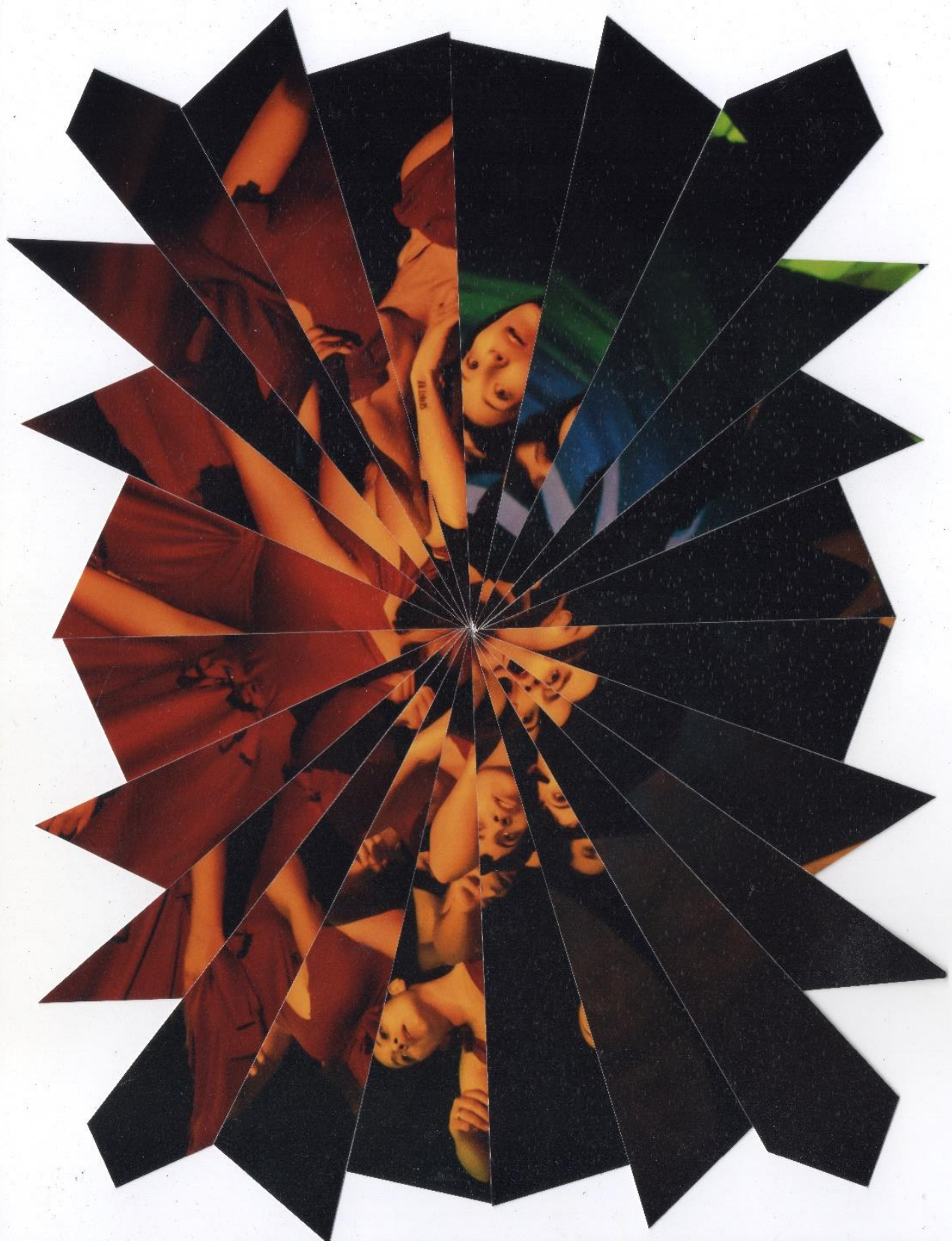

Imagem 11 
Durante o solo do Luiz, a artista Carol começa, em seguida a artista Andrezza, depois o artista Elias, Renata e Wesley. Quando o coro começa a cantar, todos fazem a sequência juntos e terminam olhando para a rainha. No fim da música todos ajoelham, com o joelho direito apoiado no chão.

Outra coisa do ponto de vista do método que eu acho que você precisa fazer: não contar o que o NUO-Ópera Lab. é, mas, sim caracterizar o NUO-Ópera Lab. como campo. Nesse sentido até ouvir o ruri. Pergunte para ele como que se configura um campo? (Marítia Velardi, 2017, arguição quatificação).

Yuri Bassichetto Tambucci é Mestre em Antropologia Social pela Universidade de São Paulo, pesquisador associado do Laboratório do Núcleo de Antropologia Urbana (LabNAUUSP). v Yuri Bassichetto Tambucci é Mestre em Antropologia Social pela Universidade de São Paulo, pesquisador associado do Laboratório do Núcleo de Antropologia Urbana (LabNAU-USP). Atualmente é consultor no projeto Cartografia das Territorialidades Culturais do Campo Limpo, da Escola da Cidade, com atividade iniciada em 2016. Possui experiências em pesquisas etnográficas com enfoques relacionados à Antropologia Urbana, como lazer e práticas de sociabilidade, 
mobilidade, cultura, movimento estudantil e esporte. Artista e violinista no NUO-Ópera Lab. desde 2005.

Campo é uma ideía que a gente está trazendo o tempo todo e que a gente não reflete tanto sobre ela como conceito. Existem outras disciplinas que tratam a ideia de campo como um conceito. A gente usa mais para se referir ao método que se utitiza, uma etnografia por exemplo. A gente fala o tempo todo frases como: "eu vou para campo", "ew vow fazer um campo", "estow em modo campo" (Yuri Bassichetto Tambucci).

Essa ideia me aguça a querer saber mais.

Quando a gente fala de campo a gente está estabelecendo um recorte. $A$ ideia de recorté é importante nesse sentido, porque independente do assunto que a gente vai trabalhar ow o campo, ele nunca é dado, ele nunca se apresenta pra gente, mas ele é construido, elééuma negociação entre pesquisador e o pesquisado (Vuri Bassichetto Tambucci). 
De acordo com a fala do Yuri, o pesquisador chega com as suas próprias questões e as pessoas que ele vai estudar, que vão ser os interlocutores da pesquisa apontam suas próprias questões. A partir do interesse e do objetivo do pesquisador, ele faz um recorte para saber qual vai ser a abordagem que ele vai usar. Então, com essa ideia de uma negociação, não é nem o deles (pesquisados) nem o do pesquisador, mas, é uma coisa que se estabelece a partir dessa relação. Assim, definir um campo é definir um recorte na realidade, e o mais importante, esse recorte deve ser uma negociação. Mas, a ideia de ter interlocutores não me agradava.

Eu não me sentia confortável com essa ideia, pois intuía que haveria mais coisas além do "recorte" e perguntei se teria um outro modo de compreender o que é "fazer campo" e o Yuri explica:

Um outro jeito que a gente usa pra falar de campo já é muito mais uma postura, um jeito de olhar, do que um recorte mesmo. Pra gente é muito comum falar coisas do tipo: "en estow em modo campo" ow então eu não consigo mais fazer una viagem de turismo porque ew sinto que ew "estow fazendo campo o tempo inteiro". Então, a ideia de fazer campo, de estar numa experiéncía de campo, é uma 
ideia de uma postura especifica, de um othar específico que você tem para o que você está vivendo (Yuri Bassichetto Tambucci).

Já me senti mais familiarizado, com mais conforto com essa soma das ideias de postura, jeito de olhar e recorte.

E daí o que acontece nessa situacão é que a gente percebe que "fazer campo", ter essa "postura de campo", não é mais de othar para a diferenca. O conceito que a gente traz que é alteridade. Alteridade de outro, olhar o outro porque o outro é claramente outro, mas, é construir uma alteridade. Construir uma alteridade é você conseguir modular o sew othar. Uma frase que agente usa bastante é "estranhar oque é famitiar e deixar mais famitiar o que é estranho elou exótico" (Yuri Bassichetto Tambucci).

Então percebi que eu construí esta postura frente ao que eu observei/vivi e busquei a postura de criar uma alteridade, criar uma diferença. Então este foi o salto que eu fiz, que é transformar esta alteridade em uma questão epistemológica.

Então fazer campo é você assumir uma postura epistemológica de 
entendimento do mundo que é diferente. Nunca é abandonar você mesmo. Mas, embarcar no que o outro está te propondo. se permitir transitar entre o seu ponto de vista e o ponto de vista do outro. E comisso, as vezes, até criar um novo othar, uma nova lógica, nova teoría (Yurú Bassichetto Tambucci).

Assumo esta postura de me deixar levar.

Quando en comecei a fazer o trabatho NUO-Opera Lab. em 2005, ew tinha acabado de conhecer o pauto e tinha uma pessoa que ia fazer a direça cênica da ópera "Três vinténs" de Brecht, era no Teatro São Pedro. Ali comeceí a trabalhar com a preparacaio corporal, porque tinha uma especificidade que a gente achow que caberia esse trabalho. Naquele momento, comecow a se configurar para mim, porque en estava vivendo em outro tempo académico, que existiam coisas ati que estavamescondidas no cotidiano e que traziam uma certa autonomia no modo de conceber o que, que aquele grupo sería. E aí eu comeceí a intuitivamente tracar alguns problemas de investigacão, tanto que eu fü fazer isso sozinha, nem compartithei com qualquer 
pessoa (Maritia Velardi, 2017, arguição quatificacão).

Nesse momento alguns integrantes do NUO-Ópera Lab. começaram a estudar coisas a partir da experiência que eles tiveram ali dentro do grupo.

- Paulo Maron defendeu Doutorado em Música (2018) Universidade de São Paulo (USP) - título: "NUO-Ópera Lab.: da autoetnografia à trans-ópera";

- André Estevez defendeu o Mestrado em Ciências (2017) - Escola de Artes Ciências e Humanidades (EACHUSP) - título: "O Atleta da Voz: o cantor lírico e o seu corpo";

- Angélica Menezes defendeu o Mestrado em Música (2016) - Universidade Estadual de Campinas (UNICAMP) título: "O canto em cena: investigações sobre o movimento expressivo e a expressividade vocal numa montagem de Dido \& Aeneas, de H. Purcell"

- Wesley Fernandez com a Iniciação Científica (2014) com o título "A ópera que se dança: um estudo sobre Orfeu e Eurídice de Gluck coreografado por Pina Bausch" e o Trabalho de Conclusão do Curso (2015) com o título: "Arts Based Research e o estudo do movimento expressivo" ambas pela Escola de Artes Ciências e Humanidades (EACH-USP). 
Sem contar com os estágios, os artigos científicos e apresentações em congressos científicos que tiveram suas problematizações iniciadas e/ou aplicadas no NUO-Ópera Lab. Então, percebe-se que nesse espaço tem um jeito das coisas fluírem, que outras coisas floresceram e, portanto, iam além daquilo que o grupo se propunha.

A gente vai estudar uma coisa, higar, prática, montagem, quando, nessa perspectiva da qualitativa, na pesquisa de campo - não é exclusividade, não é sempre assim - a coisa sobre a qual a gente vai investigar se constitui como um campo. Eo que é um campo? Vou pegar o Bourdieu só como referência. Não que a gente precise se apoiar nele. Só para se situar. Um campoé um campo quando ele tem autonomia. Dentro de onde? De um campo maior (Maritia Velardi, 2017, arguicão quatificacão).

Então existe o campo que é o da música. A ópera está na música. Então tem um grupo "X”, por exemplo, que está na música e faz ópera. Mas existem outros grupos que também fazem. Por exemplo: a ópera estúdio do Teatro Municipal de São Paulo, ópera estúdio da UNICAMP (Universidade Estadual de Campinas), a ópera estúdio do teatro de Manaus, de Belém, entre outros. Todos fazem ópera. 
Então o que nos aproxima e nos distancia? Quando a gente percebe que o que nos distancia nos mantém ati e cría uma identidade, a gente pode dizer quais coisas nos distanciam. Essas coisas são sólidas? Essas coisas se sustentam? Elas mantêm esse grupo com uma identidade particular? Aqui tem uma coisa que ópera de um modo completamente diferente, que leva este grupo a garantir a suavexistência, sew fortalecimento, sua estruturaça (Maritia Velardi, 2017, arguicão quatificacão).

A Professora segue com seu pensamento:

Então, se todo mundo parar de fazer ópera hoje a gente (NUO-Ópera Lab.) continua? Vamos ter público? Vamos continuar fazendo? (Maritia Velardi, 2017, arguição quatificação)

Interrompo para dizer que sim. Se todos pararem de fazer ópera por qualquer motivo, o NUO-Ópera Lab. continuará a fazer. Pois temos uma estrutura que nos permite autonomia. Estrutura física, que é onde ensaiamos e nos apresentamos; estrutura política, porque não dependemos de nenhum tipo de fomento para existirmos. 
Qual que é a grande crise quando muda a direção do Teatro Municipal de São Paulo? A inseguranca de não se fazer mais ópera em São Paulo. Não ter mais! $O$ teatro São Pedro trocou a gestão. E ficou por muito tempo sem apresentar ópera. Acabow edital, acabou financiamento, acabow. Não existe mais a possibitidade de se produzir esse gênero. $O$ campo é todo regulado por isso tudo. Então isso é o que se configura. $O$ que a gente percebe? (Maritia Velardi, 2017, arguicão quatificação).

A professora mesmo responde:

Que o NUO-ópera Lab. foi sobrevivendo apesar do campo grande. De forma independente, autônoma. Então o Yuri, que estuda antropologia urbana na FFLHC percebe que quando o NUO-Ópera Lab. sai do Teatro Sáo Pedro, porque agora $\sigma$ Teatro São Pedro tinha outros interesses, $e$, essencialmente, porque os artistas do núcleo disseram que não queriam mais ficar ati e perguntam para o pauto: tem como ser em outro higar?

Quando isso acontece o ruri diz assim: se a gente quer fazer as coisas de modo diferente é preciso romper com o éthos da ópera. É preciso romper com o 
palco itatiano, com o modo itatiano, com esse repertorio (Maritia Velardi, 2017, arguicão quatificação).

O repertorio o diretor Paulo já havia rompido fazia um tempo.

A ideia da encenação mais teatral já era um rompimento também. Só faltava o espaço físico. Então esse rompimento é necessário.

Então, algumas diuidas podem ter surgido para algumas pessoas: a gente continua existindo? As pessoas continuaraio vindo fazer parte do grupo? Teremos público? A gente vai sobreviver? A orquestra vai se manter? Os cantores virão para cá? E aí o que aconteceu? Av́é o que o ruri disse: quando o grupo se mantém, ele se configura como um campo (Marítia Velardi, 2017, arguiç̃o quatificaç̃o).

E foi sim para todas as perguntas. Logo, o grupo se manteve e se mantém. E arrumamos outro jeito de sobreviver. E esta é uma decisão que foi tomada e as coisas têm funcionado assim. A manutenção, questão administrativa, quem organiza o que e quem cuida do que. É uma coisa bem diluída no grupo.

Então, é um processo descrítivo, mas do método. Porque aí não estow querendo 
saber o que o NUO-Ópera Lab. é, mas sim o que justifica fazer pesquisa nesse higar? $E$ porque tem tanta autonomia ati dentro em termos de estrutura que te permite ir para atém daquito. E permitem também porque você sabe que aquele hugar vai durar/sobreviver. Talvez você precise fazer experimentos ati e você sabe que pode voltar. Então essa autonomia é fundamental (Maritia Velardi, 2017 arguicão qualificacão).

O NUO-Ópera Laboratório é uma companhia de ópera criada pelo Maestro, Diretor e Encenador Paulo Maron em 2003, que desde então vem produzindo periodicamente duas óperas por ano. Composta por jovens estudantes do canto lírico e artistas que buscam novas experiências artísticas.

O NUO-Ópera Laboratório tem como meta a formação de plateia e, para tal, propõe ao público um repertório diferenciado dos circuitos tradicionais de ópera. Atrelado ao repertório não tradicional, o NUO-Ópera Laboratório busca uma encenação consistente, que valorize a obra e que possa ser compreendida e vivenciada de forma completa, ou seja, música, texto e encenação.

A cada nova montagem a companhia se propõe a investigar um autor que embase a prática a ser realizada e investigada. 
Como resultado, a produção de uma nova obra. O tempo de preparação para cada montagem é muito valorizado e importante para a companhia. A ideia é buscar autores como: Stanislavski, Grotowski e Meyerhold. A encenação que NUOÓpera Laboratório busca está apoiada por estes pensadores e fazedores do teatro. As técnicas de dança moderna como: Martha Graham, Laban, Cunningham entre outros, e a dança étnica, como por exemplo, flamenco, odissi, kathak, butoh e etc. A Educação Somática como a inspiração no Método Feldenkrais são ferramentas para alcançar o resultado proposto pelo diretor do grupo.

O NUO-Ópera Laboratório realizou mais de 20 montagens, ao longo de mais de dez anos de trabalho contínuo, sempre com grande público. A presença de um novo público não habituado ao gênero é atualmente o espectador das montagens.

No meio acadêmico, o NUO-Ópera Laboratório tem sido reconhecido e considerado como espaço de estágios e de investigação artística e acadêmico-científica. 


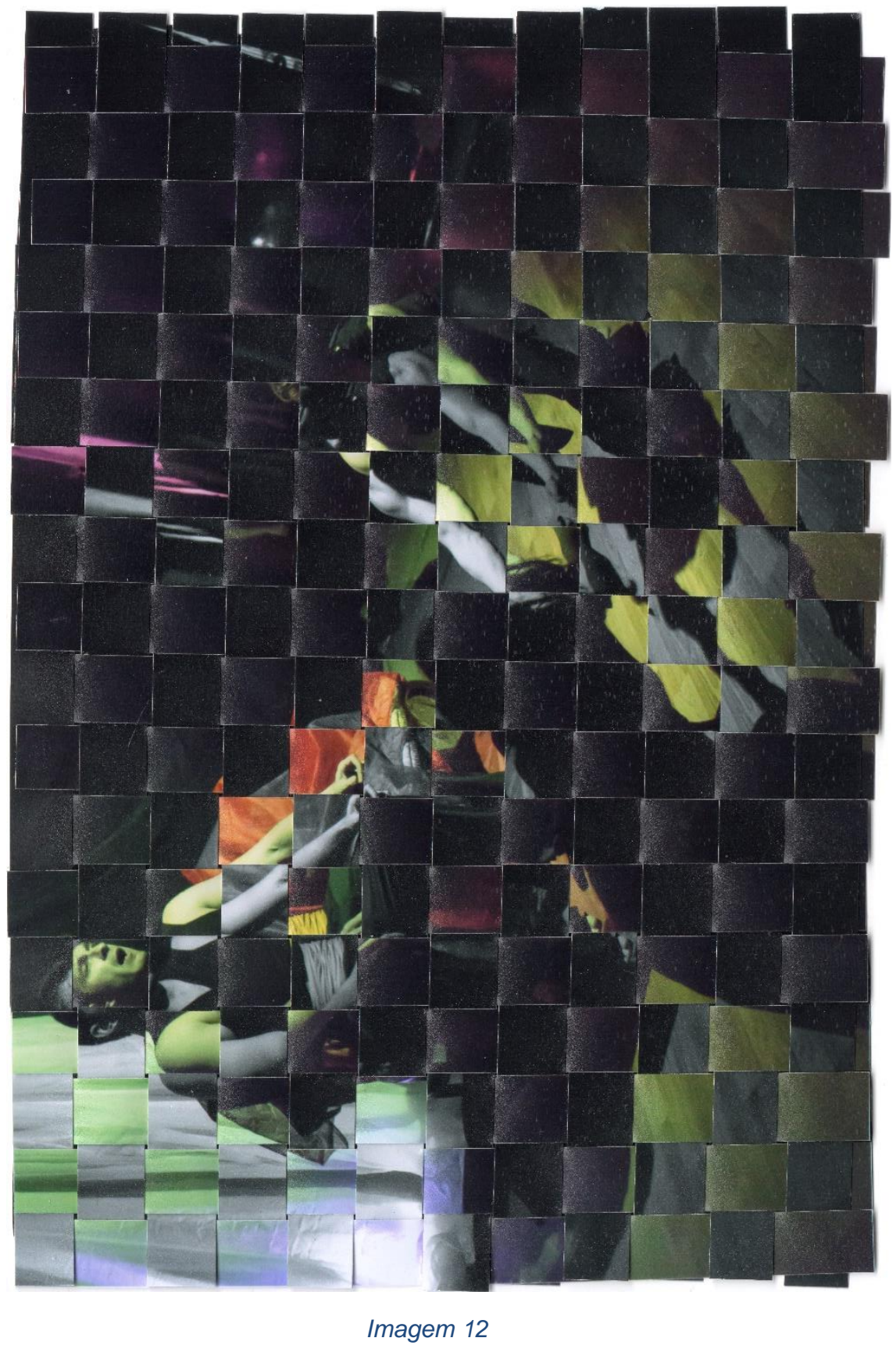




\section{MÚSICA "BID THE VIRTUOS"}

Todos permanecem abaixados, somente as artistas: Andreza e a Isis, que revezaram o solo cantado, estão em uma postura mais alta. O dueto dançado pelos artistas/coreógrafos Renata e Wesley.

Então a gente vem pra universidadel Academia porque o que tem aqui permite responder algumas questöes. Isso não quer dizer que o que a gente faz aqui é superior ao senso comum, ou é superior ao que o artista faz, as questöes que eles colocam, ou a pesquisa do artista ou à pesquisa do artesão. É outra coisa. É que ati a gente não responde ao que se pergunta. Então a gente vai num hugar, universidade, onde encontra formas de responder, ou de problematizar e ou de ampliar. Então o discurso que nós fazemos, que pode ser ou textualperformático, tem que ser um discurso acadêmico. Então fazemos uma escrita performática, mas ela é acadêmica. E oque isso quer dizer? É uma escrita que mostra que o conhecimento que fazemos na universidade é distinto daquele conhecimento que se podería produzir sozinho num outro higar. Caso contrárío, não faz sentido. Fundamental 


\section{dizer que não é hierarquizado. (Maritia}

Velardi, 2017, arguicaio quatíficação).

O trabalho de descrever o "Aniversário e Morte de Queen Mary II" é um desafio e foi escrito por todos que participaram desse processo de algum jeito. Minha tarefa foi desvendar COMO ou QUAL seria a melhor maneira de trazer esse processo para a vida e torná-lo processo sempre, para que esse trabalho escrito seja vivo.

Os cadernos de campo-pedagógicos, e digo no plural pois existe o meu pessoal e o da Renata Matsuo, que foi minha parceira neste projeto, refletem principalmente o processo, que foi trazer para o palco "Aniversário e Morte de Queen Mary II". As anotações foram diluídas ao longo do trabalho escrito, porém, percebo que existe algo que eu ainda não trouxe, que foram as rotinas, as coisas cotidianas, anotações feitas como:

São Paulo, 31/03/2015

$\checkmark$ Lição Feldenkrais

$\checkmark$ Exercícios dos pés (frente, lado, traz, lado)

$\checkmark$ Movimentos circulares (punho, antebraço, braço)

$\checkmark$ Movimentos circulares (punho, antebraço, braço) somado ao deslocamento

$\checkmark$ Partitura corporal 1 e 2 
São Paulo, 07/04/2015

\section{$\checkmark$ Lição Feldenkrais \\ $\checkmark$ Exercícios Martha Graham - chão, banco, em pé \\ $\checkmark$ Partitura corporal 1, 2 e 3}

Somados a estes exemplos, anotei também algumas reflexões, coisas que eu ouvia do elenco, diretor, preparadora corporal e coisas que eu falava e ao me ouvir falar, corria para anotar.

Quando estudávamos as células coreográficas eu disse: "Perceba a alternância de tensão e apoios". E percebi que a minha maneira de pensar/ensinar estava em sentir o movimento, alterar a dinâmica e variar a qualidade do movimento. Verifiquei também que fui criando ferramentas de exploração para as partituras. E foi assim, explorando cada partitura criada com as múltiplas possibilidades, que as coreografias foram nascendo.

Então, pegar um elenco pronto, maduro e mais velho foi uma experiência nova, uma experiência impar e incrivel; e também, ao longo do processo, eu fui perdendo o receio e me encantando (Renata Matsuo). 
O espetáculo como um todo foi acontecendo assim. Ou seja, o diretor Paulo Maron nos dava alguns pontos específicos, seja na música, seja como por exemplo, da pintura do Caravaggio, e a partir desses pontos, que chamei de esqueleto, fomos recheando com as coreografias. Primeiro o esqueleto, em seguida, vamos recheando com movimentos, coreografias, os espaços existentes. E a questão da formação aparece novamente, porque, a coreógrafa Renata aponta para um elenco disponível. Acreditamos que a formação do artista é ad aeternum, ou seja, o artista está sempre em constante aprendizado. Portanto, 0 artista/cantor/ator/bailarino segue crescendo de modo solitário buscando o que ele acredita ser bom; e/ou dentro dos coletivos, onde existem as relações de confiança e colaboração. E quando ela diz "mais velho", ela está comparando com os alunos dela que tem entre sete e treze anos.

A partir disso, mais um turning point, percebi que existem vários caminhos para executar uma mesma ação, movimento, coreografia, entre outros. Além disso, ficou evidente para mim que a movimentação orgânica era mais fácil de ser aprendida pelos integrantes, mas exploramos outras possibilidades também, que nem sempre eram confortáveis e, por isso, a qualidade estética ficava comprometida. Questionei-me 
várias vezes sobre qual é o movimento certo? Qual era o errado? Ao longo do processo entendi que depende sempre do objetivo final, porém, o errado para mim, depois de passar por essa experiência, é o movimento que causa algum tipo de dor/lesão.

Os movimentos para as partituras corporais e, mais tarde, coreografias, foram sempre inspirados nas lições do Feldenkrais que, por sua vez, tem inspiração na movimentação cotidiana. 


\section{MÚSICA “THESE ARE THE SACRED”}

These are the sacred charms that shield

Her daring hero in the field;

Thus she supports his righteous cause,

Thus to aid his immortal pow'r she draws
Estes são os encantos sagrados que protegem

Seu audaz heroi no campo; Assim ela apoia a causa justa dele,

Assim a assistir seus poderes imortais ela se coloca (tradução nossa).

\section{Todos permanecem abaixados}

O teto não tem acabamento, o piso também não; cortinas de tecido separam os ambientes, o palco é feito com placas de mdf. Duas varas de luz carregam refletores caseiros, as cadeiras são longarinas usadas, compradas de uma igreja evangélica que fechou. Setenta e oito lugares organizados em praticáveis de madeira que sobrou da construção, a madeira que foi usada para sustentar a laje de concreto até que ela secasse. Um espaço rústico, feito sob medida. Essa rusticidade era o que nós buscávamos. No dia da inauguração eu pensei que essa falta de acabamento na construção pudesse ser constrangedora, mas as pessoas foram unânimes em dizer que esse era 0 charme do espaço e, mais do que isso, a sua identidade. Um dos jornalistas que foi conhecer 0 nosso espaço queria fotografá-lo e nós ficamos preocupados: não tire foto daqui, dali, vire a câmera para lá - orientamos, na nossa tentativa de escondermos as falhas no acabamento. Foi quando o fotógrafo nos falou que era aquilo que interessava: aquilo era uma marca e um marco (MARON, 2018, p.74). 
Não tem melhor maneira, no meu ponto de vista, do que esta descrição do "Espaço Núcleo". É assim, cru, direto, um espaço a ser preenchido com as presenças, com experiências e possibilidades que antes não haviam sido tentadas. Como diz na música, são nossos "encantos sagrados".

Este é o solo cantado/dançado pelo artista Luiz e dançado pela artista Carol. Ao final desta música, meninos se deslocam para o canto direito.

\section{MÚSICA “SEE NATURE” MUDANÇA.}

Criada no período barroco na Itália, a ópera carregou consigo a ideia de aproximação entre a música e a cena. No entanto, em meados do século XVII, a performance vocal se sobrepôs à cena, à dramaturgia e à própria música. A linha melódica das óperas passou a ser escrita para enfatizar a performance vocal e os compositores tentaram, então, modificar de algum modo essa realidade, buscando romper a supremacia do bel canto. Como resultado, pensou-se em enfatizar a criação de cenários grandiosos, trazendo outros atrativos para o público, além da voz dos cantores. Identificando que isso não trouxe a mudança esperada e contrário ao tradicional modelo da ópera italiana, o compositor Christoph Gluck (1714-1787), conduziu um processo de modificação considerado a primeira grande reforma da ópera ao concluir que o maior problema da ópera 
não era visual, mas musical. O compositor eliminou o excesso de coloraturas na melodia, fazendo com que não fosse mais necessário que o cantor se apresentasse quase como um atleta da voz. Até meados do século XIX essa concepção posta por Gluck influenciou os compositores de ópera. No entanto, a necessidade de ampliar a complexidade na escrita musical trouxe a volta da supremacia do bel canto, especialmente em Rossini (HAREWOOD, 1997).

\section{Parte 1: Enquanto cantam, Andreza e Luiz,} dançam a coreografia. Coro permanece atrás deles, parados

Problematizar a ópera. Não precisa esgotar a históría da ópera, nem da danca. Porque o teu campo não te leva a pensar isso. Teucampote leva a pensar: que bagunca é essa e o que se faz, é subversão? (Maritia velardi, 2017, arguicão quatificação)

O alemão Carl Maria Von Weber (1786 - 1826) trouxe, na primeira metade do século XIX, ao mesmo tempo em que a ópera italiana reverenciava o compositor Gioachino Rossini (1792 - 1868), outro ponto de reflexão: a temática deveria ser modificada para que a ópera não sucumbisse novamente ao virtuosismo do canto, de modo que o todo dramático - o 
enredo, o libreto - pudesse ser valorizado, e não apenas o canto e a voz dos cantores (MARON, 2013). A grande mudança, no entanto, ocorreu anos mais tarde, na segunda metade do século XIX, quando o compositor alemão Richard Wagner (1813 - 1883) instaurou um novo modo de concepção da ópera que anunciou um modelo no qual a dramaturgia e a encenação não se sobrepõem nem se subordinam à forma musical. Antes de Wagner, a ópera era pré-estruturada em relação ao uso das árias, duetos e coros. Com Wagner a forma musical segue a estrutura do texto dramático, o que significa, por exemplo, que se o texto possibilita/pede a inclusão de uma ária, isso é feito, do contrário, ela não precisa estar presente apenas por se tratar de uma ópera. Ao longo deste trabalho escrito percebo o quanto as transgressões dos artistas me inspiram a transgredir como artista e acadêmico.

\section{Na última parte da música os dois fazem um dueto juntos.}

Podemos concluir que as grandes modificações propostas por Gluck, Weber e Wagner seguiram a ideia de mudanças musical (Gluck), temática e de enredo (Weber) e, por fim, na forma (Wagner) (BOURNE, 2008). 


\section{Parte 2: Quando entra o coro, os dois grupos}

\section{fazem as células com eles.}

Essas mudanças atingiram mais do que o universo musical e influenciaram decisivamente a encenação e o teatro daqueles tempos, bem como o teatro e a encenação contemporâneos.

Apesar de todo o percurso de modificação da ópera, parece ainda haver uma ditadura do canto sobre a dramaturgia, a cena e a encenação. As montagens tradicionais da ópera, bem como as montagens dos repertórios clássicos, são ainda mais evidentes do que novas visões que, em geral, não são vistas com bons olhos, como tem sido estudado por Velardi (2011). O desenvolvimento de estudos que aprofundem o potencial de adaptação e de encenação na ópera poderão auxiliar no desenvolvimento do pensamento crítico sobre o assunto, especialmente junto aos jovens artistas em formação.

\section{No último pedaço da música, Pedro sai e meninos o seguem e meninas deslocam rapidamente para o outro lado do placo, por trás do trono.}

Este é o único momento que algum artista sai de cena. Isso aconteceu porque a dramaturgia que o diretor deste espetáculo queria pedia que isso acontecesse. $O$ rei vai para 
a guerra. E por estarmos todos em cena o tempo todo, lembro de uma fala da preparadora corporal do grupo:

\section{o pesoé a essência do ser humano na} terra, conecta com o presente (Marítia vetardi).

O artista da cena, seja ator, cantor, dançarino ou qualquer outro, tem uma missão essencial que é a de estar no presente. Por experiência e conversando com os integrantes do NUO-Ópera Lab. e outros colegas de cena, a ansiedade de "lembrar o que vem depois" daquilo que se está fazendo pode tirar este estado corporal de presença. Por isso, esta lição de sentir os pés apoiados no chão nos conecta com o que está acontecendo naquele momento e não com a possível insegurança do que virá. 


\section{MÚSICA “SINFONIA" INSTRUMENTAL}

\section{Paulo Maron}

29 de maio de 2015

Oi Pessoal, faltam 15 dias para nossa estreia. Vendo as fotos, mesmo sem ter visto o ensaio de ontem, dá para ver o quanto vcs estão envolvidos e prever o resultado desse espetáculo. Mais uma vez vcs acreditaram nas minhas ideias e materializaram o que eu tinha na minha cabeça. Faltam arestas para aparar, inclusive musicais, mas tenho certeza que os ensaios gerais serão verdadeiras récitas. Até terça, estudem a música, curtam as fotos e NUO FOREVER!!

\section{吗 Curtir}

\section{PARTE 1: Meninos vão lentamente pelo chão, receber "benção" da rainha.}

Esse é um trecho instrumental, ou seja, ninguém canta e a cena acontece a partir da movimentação dos corpos, da ação cênica que aqui é dançada, assim como nas músicas cantadas.

"No NUO-Ópera Lab. partimos do princípio de que qualquer dramaturgia que se una à música em um 
espaço cênico é ópera. Pois, se pensarmos de maneira inversa, concebendo que qualquer obra musical que se una a uma dramaturgia e ocupe um espaço cênico é teatro, a recíproca deve ser a mesma. Mas é basicamente um tipo de afirmação centrada na ideia do que não é ópera que sustenta esses comentários. $O$ que a ópera não é. O que a ópera não é? O que não é ópera?" (MARON, 2018, p.95)

Este é o conceito que acredito/acreditamos para este trabalho escrito e para o meu/nosso fazer artístico. Durante o exame de qualificação a Profa. Dra. Marília Velardi me orienta no seguinte sentido:

Ao mesmo tempo, agente vê as pessoas explorando o gênero (ópera), e a importancia que o Wagner teve para o teatro universal é absurda! Todos of encenadores importantes do teatro moderno falam da ópera, encenaram ópera, se preocuparam com a ópera. Acham a ópera uma experiencia incrivel para o ator! O próprio Stanistasski dizia: o tempo dilatado da emocão declarada na fala da ópera é uma coisa que precisa de uma interpretação elow de uma ação cénica que todo ator deveria experimentar. $O$ ator/cantor dizer/cantar "eu te amo", ou seja, uma única frase que na música tem seu tempo dilatado para por exemplo, 15 segundos, é muito 
diferente de dizer "eute amo" como se fala no cotidiano. Essa extensão da emocão que a palavra e a música promovem, exige do ator um trabalho corporal-porque ai não é gênese do personagem, é físico - um trabatho fisico em termos de expressãolassociacão da voz cantada, da musica e do corpo do ator, que todo ator deveria experimentar (Maritia Velardi, 2017 , arguiç̃o quatificação).

Maron (2018) explica e discute o conceito de ópera em sua tese: "NUO Ópera-Lab.: da autoetnografia à trans-ópera", no caderno: "Pensando Ópera". Essa leitura (tese) somada a esta constatação da Professora reforçam a ideia de que a ópera é um gênero à margem da música e do teatro. Ou seja, a ópera é marginalizada.

Podería substituir-se o canto, se a pessoa não souber cantar, pela fala, e aquela duracão permitiría a extensão da emoção. Como é eu dizer "eu te amo" por 10 segundos? Que corpo é esse que precisa dizer "eute amo" por 10 segundos? A ópera, ela é colocada como um apêndice, mas, a importáncia dela na configuracão do próprio teatro moderno e contemporâneo, é crucial. Tanto que as pessoas estão subvertendo, porque tem potencial ati 
(Maritia Velardi, 2017, arguição quatificacão).

$E$ foi isso que eu tive a oportunidade de viver, a cena e a palavra dilatada pela música e o corpo encenando a coreografia. Patrice Pavis (1947) francês, estudioso do teatro, escreve sobre a ópera "Les Coréens" (Os Coreanos) encenado na Coreia, em seu livro "A encenação contemporânea origens, tendências, perspectivas". No trecho que segue:

"O ator-dançarino, ajudado pela coreógrafa e em conformidade com o desenho geral da encenação, constrói pouco a pouco um comportamento uma atitude, uma tensão característica de seu personagem, isso resulta de uma técnica corporal que é, ao mesmo tempo, individual e, em parte, comum aos personagens do mesmo grupo, essa técnica solidifica-se numa tensão corporal do corpo em pose: do mais leve (WenTa) ao mais rígido (Kim) " (PAVIS, 2007, p. 73).

As palavras de Pavis me ajudam a compreender o que fizemos nesta ópera coreográfica.

\section{PARTE 2: Meninas e meninos vão receber benção, intercalando.}




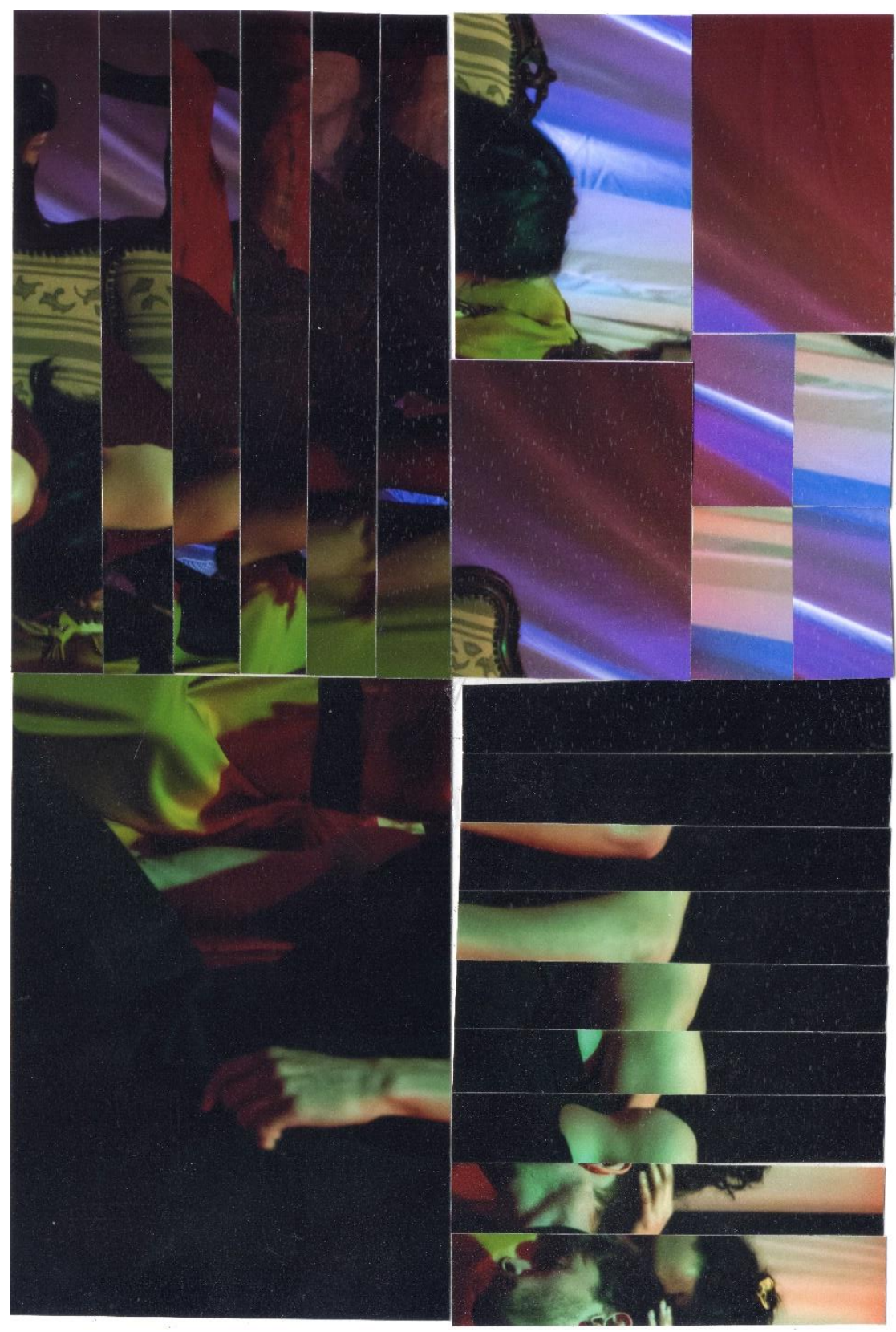

Imagem 14 


\section{PARTE 3: em grupo se deslocam no 12 e no 6.}

Aqui "12 e 6", são a referência da preparação corporal inspirada nas lições de Feldenkrais e que já foi explicado anteriormente. Ao final desse deslocamento (ainda nesta música), Renata, Eliane, Wesley e Elias pegam o tecido e cobrem a rainha. Todos ficam de costas para a rainha.

\section{Cena VI - SOLO DA RAINHA, CANÇÃO DA NOITE.}

Do seu leito de morte, o trono, a artista Angélica, canta com o manto negro sobre si.

\section{Cena V - EPIDEMIA DE VARÍOLA. MUDANÇA}




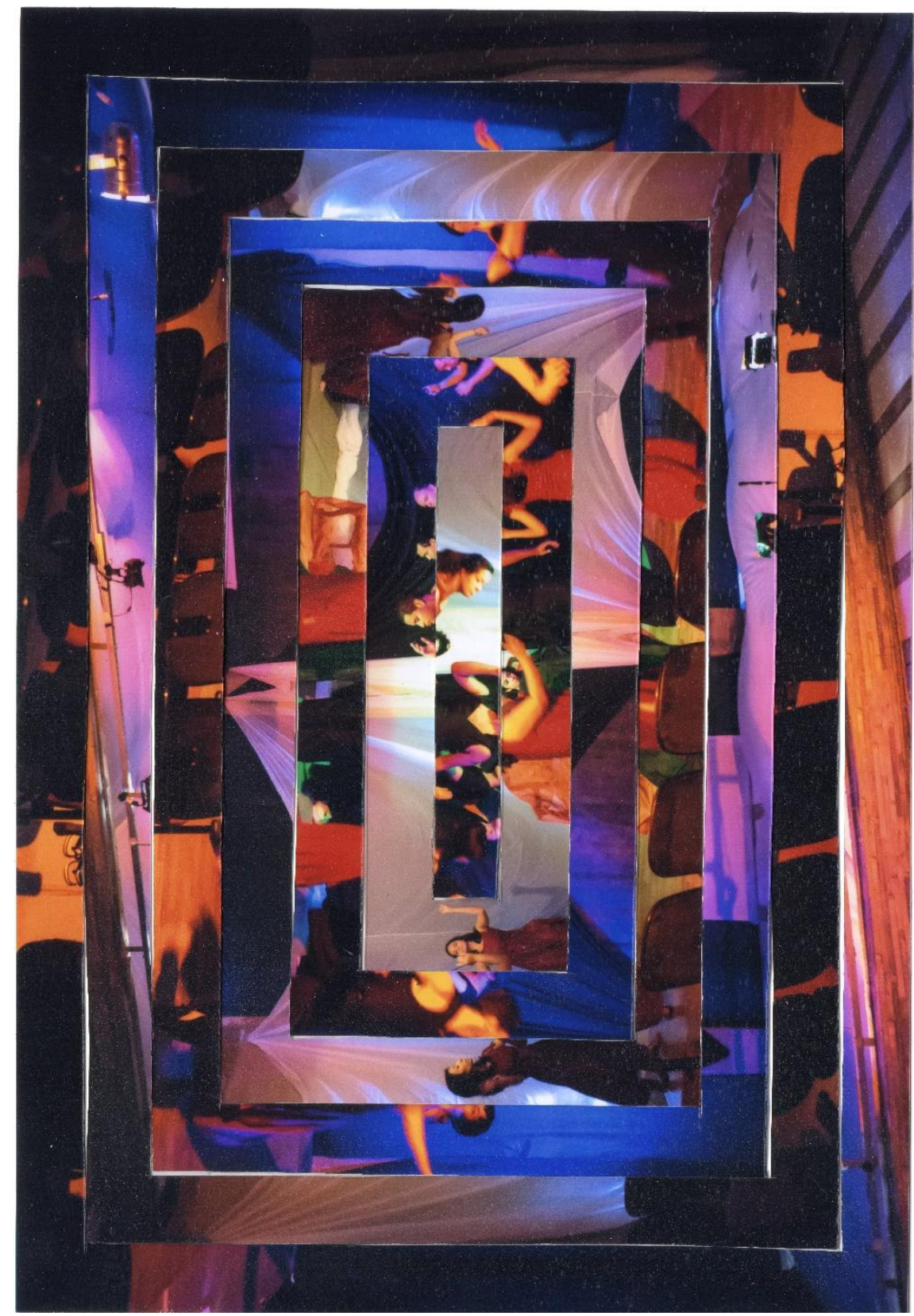

Imagem 15 


\section{Começa a chacone - dança da corte - desconstruindo.}

Aqui resgatamos a ideia de balé de corte, porém, descontruindo, como se a epidemia estivesse se alastrando. Quando pegamos essa célula coreográfica e estudamos mais a fundo, percebi que uma estrutura simples de movimentos e fora do contexto tem uma riqueza grande de detalhes e sutilezas. E nos debruçamos a descobrir essas possibilidades para levar isso para a cena. Sentindo a música através dos movimentos, com isso percebemos como a música fica coerente para a movimentação. Percebi, vendo e fazendo, o quanto a música mobiliza para realizar os movimentos e o que ela deixa mobilizar para que isso aconteça.

\section{Sete partes}

Tomo consciência de como este trabalho como um todo não tinha movimentos narrativos da cena, não era literal. Nenhum movimento era mimético. Sempre poético. Percebi mais claramente isso quando estudávamos as células sem música, ou com outra música. Sem a luz, o cenário, o figurino, a música, a cena anterior e a posterior, aquilo era uma cena que poderia facilmente se encaixar em outros espetáculos, mas, dentro do contexto, ela ganha a força e a expressividade que 
o diretor pediu para o coreógrafo. Por isso não vejo outra maneira de escrever este trabalho. Busco essa poética...

\section{Parte I - 24 compassos}

\section{Duetos: André e Renata, Luís e Andrezza, Wesley e Isis - o último sente sintomas da doença.}

A dança encarada como drama. Uma ruptura é sinalizada, para isso se exige da dança uma outra dramaticidade, neste momento os tempos haviam mudado. Nesta dramaticidade nova, espera-se que o herói não seja tão passivo, que exista mais tensão e ação e que exista menos intervenções sobrenaturais e uso de alegorias. A partir da virada do século (XVII para XVIII), a novidade se dá na maneira de encarar os recursos expressivos da dança, quando os balés deixam de ter vínculo com as festas e bailes, o que provoca uma mudança radical nas condições de produção e fruição da dança. A dança, então, passa a ser vista como drama, mas a concepção dramática do espetáculo de dança, muda. Noverre, em suas cartas, aponta que por trás da repetição de velhos princípios, aparece uma forma radicalmente nova de encarar o balé (MONTEIRO, 2006). 


\section{Parte II - $\mathbf{3 0}$ compassos}

\section{Eles vão para o lado... Retorna André e Renata e}

também sentem sintomas; saem. Voltam Luís e

\section{Andrezza e sentem sintomas... Os 3 casais e sentem sintomas.}

Seria este ponto, um ponto de ruptura, logo, a emancipação da dança?

Se no balé de corte, a ação era inseparável, ou seja, a ação faz parte de maneira indissociável da essência do divertissement, para Noverre ação é oposta ao divertissement. Assim, para Noverre esta era a primeira particularidade do conceito do balé de ação. Para ele, o divertissement, é como elemento estranho ao drama, não tem função no desenvolver da sequência das cenas. $O$ divertissement, então, é uma dança que se "assemelha aos fogos de artifício, que se limitam a agradar os olhos, uma forma vazia, desprovida de qualquer caráter de expressão" (MONTEIRO, 2006 p,46), ou seja, é apenas um divertimento monótono, logo não fala à alma. De acordo com Noverre, esses balés que se contentam com esse efeito menor divertissement - são assim por carência dos artistas. Ele acrescenta: divertimentos são "tediosos, mortos e 
inanimados" e procuram apenas agradar os sentidos. (MONTEIRO, 2006 p.46; NOVERRE, 1952).

\section{Parte III - 16 compassos}

Divide em dois grupos mistos, um de cada lado dançam de frente ... Solo grupo I, solo grupo II "contact improvisation".

"Divertissement quis primeiro dizer o desviar-se da monotonia e da falta de sentido da vida terrena, mas, no caso do balé de corte, fazia-o constituindo uma coerência alegórica, reforçando ideais religiosos e monárquicos" (MONTEIRO, 2006, p.48).

A dança desenvolveu-se na corte como divertimento, em meio à caça e à esgrima, em resposta às ansiedades típicas da forma de pensar barroca (contrastes mais fortes, maior dramaticidade, exuberância, realismo e uma tendência ao decorativo). Neste momento existe a mudança do significado social da dança, portanto, as transformações no contexto da criação e da fruição da arte em geral e dos balés, em particular. Agora há uma desqualificação do divertissement de danse. Observamos uma mudança radical na forma como esta arte - dança - passa a ser produzida, pois, ela abandona a corte e o universo de festa. Com isso, ocorrem mudanças e transformações quando a dança se transfere para os teatros 
da cidade, passando a atuar com outro público (MONTEIRO, 2006).

\section{Parte IV (cellos) - 24 compassos}

\section{Todos começam a sentir os sintomas, um de cada da dupla.}

O contexto social e a insatisfação de ter a dança como algo apenas para ocupar o tempo é uma inquietação também política de Noverre, uma vez que o divertimento serve somente para distrair do cotidiano e a arte, talvez, provoque um senso crítico. Isso seria viável dentro da corte? Será que o balé saiu deste espaço cortesão para buscar maior liberdade?

[...] em tempos de Luís XIV, toda vida intelectual estava ainda sob a proteção do rei e não havia apoio fora dele e muito menos contra ele; mas, agora, surgem novos protetores, novos patronos e novos centros de cultura; a arte, em grande parte, e a literatura em sua totalidade, vão passar a desenvolverse longe da corte do rei. Os membros da nobreza, espalhados em seus castelos e palácios, se divertem nos teatros, nos bailes e nos salões da cidade... A "cidade" já não se limita a existir junto a corte, mas quer assumir sua própria função cultural (HAUSER apud MONTEIRO, 2006, p.48). 
As críticas aos divertimentos trazem consigo a necessidade de ocupar um novo espaço. Espaço esse, que tem relação com o público pagante, diversificado e anônimo, uma vez que na corte conhecia-se bem a "plateia". Novas condições de produção artística surgem e são criadas a partir do início do século XVIII (MONTEIRO, 2006).

A mudança de contexto reflete-se no questionamento de quais formas dramáticas devem, de direito, existir na sociedade parisiense, tendo em vista a nova geografia do que é público e do que é privado que começa a se forjar no início do século XVIII e que implica uma mudança de distribuição das formas espetaculares em vigência, e a aparição de novos gêneros dramáticos.

O processo que fala Hauser, como momento de dissolução da arte cortesã, ocorre simultaneamente à multiplicação dos balés nos teatros públicos e os bailarinos e bailarinas começam a ser tratados como profissionais. A concentração de produção artística e intelectual desloca-se para os salões e o centro cultural. Lembrando que a concentração de produção artística e intelectual era detida pela corte. A França, por exemplo, desloca esse centro de Versalhes para Paris. Com isso, abre para um público cada vez mais amplo e diversificado (MONTEIRO, 2006). 
Aqui percebo um marco importante na história do NUO-Ópera Lab., quando conquistamos nosso espaço próprio. Com isso, uma maior diversidade de público, pois já não era mais uma plateia conhecida, assim como o texto diz, logo a cima. Nossa geografia, Rua Belas Artes, 135, Ipiranga, São Paulo - SP.

\section{Parte V - 24 compassos}

\section{Um do grupo da esquerda desfalece, eles 0} seguram e "tratam dele"; o mesmo acontece com o grupo II.

A diminuição da influência da corte sobre a produção artística e a diversidade dos centros criadores de dança, eram os dois principais apontadores da descentralização citada anteriormente. Com o surgimento de novos focos de produção dos balés na Europa, fora França e Itália, ampliamse os centros de influência, que passam a incluir a Inglaterra, a Áustria, a Alemanha e a Rússia. A partir deste ponto, começa a história das danças teatrais (MONTEIRO, 2006). Acredito que dentro do NUO-Ópera Lab., não ter um fomento nos garante essa "diminuição da influência da corte", nos dá a liberdade para experimentarmos os processos e investigações artísticas que quisermos. 


\section{Parte VI - 21 compassos}

\section{Cada grupo se divide em dois para "tratar", eles começam a melhorar.}

A mudança agora se localiza no tipo de dependência do profissional em relação à corte. $\mathrm{O}$ artista passou a depender cada vez menos do dinheiro dos reis e rainhas, podendo começar a pensar em viver em função do público, pois qualquer pessoa, seja príncipe, princesa ou nobre, pode manter sua companhia de balé, além da liberdade de ocupar novos espaços com a abertura de teatros. Isso se deve também à Revolução Francesa. Com isso, o balé se internacionaliza e as bailarinas(os) conseguem permissões cada vez mais longas para atuar nos teatros da Europa (MONTEIRO, 2006). Os artistas do NUO-Ópera Lab. também não dependem das verbas de fomento, temos outras ocupações, em geral, professores apaixonados por pedagogia, mas, no meu caso, agora estou a trabalhar como auxiliar de cabeleireiro. Sem compromissos financeiros, mas com ganhos de outra natureza. Isso me/nos garante liberdade artística.

Os mestres franceses são detentores da supremacia de tudo que diz respeito ao balé, porém, falar da história do balé de ação e não levar em consideração a experiência e 
contribuição dos ingleses, que entrelaçadas de forma original com as tradições francesa e italiana, tanto da Commedia dell'Arte quanto do balé de corte, seria um demérito. As contribuições deles conduzem a dança para um lugar diferente do que estava acontecendo até então, uma nova perspectiva, uma nova realidade. Tudo isso ocorreu ainda no início do século XVIII (MONTEIRO, 2006).

Uma nova busca é delineada: a dança precisa tornar-se expressiva. Era possível encontrar expressividade na relação entre bailarinos e nobres dentro dos âmbitos das festas da corte, no baile e/ou nos espetáculos de balé, porém, os códigos não são mais capazes de serem compreendidos pela plateia, que neste momento é plural, ou seja, a expressividade que era conhecida pela corte não é fruída pela plateia heterogênea. Logo, uma nova expressão pública começa a ser gerida (MONTEIRO, 2006).

Acrescido a este fato, vale lembrar que no século XVII, os membros da corte participavam dos próprios espetáculos e dos balés, assim, não existia diferença alguma entre dança artística e a dança da sociedade, ou seja, o dançarino profissional executava os mesmos passos que o amador. No balé de corte, artistas e espectadores não tinham distinção. Profissionais e nobres estavam participando da mesma cena. 
Misturados, confundiam-se em tais espetáculos. Por exemplo, no libreto do Ballet-comique de la reine, ao grand bal toda audiência dança para finalizar o espetáculo. O grand ballet, momento final de muitos balés de corte, nada mais é que incorporação, no espetáculo, do baile.

O balé de corte nunca foi o que chamamos de espetáculo; constituía uma espécie de espelho ideal; a natureza dos atores não era em nada diferente da dos espectadores; o rei, seus fidalgos e suas damas brincavam de apresentar a imagem mais bela de si mesmos diante de seus pares. O balé de corte não passava de uma codificação do baile, acrescida de imaginário.

Embora com uma estrutura dramática mais elaborada, o balé de corte ainda era um divertissement para nobres, feito por nobres, que cumpria, como arte eminentemente cortesã, uma função social especifica (BEAUSSANT apud MONTEIRO, 2006, p.53).

Nesses balés, fica evidente a necessidade de ostentação, o que nos leva a compreender que a sua função principal era o entretenimento, pois os nobres recebiam como parte da sua educação, algum treinamento de balé e a partir disso, expunham-se como bailarinos. Assim, a dança ainda não se diferencia da festa como um domínio particular da expressão pública. Noverre critica o divertissement e recusa-se a dar o título de "balé" ao balé de corte. Para ele, "são como sombras incompletas" (NOVERRE, 1952, p.240). Ele justifica dizendo 
que "não diz nada e não tem transcendência alguma sobre as outras artes que concorrem igualmente para os encantos, a elegância e a maravilha de tais representações" (NOVERRE, 1952, p.241). Ele continua explicando que os divertimentos só apresentam "a beleza mecânica da arte, que com um título apenas a enfeitar-Ihe nada oferecem de inteligível" (NOVERRE, 1952, p.241). Noverre os compara com a pintura, "lembra aqueles retratos feitos pelos primeiros pintores, embaixo dos quadros foram obrigados a escrever o nome dos personagens que queria retratar e da ação que deveriam representar, de tanta que era imperfeita a imitação, fraca a expressão do sentimento" (NOVERRE, 1952, p.241). Ele se incomoda com o fato dos divertimentos levarem o título de balé, pois, para ele, não bastava que fossem "espetáculos suntuosos" (NOVERRE, 1952, p.240).

[...] festas resplandecentes que reúnem ao mesmo tempo, a magnificência da cenografia, as maravilhas dos maquinismos, a riqueza do vestuário, a pompa dos trajes, os encantos da poesia, da música e da declamação, a sedução das vozes, o brilho do artifício e da iluminação, os atrativos da dança e do balé (NOVERRE, 1952, p.240-241). 


\section{Parte VII - 16 compassos}

\section{Todos se recompões numa apoteose da corte.}

Noverre surpreende-se que a pintura e a escultura tivessem alcançado graus de excelência, que a música, um pouco mais tarde, também alcançasse, enquanto a dança continuava sem vida, sem caráter, sem ação. Assim, a dança continuava presa às práticas de civilidade (MONTEIRO, 2006).

No século XVII existe a sinalização de um gênero chamado opéra-ballet. Este gênero foi criado por André Campra, depois da morte de Lully. Na opéra-ballet, a dança se une aos recitativos, às arias e aos coros, contudo, diferentemente da ópera, ela ocupa aqui o primeiro plano. Parece que o gênero deixou de ser usado depois de 1770 (MONTEIRO, 2006).

$\mathrm{Na}$ primeira metade do século XVIII, aconteceram muitas inovações no campo da prática artística. Isso porque, além de Noverre, outros bailarinos e mestres do balé procuravam por novos recursos expressivos para a dança. Começa-se a conceber a dança a partir de recursos expressivos, até então ausentes na tradição do balé. Buscava-se, por exemplo, a expressividade dos mímicos para que uma mensagem fosse transmitida sem que fosse preciso o uso da palavra, ou seja, um movimento descritivo (MONTEIRO, 2006). 
Com isso, a ideia de unir a dança à linguagem dos gestos, aumenta. Em 1717, com a apresentação do espetáculo intitulado "Os amores de Marte e Vênus", foram descritas como "danças pantomímicas que se alternavam com as danças de conjunto, definindo um amálgama entre dança e pantomima, o que dava um toque de novidade à obra" (MONTEIRO, 2006 p.60). Este foi o caminho encontrado, até então, para trazer a expressividade desejada.

Ao que parece, nesse ponto, o que distinguia a dança da sociedade da dança teatral era a pantomima já que a plateia era capaz de compreender "perfeitamente o intérprete através de seus movimentos, embora ele não dissesse nenhuma palavra" (MONTEIRO, 2006 p.62). Noverre estava em busca de responder sua inquietação quanto a existência de uma "dança mecânica" e uma "dança de expressão". Na tentativa de unir essas duas possibilidades, Noverre encontra uma possível resposta: a de somar dança com pantomima. Pantomima, segundo ele, deveria emocionar a partir da história, sem se utilizar de código algum, o que contrapõe os princípios de Meyerhold, que anos mais tarde nos apresenta uma movimentação antinatural.

Suas críticas são diretas quando ele fala sobre o rumo que a dança está seguindo, sobre a mera execução de passos 
versus a dança cênica. Noverre observa que a técnica e/ou o virtuosismo dos movimentos talvez sejam um empecilho para acessar essa dança expressiva.

Essa combinação de passos numerosos bem ou mal encadeados, esse desempenho difícil, esses movimentos complicados despojam, por assim dizer, a dança de palavras. Mais simplicidade, mais doçura, maior suavidade nos movimentos dariam ao bailarino mais facilidade de retratar e exprimir-se; poderia dividirse entre o mecanismo dos passos e os movimentos próprios à expressão das paixões. A dança livre das pequenas coisas poderia então dedicar-se às grandes. Tudo indica que a estafa resultante de um trabalho tão penoso abafa a linguagem do sentimento (NOVERRE, 1952, p.305).

Estes trechos iluminam como é importante uma justaposição entre técnica e expressão e como seria o equilíbrio entre elas para realizar um espetáculo digno de ser chamado de "balé" por Noverre. E como é coerente a fala dos artistas que participaram da montagem em estudo no que diz respeito à organicidade do movimento e de como mover-se, e no caso, dançar foi algo que era necessário para encenar/expressar esta ópera.

Desde o final do século XVII, eram apresentados números de danças variados, como uma espécie de pot-pourri de danças nas noites de gala da Ópera e/ou nos espetáculos com função beneficente para algum artista. Aconteciam os típicos 
divertissement de dança nos moldes da Acadèmie Royale de Musique et Danse (MONTEIRO, 2006).

A inovação se dá em 1720 com o balé intitulado "Os Caracteres da Dança" composto por Françoise Prévost (16801741), a partir da obra de Jean Ferry Rebel (1666-1747). Tal balé coloca o foco na sequência que ocorria de forma simultânea entre música e dança, assim, apresentam a dança associada a um tema, pois, a simples sequências de dança não bastavam, era esperado que cada dança significasse alguma coisa (MONTEIRO, 2006).

"Na revisão do paradigma entre música e dança há incorporação de parte da experiência passada da música e da dança francesa e introdução de um terceiro elemento: a pantomima" (MONTEIRO, 2006 p.69). Esta afirmação reforça as ideias propostas até então.

Noverre elucida com a ópera, como ele compreende as relações entre a dança e a música, dizendo que "a música está para a dança como as palavras estão para a música. [...] a dança em ação é o órgão que deve dar conta e explicar claramente as ideias escritas da música" (NOVERRE, 1952 p.252). A ideia é que a música é uma espécie de texto e que a dança deve interpretar. Penso em duas coisas: 1) entendendo a música como uma investigação acadêmica, a 
dança seria a performance desses dados, como sugere Denzin (2017). 2) logo, dessa ligação que ele faz da dança com a música, somada com o conceito de dança associada ao tema musical, levam-me a recordar as teorias dos afetos.

\section{Eles percebem que a rainha está morta... Terminam todos em torno dela.}

Essa teoria diz que um determinado modo musical poderia influenciar os homens das mais variadas maneiras, ou seja, alterar/criar/transmitir o estado de espirito/ânimo do ouvinte. Então, o pensamento daquela época (período barroco), era que a música e o seu sentido musical deveriam ajudar no entendimento do conteúdo contextual, ou seja, adequar a música ao sentido das palavras, com o intuito de expressar a potência de cada emoção diferente para tornar o texto vivo. Por exemplo: para expressar alegria, utilizar intervalos longos e para a tristeza, intervalos pequenos. Porém, não houve um consenso em relação às tonalidades bem como, a influência nos afetos, o que torna esse modo de concepção dos afetos na música, um conceito que tende para uma interpretação pessoal (GATTI, 1997; MELO, 2011).

Autores como: Meyerhold (1874 - 1940), Dalcroze (1865 1950), Stanislavsky (1863 - 1938), Mnouchkine (1939), por exemplo, reconheceram o potencial afetivo e cognitivo das 
manifestações musicais e nos indicaram possíveis caminhos para pensar o trabalho criativo do ator aos olhos das afecções musicais. Portanto, uma vez que o corpo pode ser instruído a partir das qualidades de afecção, a música pode ser o caminho que nos ajuda a conhecer, a encontrar os afetos. Se o trabalho do ator é essa aprendizagem de ser afetado, a música pode ser um agente facilitador (GOMES, 2014).

A ópera francesa conseguiu assimilar o balé de corte e a tragédia clássica graças ao Jean-Baptiste Lully (renomado compositor de balés). A ópera francesa evoluiu em conjunto com os ideais do balé de corte. Observa-se que a ópera francesa dava uma importância à palavra no recitativo, ou seja, insistiam na primazia da palavra sobre o canto (MONTEIRO, 2006).

A ópera na França era diferenciada, por exemplo da ópera na Itália. Assim, quando se fala em dança na ópera, os Italianos e seus partidários eram favoráveis a exclusão do balé, pois, consideravam um elemento heterogêneo no espetáculo lírico. Por outro lado, aqueles que gostavam da ópera francesa, somados a Noverre, acreditavam que o balé era um verdadeiro elemento da ópera. A crítica sobre a ópera francesa, era principalmente daqueles que defendiam um ideal de verdade e naturalismo. 


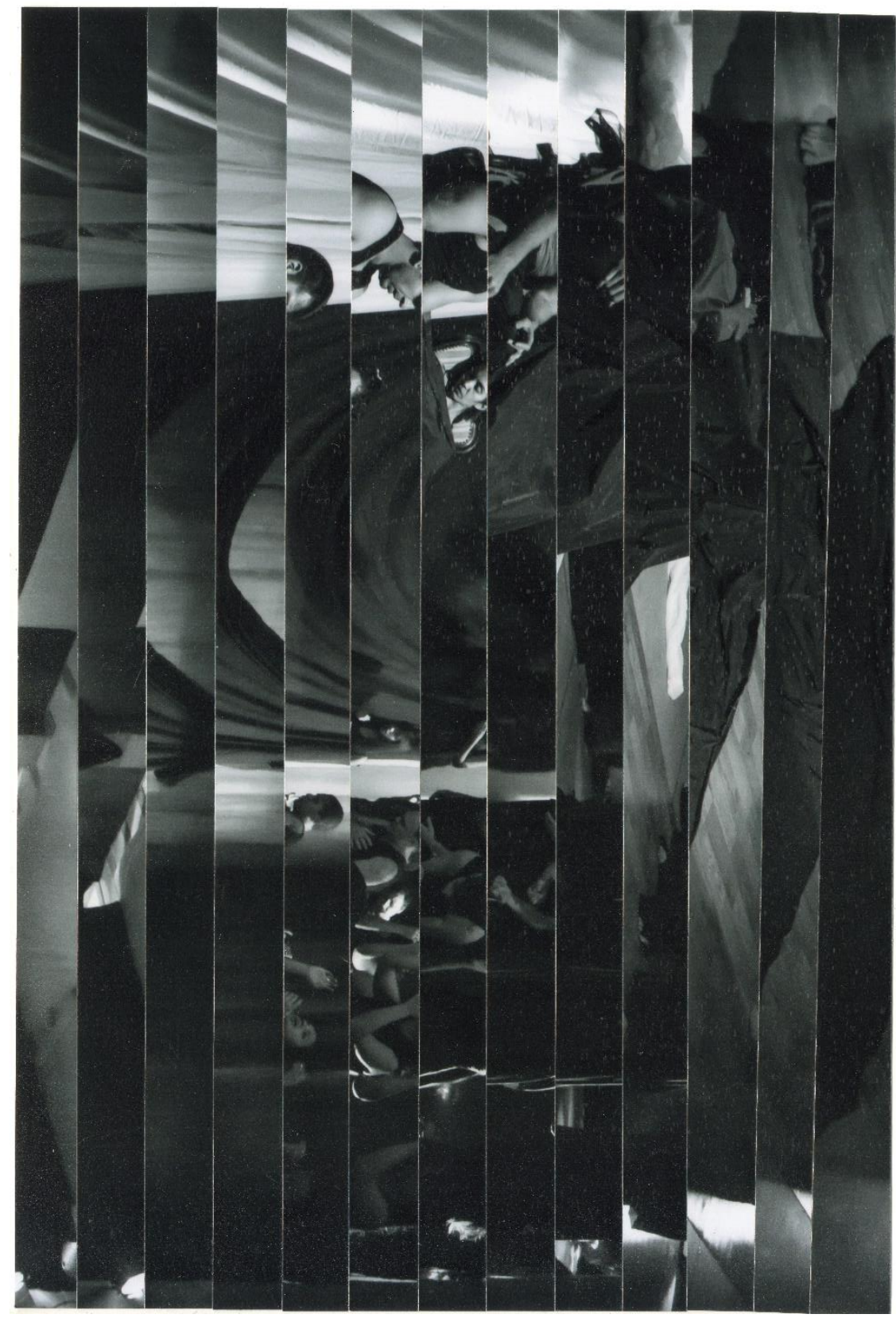

Imagem 16 


\section{Fim de chacone - todos olhando para a rainha.}

Observamos como a Monteiro (2006) sintetiza:

Os recursos tradicionais da ópera francesa - os temas maravilhosos e mitológicos, os prodígios cenográficos, a larga utilização da maquinaria de teatro e, principalmente, os balés -, tudo visa à expressão. É por isso que os partidários da ópera francesa são também favoráveis à manutenção do balé como parte integrante da cena lírica.

Já para os partidários da música italiana, toda beleza da obra de arte estaria em conformidade com a capacidade que tem de evocar sentimentos; o aparato por demais complexo da ópera francesa atrapalha a expressão espontânea dos sentimentos humanos. Acusando o teatro lírico francês de antinatural, inverossímil e dramaticamente incoerente[...] (MONTEIRO, 2006, p.86-87).

Lully é um dos criadores do espaço do balé na estrutura da forma musical da ópera. Provavelmente, por incentivo do Rei Luiz XIV, veio a inserção dos primeiros balés na ópera; com o passar do tempo esse fato vira tradição para a ópera francesa. Assim, o balé era considerado elemento de adorno na estrutura da ópera. Diretor/Maestro Paulo Maron (2018) nos ajuda a compreender a estrutura da ópera: 
No século XIX o ballet era incluído nas óperas em seu segundo ou terceiro atos, em pontos culminantes da ação dramatúrgica. Os trechos instrumentais entre as cenas eram previstos na escritura das partituras, ou seja, faziam parte da forma musical e era praticamente impensável uma ópera (como forma) composta sem a inclusão de um ballet emoldurando as narrativas musicais (MARON, 2018, p.146)

\section{Entra o Rei - coro se coloca na frente dele, tentando impedi-lo.}

O Rei, interpretado por Pedro, retorna da guerra e tenta ver sua rainha. No entanto, um a um, o coro se coloca na sua frente, tentando impedi-lo de ver que sua rainha não vive mais.

Noverre inquietava-se com o divertissement e para ele isso era um problema para a dança. Observo que está uma questão também do teatro, como fala o Anatol Rosenfeld no texto "Problemas do Teatro". Ele explica dos problemas que escapam o espaço cênico, o de atuação do ator.

A indústria de diversão é, hoje, em todos os níveis (qualquer que seja o regime), um sistema que, ao produzir suas mercadorias em série, produz ao mesmo tempo, igualmente em série, o consumidor para essa mercadoria. Longe de satisfazer necessidades de conteúdo qualificado (a não ser o desejo geral e vago da distração), a indústria, ao criar 
os produtos, cria paralelamente a necessidade de adquiri-los. (ROSENFELD, 2017, p.81)

\title{
Enfim, ele vê a rainha morta, inspira forte e se ajoelha, e começa a cantar "hush".
}

\author{
Hush, no more, be silent all, \\ Sweet Repose has clos'd her Eyes. \\ Soft as feather'd Snow does fall! \\ Softly, softly, steal from hence.
}

No noise disturb her sleeping sence.

\section{Na entrada do coro ele se prostra diante dela de costas para o público. Nunca senta ao trono.}

\begin{abstract}
A ópera coreográfica "Aniversário e Morte de Queen Mary II" e esta investigação aconteceram da maneira que aconteceram, por conta dos participantes e das relações estabelecidas. Assim, as reflexões que consegui fazer aqui foram por conta destes autores:
\end{abstract}




\section{Aniversário e Morte da}

Rainha Mary II

\section{direçăo}

Paulo Maron

Oficina de Preparaçäo coporal

Para Arte Cênica

Marilia Velardi

\section{Coreografias}

Renata Matsuo

Wesley Fernandex

Personagens e intérpretes

Pedro Ometto - Rei Willian D'Orange Angélica Menezes - Rainha Mary II

Participaçäo de Luis Fidelis Carolina Maran Andre Estevez Paulo Bezulle Andrezza Reis Isis Cunha

Camenesta Noe Carimete- Pedro Hesautto Trompo- Evereson Germas. Vieri Tumbermed Comatrabaices Silvie Silven Pinasede Mrende

\section{NUO}

Opera Laboratório

apresenta

Aniversário e Morte da

Rainha Mary II

Música de Henry Purcell

Concepção Paulo Maron

Dias 20,21,27 e 28

de junho 2015

Sábados 20h30

Domingos 18h00

no

Espaço Núcleo

Rua Belas Artes 135 (Metrô Alto do Ipiranga)
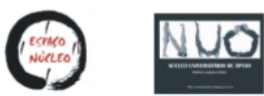

Imagem 17 - Programa distribuído nas apresentações

Este foi o programa distribuído durante as apresentações. Foram 4 apresentações previstas e uma apresentação extra devido à procura do público. 


\section{O coro forma um agrupamento em torno do trono e faz movimentos de lamento enquanto canta.}

http://www.guiadoator.com.br/nuo-faz-sess-o-extra-de-aniver...

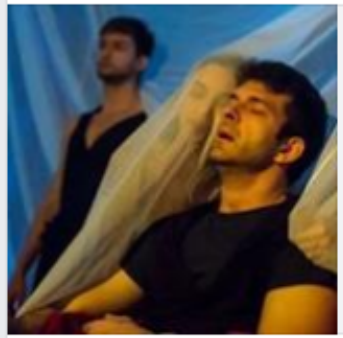

GUIADOATOR.COM.BR

NUO faz sessão extra de Aniversário e Morte da Rainha Mary II

O NUO (Núcleo Universitário de Ópera) encerra a temporada de Aniversário e Morte da Rainha Mary II, neste domingo, dia 21 de junho. Além das.

Angélica Menezes, Ana Carolina Maran e André Almeida Rocha

Visualizado por 25

d) Curtir

Comentar 


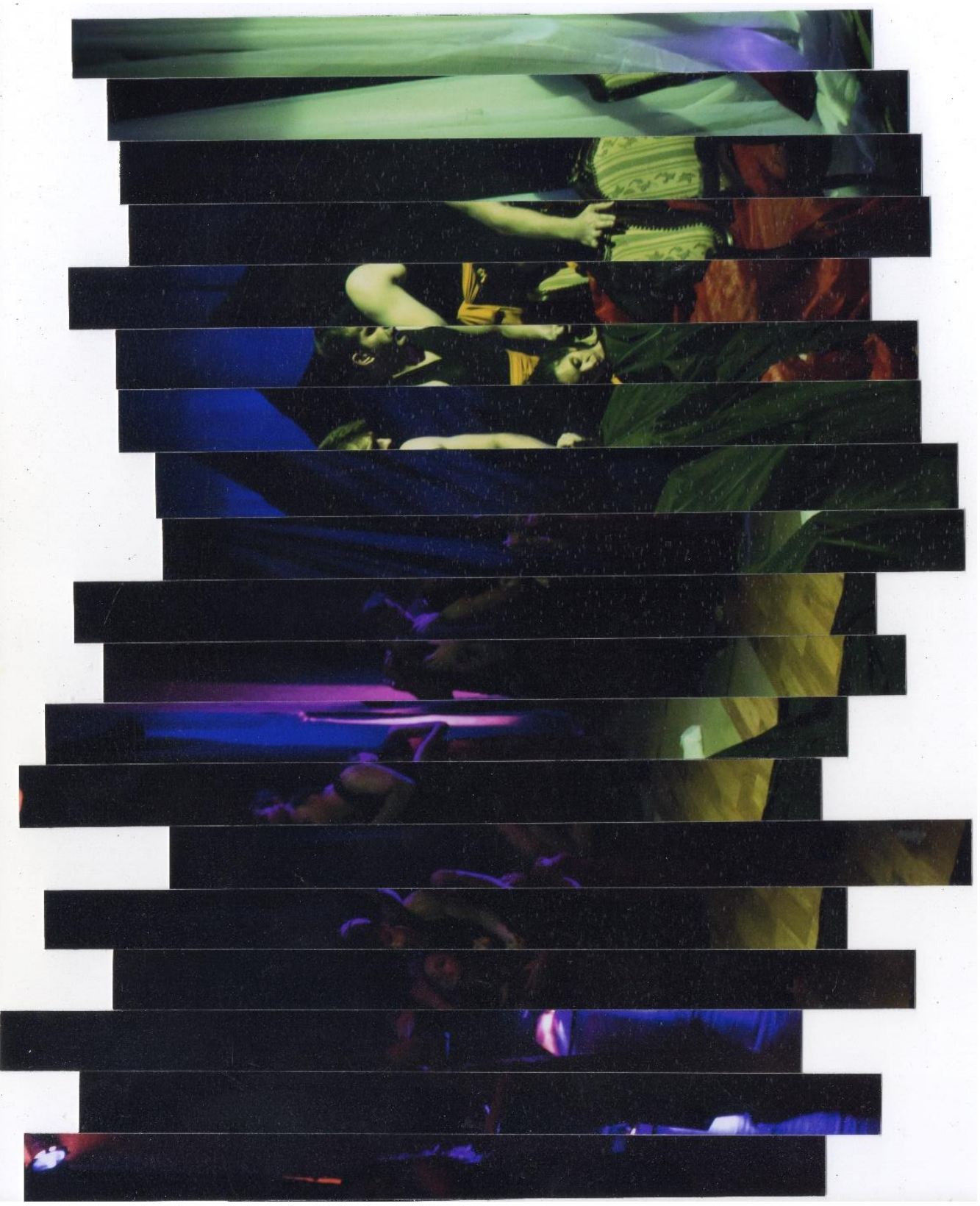

Imagem 19 


\section{Ao tocar os tambores, o Rei tira o manto que cobre a rainha.}

Ao longo do processo escrito deste trabalho tive o cuidado de aproximar autores, não só por suas ideias e pensamentos, mas, também pela linha do tempo ou como o Tim Ingold propõem dos emaranhados de fios vitais, ou seja, que tiveram de alguma maneira algum tipo de relação, seja por parceria ou por linhagem de estudos. Seguindo essa lógica, fiquei inquieto com o contexto alemão já que muitos dos autores que cito neste trabalho nasceram ou passaram por lá. Sendo assim cheguei até Anatol Rosenfeld, que explica em seu livro "Teatro Alemão I parte esboço histórico" (1968) os traços fundamentais do expressionismo.

Como o simbolismo, o expressionismo é um movimento de tendência idealista (no sentido filosófico), dirigido contra o positivismo e as concepções naturalistas, decorrentes do cientificismo da segunda metade do século XIX (ROSENFELD, 1968, p.96).

Rosenfeld segue explicando que era recomendado aos pintores, por exemplo, que não pintassem diante dos objetos, copiando-os, mas, que os reproduzissem baseados na memória desse objeto. Ele acreditava que "num processo natural de seleção, costuma salientar a ideia essencial e pôr de lado e "esquecer" os detalhes acidentais, chegando assim 
a uma imagem simplificada e estilizada" (ROSENFELD, 1968, p.96).

Enquanto Rosenfeld me ajuda a compreender como era o contexto e os conceitos do Teatro Alemão, compreendo também como foi fazer essa produção artística, como foi fazer as fotos que eu recortei e como foi fazer esse texto que você lê agora. Ele sintetiza esses processos que tive a oportunidade de estar presente. Ele continua iluminando meu caminho e explica que esse movimento tende a uma forte subjetivação na medida em que "valorizam ao extremo as operações da imaginação (baseados na memória), cujas imagens refletiram uma realidade mais profunda que a empírica da nossa experiência corriqueira" Rosenfeld, 1968, p.97).

Os expressionistas radicalizam o procedimento, projetando, de vez, as suas intuições e visões intimas, sem mediação de impressões exteriores. Passam a manipular livremente os elementos da realidade, às vezes fortemente distorcidos, conforme as necessidades expressivas de uma imaginação que opera sob forte pressão emocional (ROSENFELD, 1968, p.97).

Mais uma vez, e não foi isso que eu/nós fiz(emos)? Com as fotos que eu "manipulei livremente", com o método que me 
propus a trazer e com o processo e resultado da ópera coreográfica aqui retratada/performada.

A encenação expressionista acompanha uma dramaturgia que, na expressão de Rice, quer apresentar radiografias do ser humano e da situação social. Ora, a radiografia não apresenta semelhança exterior com o seu objeto, mas, revela a estrutura interna dele como nenhuma fotografia poderia fazê-lo (ROSENFELD, 1968, p.119).

Com isso, acredito que a pesquisa aqui realizada (texto) e a pesquisa artística (ópera coreográfica) se aproximam para além de eu conseguir separa-las, ou seja, estão em justa posição. Uma só existe por conta da outra e a outra tomou outro folego para uma nova vida.

\section{A música do funeral começa... Somente na repetição forte a rainha é erguida. 0 cortejo começa e todos saem.}




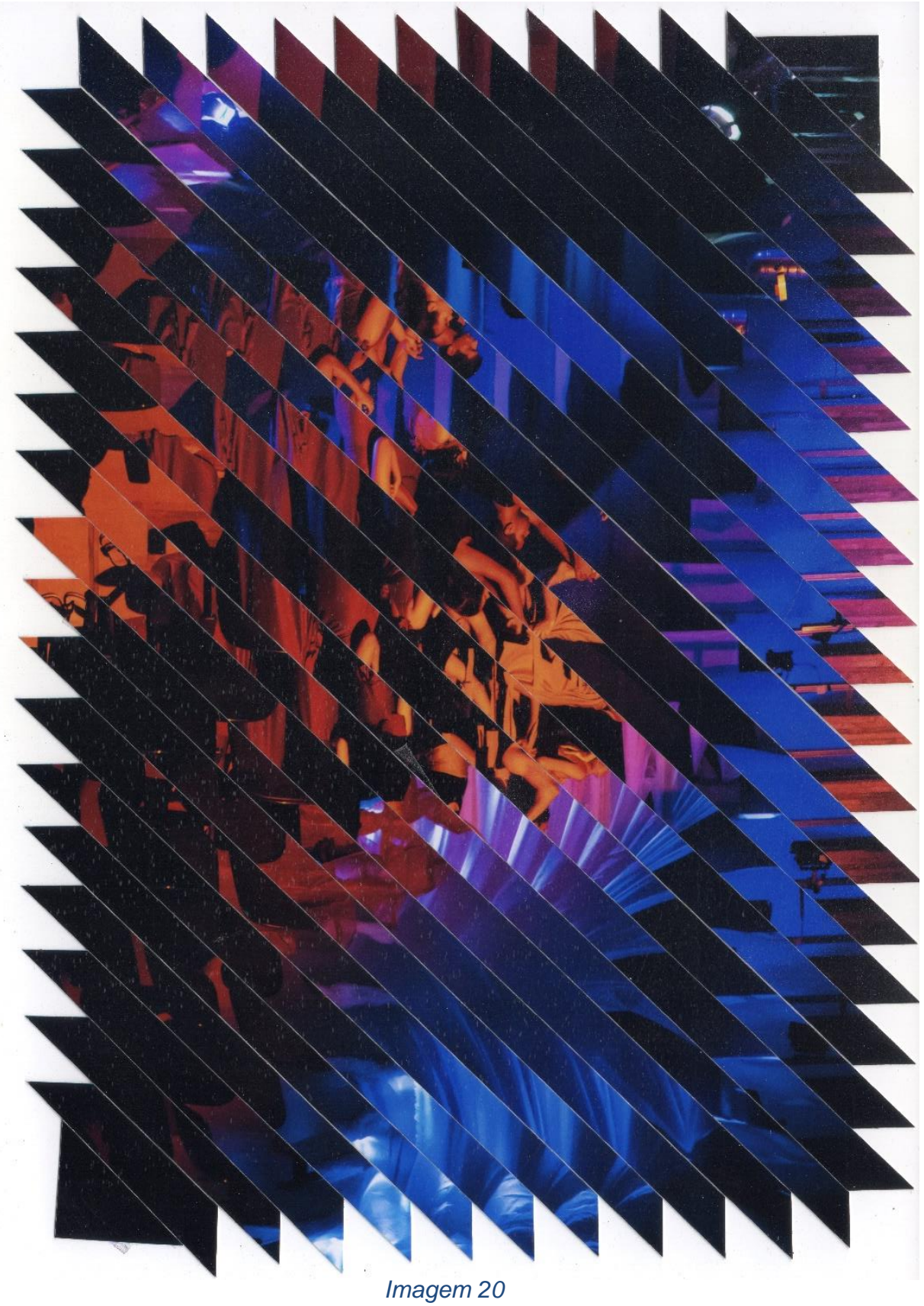


Durante o processo uma outra coisa que também contríbuiu para amenizar o desespero que en estava de trabalhar com isso, foi a possibitidade da construcaio junto com o Paulo, a Marítia, o Westey e o elenco, e da possibitidade de modificacão ao longo do processo. $O$ que me lembra o tipo de pesquisa que a gente se propõe a investigar, de que a estrutura não vem pronta e pode ser movida, mexida e transformada a todo momento (Renata Matsuo).

Os desdobramentos improváveis sobre essa trajetória/percurso/caminho me levaram/fizeram a compreender/considerar que nada é somente uma única coisa. Assim como na (trans)ópera (Maron, 2018). Quando eu, ou qualquer pessoa, dou significados novos ao que é familiar, substituindo o que conheço pelo novo, me liberto do que é esperado e familiar e logo entro no imprevisível, incontrolável. É neste reino do não familiar que encontro novas possibilidades. É no desconhecido que encontro esperança. Parafraseando Paul Klee, eu olho para a forma imposta e só vejo a morte, porque não existe processo, existe uma receita a ser seguida, tanto na vida acadêmica quanto na vida artística. Essa receita tem seu valor e coerência em 
outras investigações (acadêmicas/artísticas), porém, nessa a coerência com o campo me exigiu trazer outra forma.

Me chama atenção, a construcão ser corporal. $O$ que en quero dizer com isso é que a sensaç̃o ou as percepcóes eram anteriores a forma, elas eram anteriores a construção cênica. Então, a partir da escuta da musica, até porque eles são artistas com formacão em canto e a sensacão durante a preparação corporal, é que se construiam as cenas (Renata Matsuo).

Nós vivemos em um mundo que desmerecem as sensações, num mundo que não confia nas experiências. O tempo todo somos lembrados que essas coisas não são tão importantes quanto a razão. Que essas coisas são subjetivas, não mensuráveis, não transferíveis, não universalizáveis (...), somos ensinados a ignora-las, controla-las e/ou nega-los. Nós mal compreendemos o que eles são, de onde vêm (...) como aparecem (...) nós nem sabemos de que maneira pensamos e, ao refletirmos sobre isso, como as coisas que aparecem nos revelam o inesperado. Mas, essas coisas são importantes. Eu tenho e sou o meu corpo ao mesmo tempo.

Antes de transgredir as regras, busquei conhece-las para só depois me livrar delas. Transformar o ordinário em 
extraordinário, aquilo que é do cotidiano que passa desapercebido e colocar luz e foco nele. Quando se pega conceitos diferentes e que as vezes até se excluem, como por exemplo, cantar e dançar ao mesmo tempo para um solista de ópera, junta-se estes, algo hibrido surge, que mais tarde torna-se transgênero. Para mim, o radicalmente qualitativo ao invés de ser uma fraqueza é uma celebração daquilo que é único, singular, irrepetível (...)

De certa forma quando comecei esse projeto, sabia o que me importava, o processo/caminho/método. Mas não sabia qual era a direção e nem qual seria a forma. Mas, eu sabia, que se eu tomasse as decisões, ou seja, fizesse as escolhas lembrando do que me importa, não me importava onde eu chegaria, pois sei que cheguei aonde eu precisava ir. Claro que eu não tinha como prever este trabalho escrito enquanto fazíamos a ópera coreográfica, mas existe uma essência entre 0 processo/método artístico encenado e 0 processo/método escrito.

A ópera tem várias camadas. E são nessas muitas camadas que a sua riqueza da ópera habita. Não é nem o texto, nem a música, nem a dança, mas, sim a ação que está nesta amálgama. A ópera é o teatro da ação na perspectiva do transgênero. 
Passo a entender o que é ópera e como se dá a direção em ópera. Mas, o convite que eu recebi foi para coreografar uma ópera, então como isso se deu? Através desse processo transdisciplinar. Esse processo como um todo, artístico reflexivo, proporcionou turning points pessoais, ou seja, cada integrante envolvido no processo achou seus próprios insights, dando sentidos e significados próprios; e turning points grupais, coisas que foram mais gerais ao grupo. Busquei descrever tudo isso ao longo do trabalho trazendo e conversando com as falas dos autores (livros, artigos, entrevistas, palestras entre outros) e dos autores integrantes do NUO-Ópera Lab. que mais uma vez não são narradores/depoentes/produtores de dados/interlocutores da pesquisa, mas, assinam a autoria desse trabalho comigo.

"Aniversárío e Morte de Queen Mary II" atém de ter sido novo para mim, foi incrivel como participante do processo. compreendi uma coisa que estava muito enraizado em mim, que é a construcão da cena pela estética. A estética que en entendo aqui é a ideía do belo e do que pode ficar bonito tecnicamente, e especialmente, no contexto do baté clássico. Nesse tipo de dança, o que geralmente regem essas construcões são a plasticidade e a forma, e não a sensação 
a construcaio sensitiva do corpo. Por isso que eu acho que o que mais me tirow do eixo, nessa opera, talvez tenha sido experienciar o processo invertido de críacaio. Isso modificou hoje meu processo de críação. Então, a plasticidade, a forma e como é que isso ía ficar naquele espaco, tudo isso foi secundária as sensacóes dos corpos desses artistas. Isso também mexew muito comigo como artista e coreógrafa, acho que isto foi uma das coisas que me modificou (Renata Matsuo).

Fazer pesquisa em um ambiente, como o NUO-Ópera Lab., envolvido com o processo, proporciona todos esses ganhos artísticos, acadêmicos e em pedagogia. Com isso, percebo como o processo é vivo e orgânico e, entendo a pesquisa como um organismo. Portanto aqui foram descortinados: o processo em ópera e o processo de método radicalmente qualitativo. 
Marilia Velardi

15 de junho de 2015

DOMINGO RESERVAS ESGOTADAS

SÁBADO RESERVAS ESGOTADAS

SOLD OUT!!!!!!!

lá pela 5 a feira é bom confirmar com as pessoas ok?

é nóis!!!!

(b) 11

2 comentários Visualizado por 25

Curtir

Comentar

Pedro Ometto Ta bom assim de atingir a meta Paulo Maron?

3 a $\cdot$ Editado $\cdot$ Curtir

(1) 2

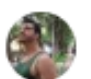

Pedro Ometto

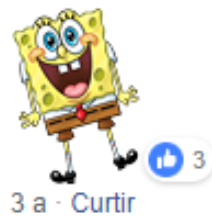

Escreva um comentário.

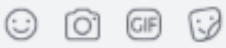

Imagem 21 - Recorte facebook, grupo fechado 
Anexo 1 - Fotografias sem edição, Luciano Osório. 


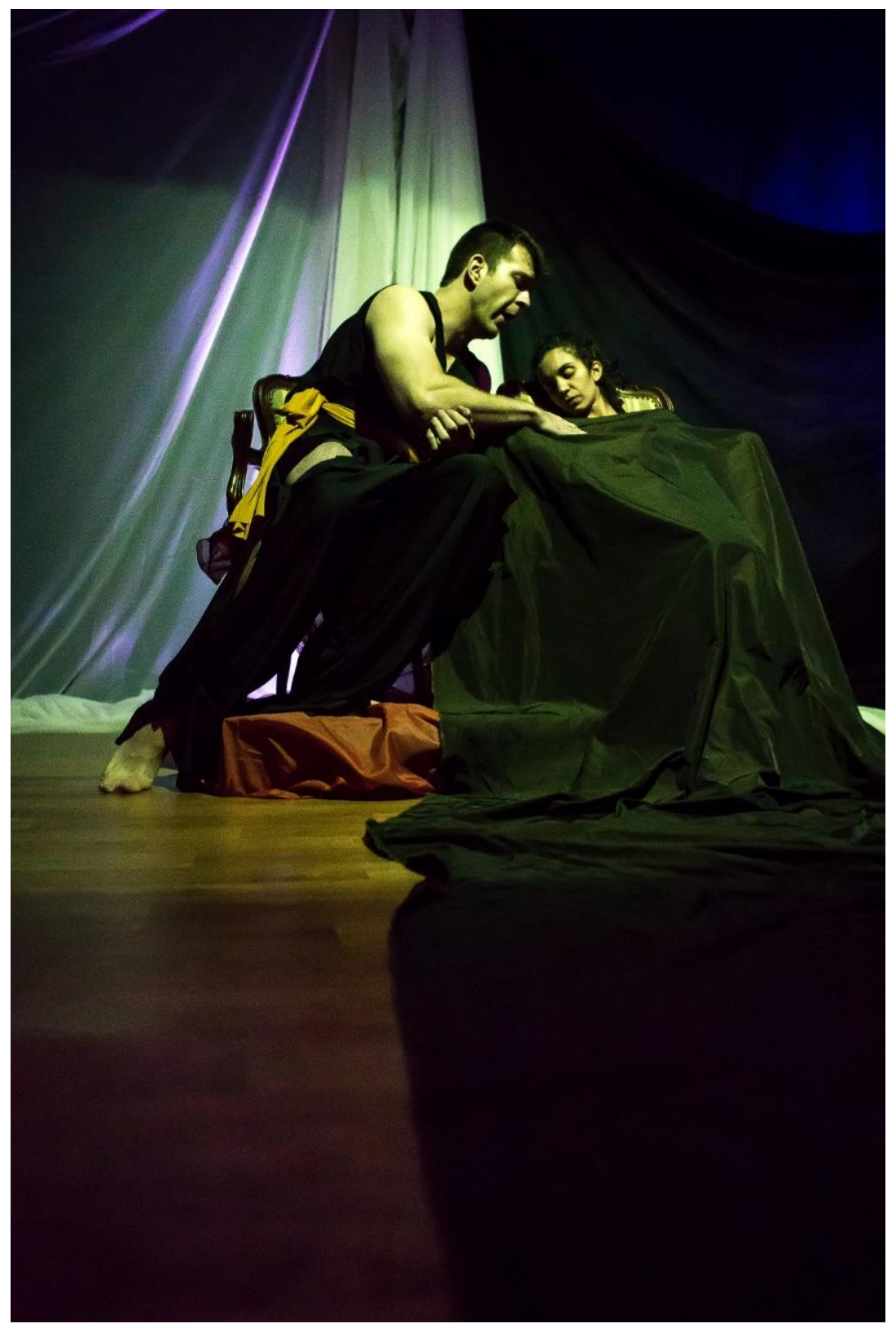

Imagem 22 - Foto by Luciano Osório 


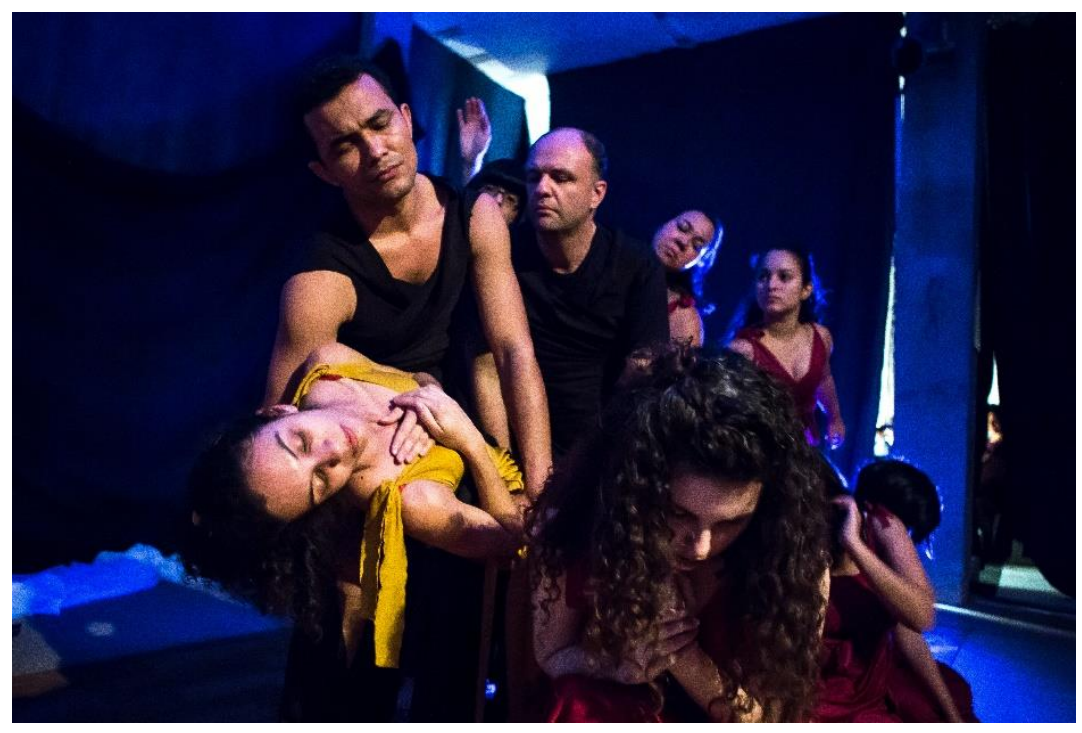




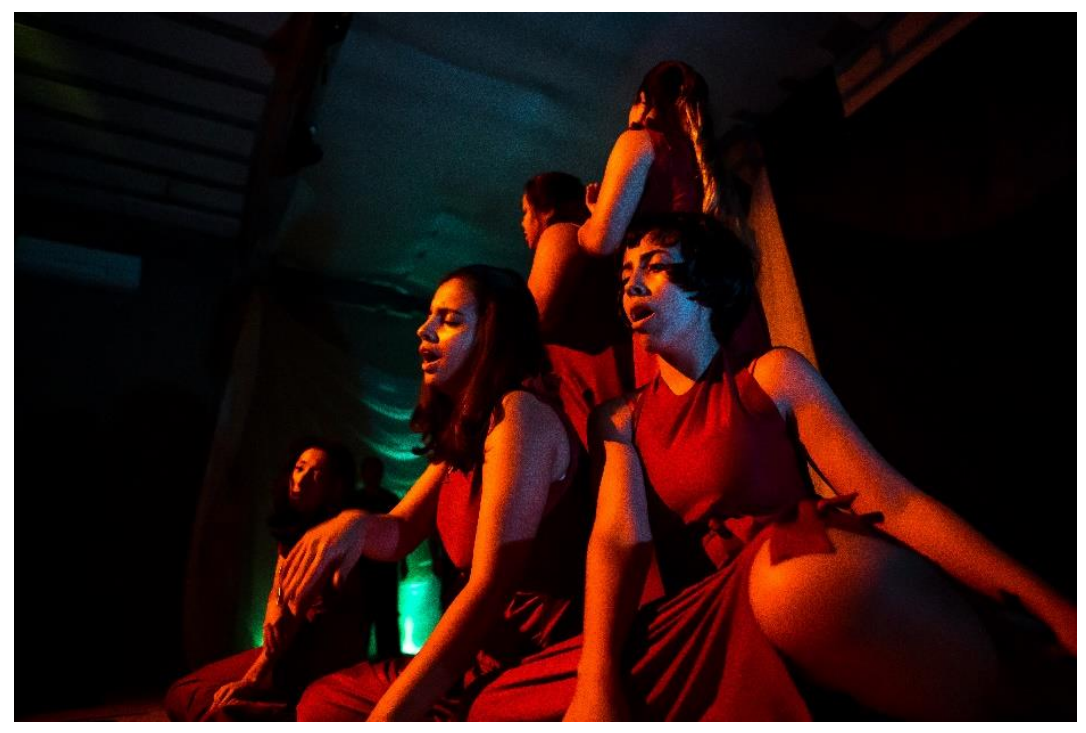




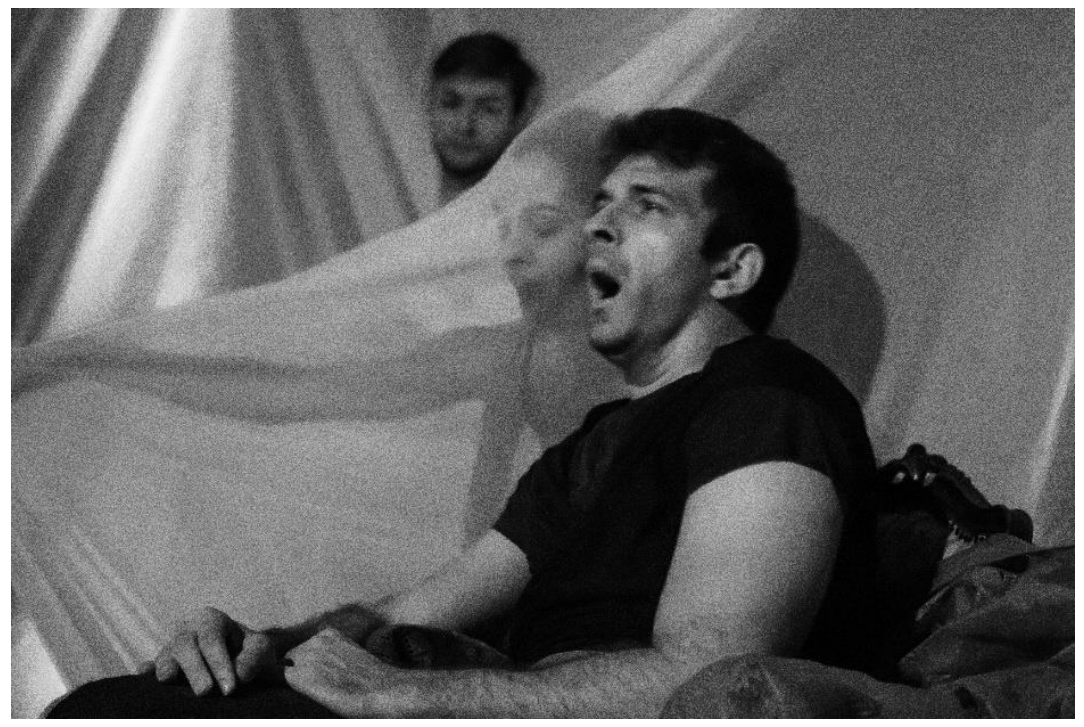




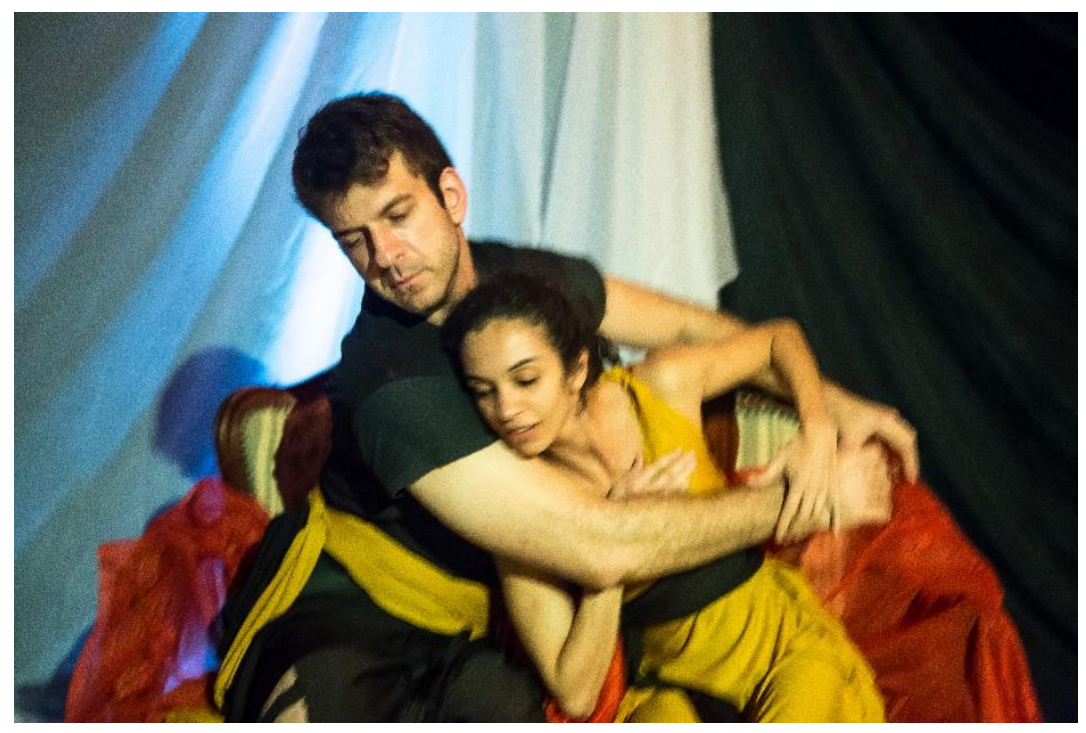




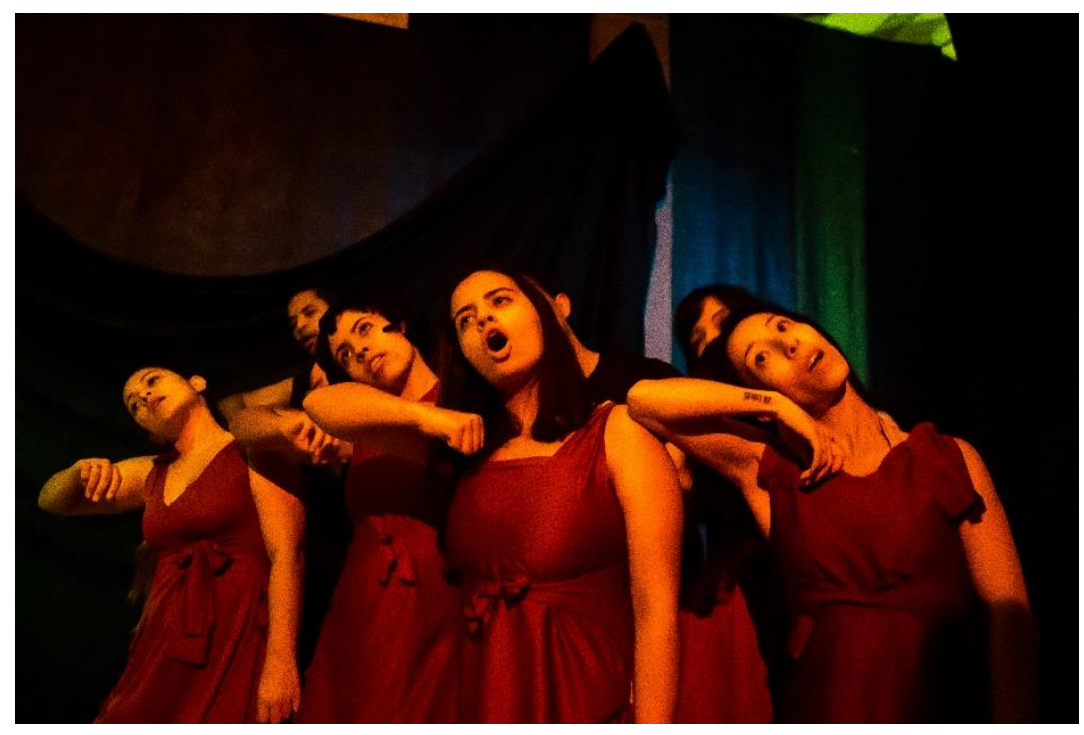




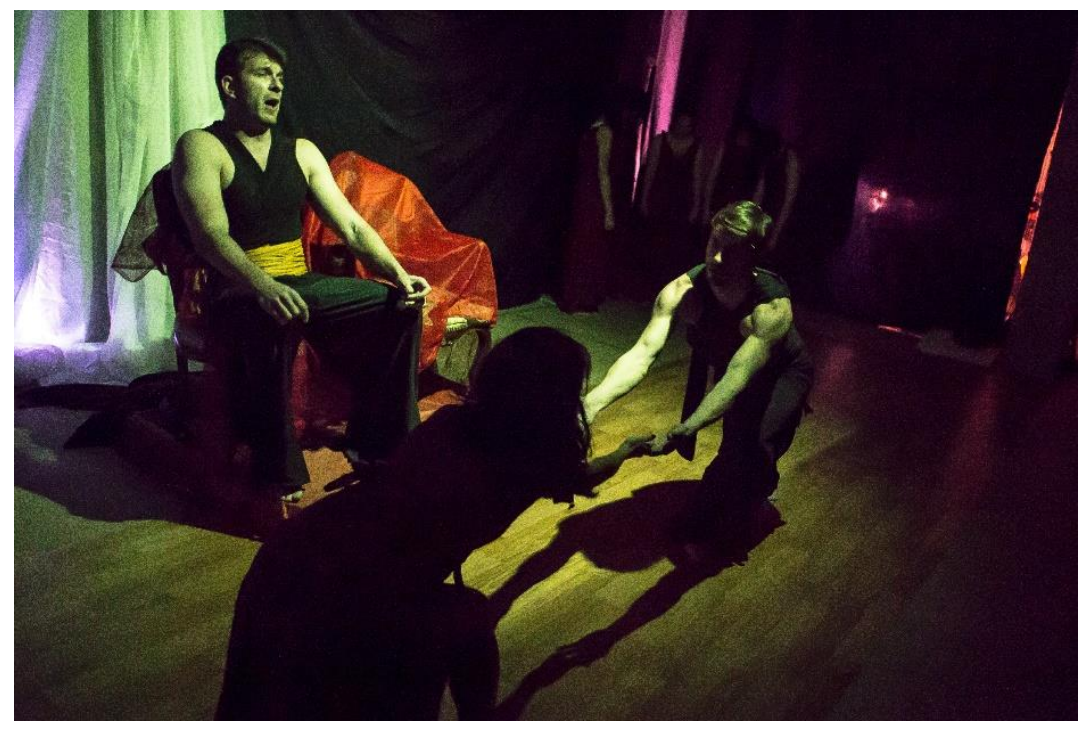




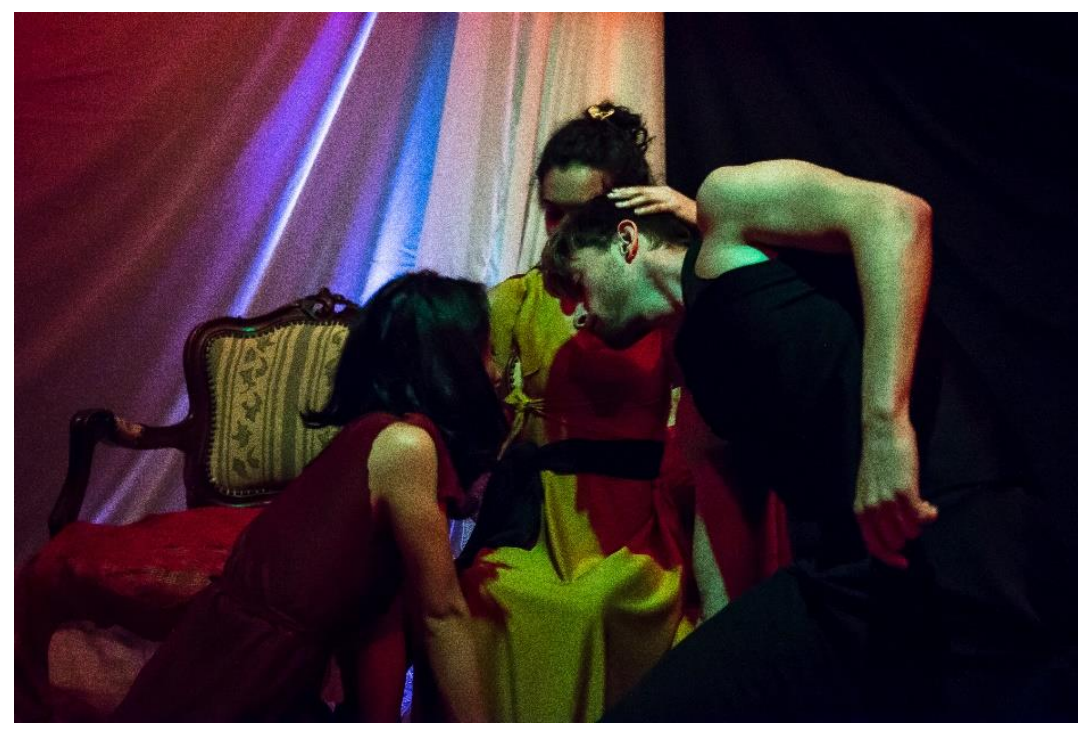




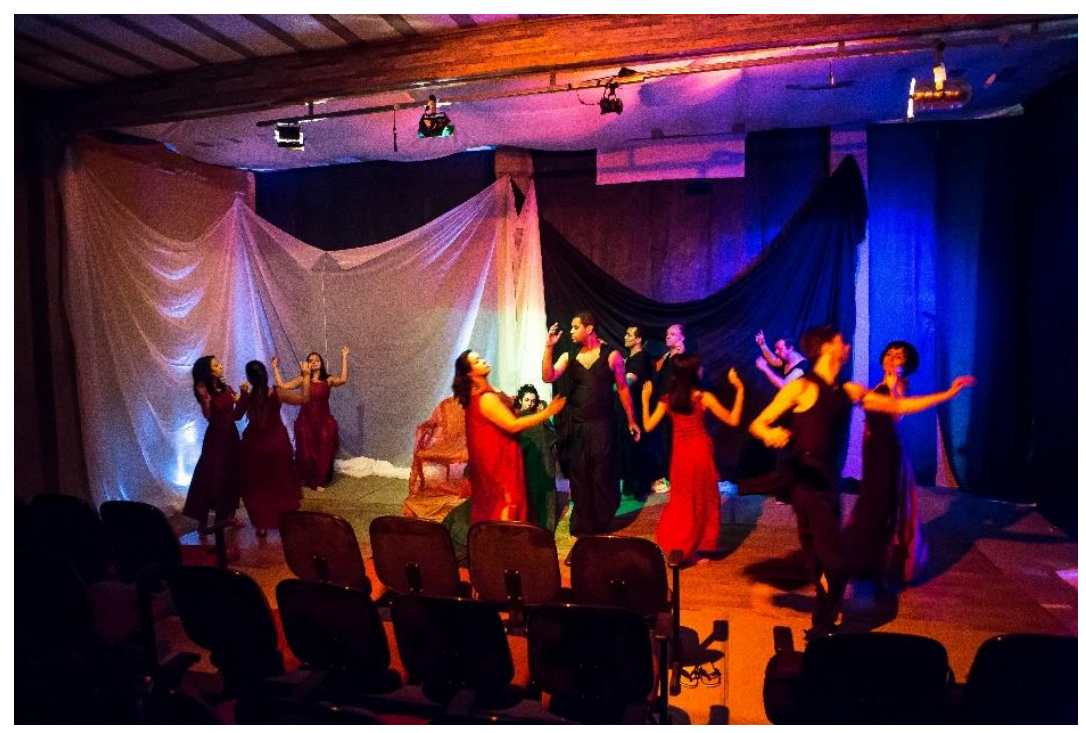




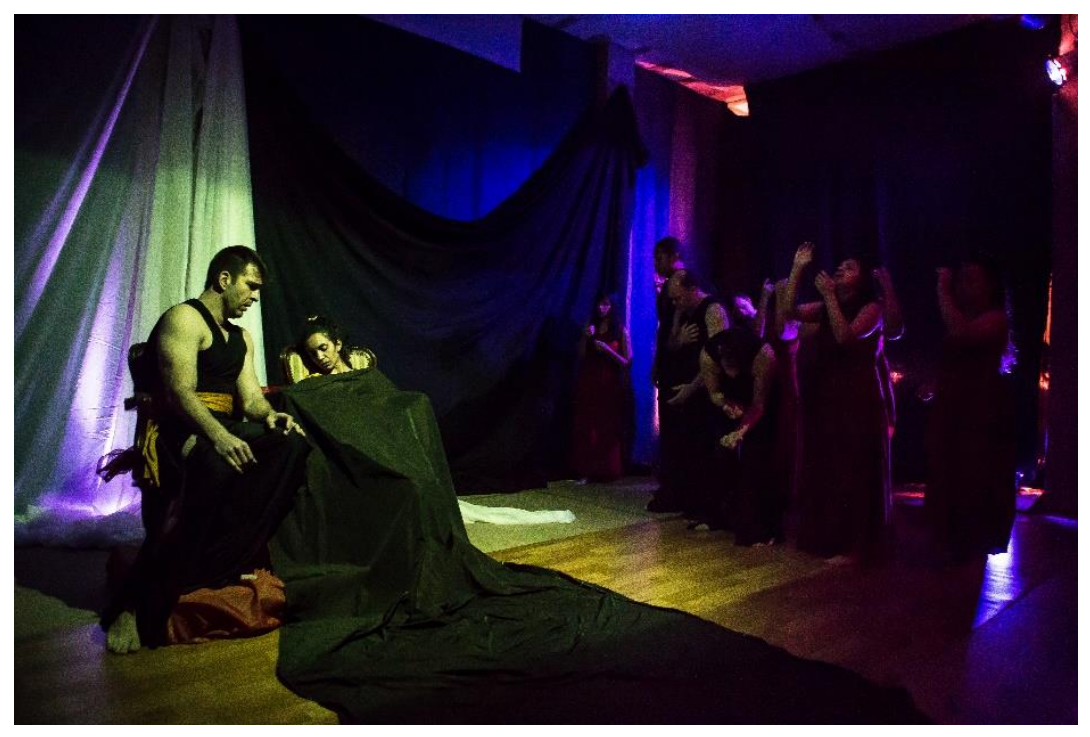




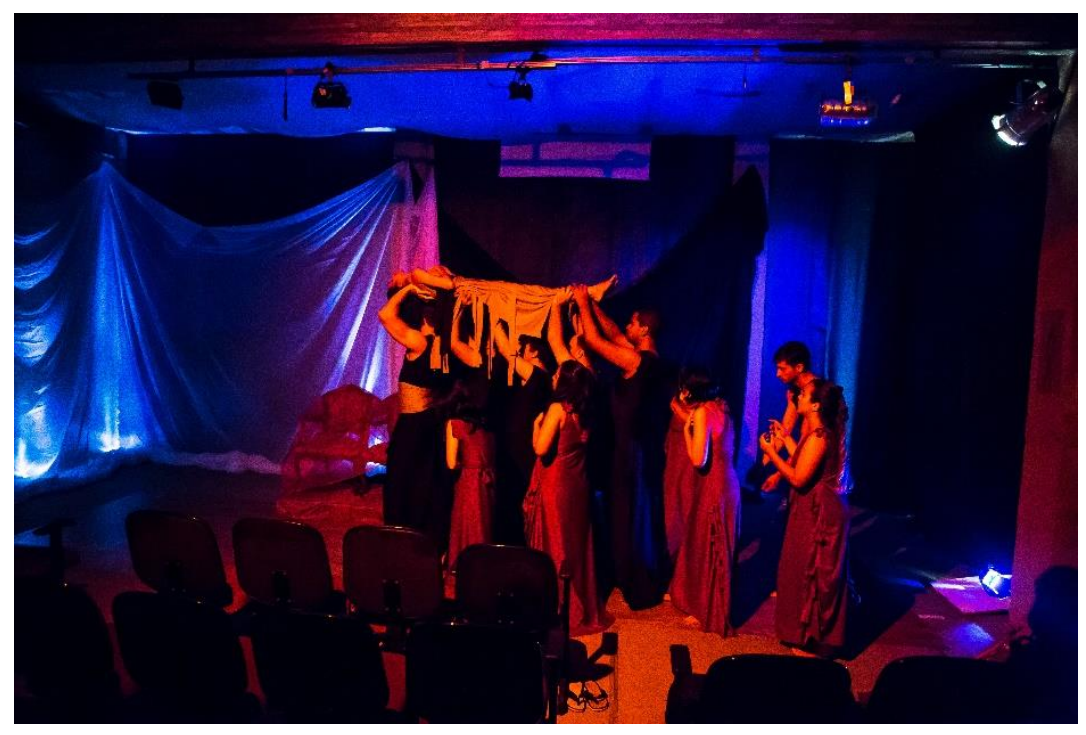




\section{Anexo 2 - Entrevistados}

As biografias citadas aqui, ou foram escritas pelos próprios autores, ou foram retiradas de plataformas, como por exemplo, Lattes.

André Estevez: é cantor, ator, pesquisador e professor de canto, natural de Santos-SP, é mestre em Ciências pela USP no programa Ciências da Atividade Física e Bacharel em Música com habilitação em canto pela UNESP. É integrante do NUO-Ópera Lab. desde 2005, grupo com o qual já participou de inúmeras óperas. Também atua como regente de coros, preparador vocal e encenador, tendo em seu currículo oito espetáculos sob a sua direção, sendo seis óperas e duas peças de teatro musical. Atualmente é professor do programa Guri-Santa Marcelina. Integrante do NUO-Ópera Lab. de 2005 a 2017.

Andrezza Reis: é nascida em São Paulo, tem 22 anos e atualmente cursa Bacharelado em Canto Lírico na Universidade Júlio de Mesquita Filho - UNESP. Iniciou seus estudos em música em 2011 na ETEC de Artes, no curso de Canto Popular. Participou de montagens pelo NUO-Ópera Lab., sob regência e direção de Paulo Maron e preparação de Marília Velardi. Na Fábrica de Óperas, sob orientação do professor e maestro Abel Rocha. Desde 2017, faz parte do 
Coro Acadêmico da OSESP. Integrante do NUO-Ópera Lab. entre 2011 a 2015.

Angélica Menezes: paulista, Bacharel em Música - Canto pelo IA UNESP, Mestra em Música pelo IA UNICAMP e doutoranda em Música também pela UNICAMP. Membro do NUO-Ópera Lab. desde 2010, desenvolve trabalhos cuja premissa é a amálgama de linguagens artísticas. Docente da ETEC de Artes de São Paulo e na Faculdade Mozarteum.

Eliane Florencio Gama: nasceu em 31 de janeiro de 1963, na cidade de Recife, no Estado de Pernambuco. Formou-se em Fisioterapia pela Universidade Federal de Pernambuco. Pós-Doutorado Universidade de São Paulo (2005). Título de Proficiência em Anatomia na Modalidade Humana por Notório Saber pela Sociedade Brasileira de Anatomia (2010). Atualmente é professora e orientadora de mestrado e doutorado na Universidade São Judas Tadeu. Atua no NUOÓpera Lab. desde 2010.

Marília Velardi: Doutora em Pedagogia do Movimento Humano pela UNICAMP. Professora na Escola de Artes, Ciências e Humanidades da Universidade de São Paulo (EACH/USP) nos cursos de graduação em Educação Física e Saúde, no Ciclo Básico e também docente e orientadora no Programa de Pós-Graduação em Mudança Social e 
Participação Política. Na Escola de Comunicações e Artes (ECA/USP) atua como docente no curso de bacharelado em Música e no programa de Pós-Graduação em Artes Cênicas. Como professora e pesquisadora se atenta para as investigações qualitativas e radicalmente qualitativas em Saúde e nas Artes. No campo da saúde os estudos que ela conduz dirigem-se, especialmente, aos programas e intervenção no serviço público de Saúde, na perspectiva do ideário da Promoção em Saúde e na Educação para a autonomia. No campo das Artes propõe intervenções, performances, encenação e projetos de pesquisa e investigação na área artística junto a cantores líricos e instrumentistas, desenvolvendo práticas e estudos sobre preparação corporal para a encenação e criação em ópera. $O$ lócus dessas investigações tem sido o NUO-Ópera Laboratório. Realiza pesquisas colaborativas com grupos do campo da Saúde, da Educação, das Artes da Cena e dos Estudos Sociais. Coordeno o Grupo de Estudo e Pesquisa ECOAR - Estudos em Corpo e Arte. Integrante do NUO-Ópera Lab. desde 2006.

Paulo Maron: maestro, compositor, encenador, cenógrafo e figurinista natural de São Paulo. É doutor pelo CMU da ECAUSP. Mestre em Música pela pelo IA-UNESP (2004), onde desenvolveu estudos sobre as sinfonias compostas por Dmitri 
Shostakovich. Foi professor universitário, atuante nas áreas de orquestração, composição e regência, harmonia e história da arte. Criou e dirigiu orquestras estudantis e dedica-se até hoje à formação de novos músicos. É o fundador e diretor artístico do NUO-Ópera Laboratório que desde 2003 congrega jovens músicos e que já protagonizou mais de 20 montagens operísticas. Construiu o Espaço Núcleo, sede da companhia, local onde atualmente investiga novas possibilidades para a dramaturgia, a composição, a encenação e a adaptação em ópera. Tem desenvolvido estudos e práticas nos campos do teatro de improviso, teatro de animação, teatro Verbatim e nas técnicas relativas à cenografia, figurino e encenação.

Pedro Ometto: nascido em São José dos Campos, estudou no Colégio Koelle em Rio Claro - SP, onde começou a cantar, atuar e dançar (bem de vez em quando). Mais tarde graduouse em música no IA da Unesp de São Paulo, onde conheceu o NUO-Ópera Lab., "grupo com o qual aprendeu as ferramentas para se virar em qualquer palco da Via Láctea". Trabalhou em óperas e musicais pelo Brasil até 2017, ano em que se mudou para Glasgow, onde atualmente faz mestrado em Ópera no Royal Conservatoire of Scotland. Integrante do NUO-Ópera Lab. desde 2004. 
Renata Matsuo: Professora formada em Educação Física pela Universidade São Judas Tadeu (2003), mestrado em Educação Física na Universidade São Judas Tadeu (2007). Atua como pesquisadora da Escola de Artes, Ciências e Humanidades (USP), onde é co-líder do Grupo de Estudo e Pesquisa ECOAR - Estudos em Corpo e Arte. Atua também como docente do Phalibis Studio de Dança, coordenando o curso de dança. Na Universidade Paulista (UNIP) e na Faculdade Drummond, tem orientado os trabalhos de conclusão de curso, bem como lecionado as disciplinas de Ritmo e Dança e Metodologia da Pesquisa. Integrante do NUO-Ópera Lab. desde 2015.

Vanessa Macedo: é coreógrafa, diretora e bailarina da Cia Fragmento de Dança, de São Paulo - SP. Bacharel em Direito pela Universidade Federal do Rio Grande do Norte (1998), mestra em Artes pela Universidade de Campinas (2008) e Doutora em artes cênicas, pela ECA-USP (2016). Iniciou seus estudos em Dança com o Professor Edson Claro, em Natal$\mathrm{RN}$, no grupo de Dança da UFRN, depois de uma atividade de 10 anos como ginasta e técnica de Ginástica Rítmica. Atuou em companhias importantes no cenário nacional e internacional, como a Quasar Cia de Dança, a Cia de Danças de Diadema e a Cia Carne Agonizante. No ano de 2004, estudou dança contemporânea com vários professores, em 
Bruxelas - Bélgica. Atualmente, desenvolve pesquisa sobre dramaturgia em dança e autobiografia nas artes como linguagem cênica.

Yuri Basichetto Tambucci: é Mestre em Antropologia Social pela Universidade de São Paulo, pesquisador associado do Laboratório do Núcleo de Antropologia Urbana (LabNAUUSP). Atualmente é consultor no projeto Cartografia das Territorialidades Culturais do Campo Limpo, da Escola da Cidade, com atividade iniciada em 2016. Possui experiências em pesquisas etnográficas com enfoques relacionados à Antropologia Urbana, como lazer e práticas de sociabilidade, mobilidade, cultura, movimento estudantil e esporte. Artista e violinista no NUO-Ópera Lab. desde 2005. Integrante do NUO-Ópera Lab. desde 2005. 


\section{Referências}

BATTAILLON, V. Orphens und Eurydike (DVD). Paris: Bel Air Classics, 2009.

BECKER, H. Conferência, a escola de Chicago. Mana vol.2 no.2 Río de Janeiro Oct. 1996 Tradução: Vera Pereira

BOLSANELLO, D. P. Em pleno corpo: Educação Somática movimento e saúde. $2^{a}$ ed. Curitiba: Juruá, 2010.

BONDÍA, $J$. L. Sobre a experiência e o saber da experiência. Revista Brasileira de Educação, Jan/Fev/Mar/Abr 2002 no 19.

BOSI, E. Memóría e sociedade: Lembrança dos velhos. 3. ed. São Paulo. Companhia das Letras, 1994.

BOURNE, $J$. Ópera. of grandes compositores e as suas obras-primas. Lisboa: EDITORIAL ESTAMPA, 2008.

BOURNE, J. ÓPERA: of grandes compositores $e$ as suas obras-primas. Lisboa: EDITORIAL ESTAMPA, 2008.

DENZIN, N. K; LINCOLN, Y. S. at all - O planejamento da pesquisa qualitativa. teorias e abordagens. São Paulo: Artmed Bookman, 2010.

DENZIN, N.K. Autoetnografía analitica o nuevo déjà vu. Astrolabio, [S.l.], n. 11, dic. 2013. ISSN 1668-7515. Disponivel em: < https://revistas.unc.edu.ar/index.php/astrolabio/article/view/6310/7398 >. (Acessado em 20/04/2018)

DENZIN, N.K. Re-leyendo Performance, Praxis y Politica. Investigacion Cualitativa. 1(1), pp.58-78, 2016. Disponivel em < 
http://oj8.revistainvestigacioncualitativa.com/index.php/ric $>$ Acessado em: 03/07/2017.

DORT, B. O teatroe a sua reatidade, São Paulo, Perspectivas, 1977.

FARO, A. J. Pequena históría da dança. Río de Janeiro. Jorge Zahar Ed, 1986.

FELDENKRAIS, M. Consciêncíapelomovimento. SãoPaulo. Summus, 1977.

Feldenkrais, M. Mind and body. Your body works. Copyrighted newsletter by Moshe Feldenkrais. p.73-80, 1980. Disponivel em <http://www.feldenkraismethod.com/wp-

content/uploads/2014/11/Mind-and-Body-Moshe-Feldenkrais.pdf $>$ Acessado em 20/02/2018.

GARAUDY, R. Dançar a vída. Río de Janeiro, Nova Fronteira, 1980.

GATTI, P. A expressão dos afetos em peças para cravo de François Coupeirin (1668 -1733). Universidade Estadual de Campinas - Instituto deArtes.

GIGUERE, M. Martha Graham - The Graham Technique. Human kinetics. Excerpts. Disponivel em $<$ http://www.humankinetics.com/excerpts/excerpts/martha-grahamndash-the-graham-techniques Acessado em 19/05/2018.

GOMES, G. A. S. Os afetos musicais no corpo do ator. Florianópolis: Universidade do Estado de Santa Catarina. UDESC; Mestrado;

GRAHAM, M. Memóría do sangue. Tradução Claudia Martinelli Gama. São Pauto. Sícitiano, 1993. 
GREENWOOD, J. Arts-Based Research. Weaving Magic and Meaning. International Journal of Education $E$ TheArts. University of Canterbury, New Zealand v. 13, i. 1 (2012).

HAREWOOD, C. K. O lívro completo da ópera. Rio de Janeiro, JORGE ZAHAR EDITOR, 1997.

INGOLD, T. Trazendo as coisas de volta à vida. Horizontes Antropológicos, Porto Alegre, ano 18, n. 37, pp. 25 -44, jan/jun. 2012.

INGOLD, T.; FIORI, A.L. DIAS DE ANDRADE, J.A.A., TESTA, A.Q.; TAMBUCCI, Y.B. Díalogos Vagueiros. Vída, Movimento e Antropologia (Entrevista com Professor T. Ingold). Ponto Urbe [Ontine], 11 / 2012. Disponivel em: < http:// pontourberevues.org/334 > (Acessado em 17 junho 2016).

INTERNATIONAL FELDENKRAIS FEDERATION. Disponivel em <http://feldenkrais-method.org/en/biography> . Acessado em 12/09/2016.

JONES, S. H. Autoethnography: Making the personal political. In: Norman Denzin e Yvonna S. Lincoin (Eds.), Handbook of Qualitative Research (3rded.). Thousand Oaks, CA: Sage, pp. 763 -92, (2005).

JONES, S. H.; ADAMS, T.; ELLIS, C. Introduction. coming to know autoethnography as more than a method. In Norman Denzine Yvonna S. Lincoln (Eds.) Handbook of autoethnography. Walnut Creek: Left Coast Press, p.17-48, 2013.

KLEE, P. Notebooks, volume 1: the thinking eye. Ed. J. Spitter. London: Lund fumphries, 1961.

KLEE, P. Noteboooks, volume 2: the nature of nature. Trans. H. Norden. Ed. J. Spiller. London. Lund Humphries, 1973. 
LABAN, R. Dominio do Movimento. Ed org. ULMANN, L. São Paulo, Summus, 1978.

LEHMANN, H. Teatropós-dramático. São Paulo: Cosac, 2011.

LEVIN, D. Choreographer's Opera? Bodies, Voices, and Meaning in Pina Bausch's Production of Gluck's 'Orphens and Eurydice'. Mellon School Public Lectures (Vídeo), 2012. Disponivel em <http://www.vimeoinfo.com/video/45141609/davidlevinchoreographers-opera-bodies-voices (Acessadoem 02/12/2017).

LEVIN, D. J. Unsettling opera. Chicago, The Univerty of Chicago Press, 2007.

LEVIN, D. (Edit.) Opera throught other eyes. Stanford: Stanford University Press, 1994.

MACEDO, V. F. P. Arguição na banca de qualíficação. São Paulo, 02 de agosto de 2017.

MACEDO, V. F. P. Pulsação da obra - Dramaturgia nas práticas contemporâneas de dança, 2016. (Tese).

MARON, P. Comunicaçãopessoal. São Pauto, abril de 2013.

MARON, P. NUO Ópera-Lab:: da autoetnografia à trans-ópera. Universidade de São Paulo, 2018. (Tese).

MARON, P; MACHADO, D; VELARDI, M. Ópera coreográfica. experiêncía e possibilidades para dramaturgias do corpo. Revista do Laboratório de Dramaturgia - LADI - UnB - V. 2 e 3, Ano 1. 2017. 
MELO, F. Teoría dos Afetos. Acessado em: 15/04/2017. Disponivel em: <http://historiadamusica2011.blogspot.com.br/2011/07/teoria-dosafetos-teoria-dos-afetos.htmi >

MEYERHOLD, V. Do Teatro. SãoPaulo: Iluminuras, 2012.

MONFORTE, L. G. Fotografia pensante. São Paulo: Senac, 1997.

MONTEIRO, M. Noverre: Cartas sobre a dança. São Paulo, editora da Universidade de São Paulo, 2006.

NOVAES, S.C.; BARBOSA, A.; CUNHA, E.B.; FERRARI, F.; SZTUTMAN, R.; HIKIJI, R.S.G. (Orgs). Escrituras da imagem. São Paulo: EDUSP/Fapesp, 2004.

OLIVARES, L; PEREIRA, S. Trajetórias em Construção: Escritos Cênicos dos Pesquisadores do LAPETT. (Ed.) Prismas, Curitiba, 2016.

PAVIS, P. A encenação contemporânea. Origens, tendências, perspectivas. São Paulo, Perspectivas, 2010.

PEREIRA, S. Rastros do Tanztheater no-Processo Críativo deES-BOÇO. São Paulo, Annablume, 2010.

ROSENFELD, A. Estética e teatro alemão. Ed.1, São Paulo, Perspectiva, 2017.

ROSENFELD, A. Teatro alemão históría e estudos. SãoPaulo, Brasitiense, 1968.

SALDANHA, J. Blue-Collar Qualitative Research, A Rant. Qualitative Inquiry. $V .20$ p.976-980 2014. Disponivel em <https://doi.org/10.1177/1077800413513739> Acessado em 03/07/2018. 
SAMAIN, E. Antropologia, imagens e art. Um percurso reflexivo a partir de Georges Didi-Huberman. Cadernos de Arte e Antropolgia, vol. 3, n 2/2014, pag. 47-55.

TANITCH, R. Mature times. "I am not interested in how people move," said Pina Bausch, "but in what moves them." (Entrevista com Pina Bausch) Disponivel em: <https://www.maturetimes.co.uk/interested-people-movesaid-pina-bausch-moves/ > (Acessado em: 03/02/2018)

VELARDI, M. Arguição na banca de qualíficação. São Paulo, 02 de agosto de 2017.

VELARDI, M. O corpo na ópera. alguns apontamentos. SALA PRETA. V. 11, n. 1 (2011).

VELARDI, M. Questionamentos e propostas sobre corpos de emergência: Reflexóes sobre investigação artistica radicalmente qualitativa, Revista Moringa - Artes do Espetáculo, João Pessoa, UFPB, v.9 n.1 jan/jun 2018 p.43-54.

WALTZ, S. Entwicklung der Choreographischen Oper (The Development of the Choreographic Opera). Disponivel em < https://www. sashawaltz.de/wp-

content/uploads/Choreographische_Oper.pdf > (Acessado em 29/05/2017). 


\section{Sites}

Netflix: Abstract: the art of design. Temporada 1. 2017. $<$ http://netlix.com.br >

Núcleo Universitár io de Ópera < http://nucleodeopera.blogspot.com.br/2010/12/nuo-forever.htmis Pesquisa Qualitativa em Cena $<$ http://pesquisaquatiemcena.blogspot.com/> Pró-Reitoría de Pós-Graduação da Universidade de São Paulo $<\quad$ http://www.prpg.usp.br/index.php/pt-br/apoioadministrativo/legislacao/2015-05-22-21-30-36> 